UNIVERSIDADE DE SÃO PAULO

FACULDADE DE FILOSOFIA, LETRAS E CIÊNCIAS HUMANAS

DEPARTAMENTO DE LETRAS MODERNAS

PROGRAMA DE PÓS-GRADUAÇÃO EM ESTUDOS LINGUÍSTICOS E LITERÁRIOS EM INGLÊS

FABIANO FLEURY DE SOUZA CAMPOS

A subversão da forma em duas peças de Mark Ravenhill

Versão final

São Paulo

2020 
UNIVERSIDADE DE SÃO PAULO

FACULDADE DE FILOSOFIA, LETRAS E CIÊNCIAS HUMANAS

DEPARTAMENTO DE LETRAS MODERNAS

PROGRAMA DE PÓS-GRADUAÇÃO EM ESTUDOS LINGUÍSTICOS E

LITERÁRIOS EM INGLÊS

\section{A subversão da forma em duas peças de Mark Ravenhill}

Fabiano Fleury de Souza Campos

Tese apresentada ao Programa de PósGraduação em Estudos Linguísticos e Literários em Inglês do Departamento de Letras Modernas da Faculdade de Filosofia, Letras e Ciências Humanas da Universidade de São Paulo para a obtenção do título de doutor em Letras.

O presente trabalho foi realizado com apoio da Coordenação de Aperfeiçoamento de Pessoal de Nível Superior - Brasil (CAPES) - Código de Financiamento 001.

Orientadora: Profa. Dra. Mayumi Denise Senoi Ilari

Versão final

São Paulo

2020 
Autorizo a reprodução e divulgação total ou parcial deste trabalho, por qualquer meio convencional ou eletrônico, para fins de estudo e pesquisa, desde que citada a fonte.

Catalogação na Publicação

Serviço de Biblioteca e Documentação

Faculdade de Filosofia, Letras e Ciências Humanas da Universidade de São Paulo

C198s A subversão da forma em duas peças de Mark Ravenhill / Fabiano Fleury de Souza Campos ; orientadora Mayumi Denise Senoi Ilari. - São Paulo, 2020 .

$147 \mathrm{f}$.

Tese (Doutorado)- Faculdade de Filosofia, Letras e Ciências Humanas da Universidade de São Paulo. Departamento de Letras Modernas. Área de concentração: Estudos Linguísticos e Literários em Inglês.

1. Ravenhill, Mark (1966). 2. Teatro britânico, final do século Xx. 3. Teatro in-yer-face. I. Ilari, Mayumi Denise Senoi, orient. II. Título. 


\section{ENTREGA DO EXEMPLAR CORRIGIDO DA DISSERTAÇÃO/TESE}

\section{Termo de Ciência e Concordância do (a) orientador (a)}

\section{Nome do (a) aluno (a): Fabiano Fleury de Souza Campos}

Data da defesa: 24/04/2020

Nome do Prof. (a) orientador (a): Mayumi Denise Senoi Ilari

Nos termos da legislação vigente, declaro ESTAR CIENTE do conteúdo deste EXEMPLAR CORRIGIDO elaborado em atenção às sugestões dos membros da comissão Julgadora na sessão de defesa do trabalho, manifestando-me plenamente favorável ao seu encaminhamento e publicação no Portal Digital de Teses da USP.

São Paulo, 02/06/2020

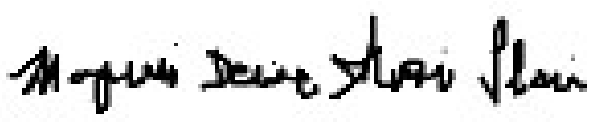




\section{Resumo}

Esta tese analisa as peças Shopping and Fucking e Pool (no water), do dramaturgo britânico Mark Ravenhill (1966- ). O nosso objetivo se volta mais especificamente para a análise pormenorizada da forma dramatúrgica na passagem de uma peça para a outra, o que se associa a um estado de degeneração crescente das relações sociais retratadas. Extremamente agressiva, a primeira peça, escrita em 1996, fala deliberadamente sobre a vida de quatro jovens e um adulto voltados para o consumismo, marca a estreia do dramaturgo e permanece sendo a mais conhecida de sua carreira, recebendo inúmeras montagens e encenações em diversas partes do mundo, inclusive no Brasil. A segunda obra, escrita dez anos mais tarde, marca um momento de radicalização maior da forma. Comparativamente menos conhecida do que a primeira, os seus temas são menos explícitos e se desenvolvem a partir da relação de amizade entre um "grupo" de amigos do qual faz parte uma fotógrafa famosa. Apoiando-nos nas análises de críticos teatrais como Peter Szondi, Jean-Pierre Sarrazac, Renata Pallottini, Jean-Jacques Roubine e JeanPierre Ryngaert, procuramos tratar, sobretudo, das transformações estruturais envolvendo a configuração dos diálogos e dos personagens, sofridas nessas peças, assim como das relações/contradições envolvendo a forma e o conteúdo em ambas as obras. Em seguida, ampliamos as discussões relacionando questões estruturais a temas como a massificação, a corporeidade e a pauperização da arte no mundo contemporâneo, segundo estudos de Roswhita Scholz, Walter Benjamin, Fredric Jameson, entre outros. Ao longo deste trabalho dialogamos também com estudiosos das artes cênicas mais voltados para o teatro britânico da virada do último milênio, como Alekz Sierz e Dan Rebellato. Ao final, observamos como a radicalização das formas resultando em configurações incomuns tanto dos personagens quanto dos diálogos se relaciona com a exposição de indivíduos cada vez mais fragmentados na estrutura de uma vida social cada vez mais agonizante.

Palavras-chave: Ravenhill, Mark (1966); teatro britânico, final do século XX; Teatro inyer-face. 


\begin{abstract}
This thesis analyzes the plays Shopping and Fucking and Pool (no water), written by British playwright Mark Ravenhill (1966- ). Our goal focuses more specifically on a detailed formal analysis associated with the passage from the former to the later play and a state of increasing degeneration of the portrayed social relations. Extremely aggressive, the first play, written in 1996, deliberately deals with the lives of four young people and an adult. Centered on the act of consumerism, this play marks Ravenhill's debut and remains as the best-known work of his career, being staged and adapted in various parts of the world, including Brazil. The second work, written ten years later, marks a greater radicalization of the play's form. Comparatively less known than the first play, its themes are less explicit and develop from the relationship between a "group" of friends and a famous photographer. Relying on the analyses of theatrical critics such as Peter Szondi, Jean-Pierre Sarrazac, Renata Pallottini, Jean-Jacques Roubine and Jean-Pierre Ryngaert, among others, our study firstly deals with structural changings related to the configuration, mainly, of dialogues and characters, found in these plays, as well as the relations/contradictions involving form and content in both works. Then, these discussions relating structural issues are expanded to topics such as massification, corporeality and pauperization of art in the contemporary world, based on the analyses of Roswhita Scholz, Walter Benjamin, Fredric Jameson and others. Throughout this work, we also dialogue with performing arts scholars more focused on the British theatre enacted during the turn of the last millennium, such as Alekz Sierz and Dan Rebellato. In the end, this research analyzes the radicalization of forms resulting mainly in unusual configurations of both characters and dialogues as related to the exposure of increasingly fragmented individuals to a more and more agonizing social life structure.
\end{abstract}

Keywords: Ravenhill, Mark (1966); In-yer-face theatre; British theatre, late 20th century. 


\section{Agradecimentos}

À orientadora desta pesquisa, Professora Mayumi Denise Senoi Ilari, pelo apoio integral e irrestrito - esta tese nunca teria existido não fosse por ela. Às professoras Elen de Medeiros, da Universidade Federal de Minas Gerais, e Maria Elisa Cevasco, da Universidade de São Paulo, que, além de participarem da banca de qualificação, também estiveram presentes na banca julgadora, pela leitura atenta e pelas sugestões que muito nos auxiliaram. À professora Andrea Copeliovitch, da Universidade Federal Fluminense, por participar da comissão examinadora, pelos comentários e críticas sempre pertinentes. Ao apoio da Coordenação de Aperfeiçoamento de Pessoal de Nível Superior - Brasil (CAPES) - Código de Financiamento 001 e ao Programa de Pós-graduação em Estudos Linguísticos e Literários em Inglês, DLM/USP, pela bolsa de estudos cujos benefícios se estenderam quase inteiramente pelo período desta pesquisa.

Ao Professor Daniel Puglia - Coordenador da Pós-Graduação em Estudos Linguísticos e Literários em Inglês - e à Professora Lenita Maria Rimoli Esteves - Chefe do Departamento de Letras Modernas -, que gentilmente autorizaram a concessão do apoio financeiro, via PROAP e verba de internacionalização, para viagem de pesquisa à Universidade de Surrey, na Inglaterra, realizada em janeiro de 2019.

Ao Professor Bran Nicol, Chefe do Departamento de Línguas e Literatura na Universidade de Surrey, que solicitamente nos recebeu em sua instituição. À Professora Ana Cláudia Suriani, do Departamento de Estudos Brasileiros, na Universidade College London, e ao Professor John Milton, do Departamento de Estudos Linguísticos e Literários em Inglês, na USP/FFLCH, pelos contatos valiosos na Inglaterra. À Professora Ida Sedler, de Teatro e Performance, da Universidade de Londres/Birkbeck, na Inglaterra, pela troca contínua de ideias sobre teatro contemporâneo. 
A João Alves e Rodrigo Campos pelas inúmeras leituras, discussões e revisões deste trabalho, assim como às revisoras Maria Meller e Natália Jung. À Emília Augusta pelos comentários precisos e esclarecedores sobre as obras de Freud e Lacan relacionadas a este trabalho. À Myriam Fleury e ao Rafael Fleury pelo apoio incondicional e permanente. À Dirce Maria por suas inspirações artísticas contagiantes. À Evelise Rezzaghi pela diagramação desta tese, assim como pela paciência, a força, o carinho, o apoio e o companheirismo imensuráveis. 


\section{Sumário}

1. Introdução

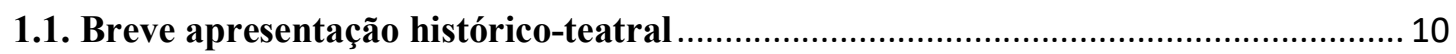

1.2. O dramaturgo Mark Ravenhill, a sua carreira e as peças Shopping and Fucking e

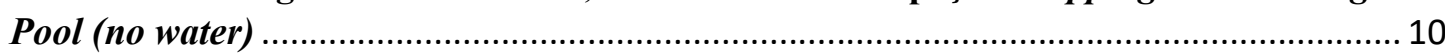

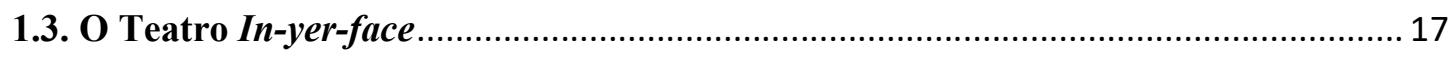

1.4. A geração dos filhos de Margaret Thatcher ........................................................... 19

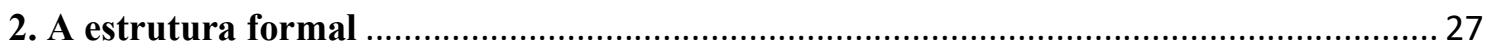

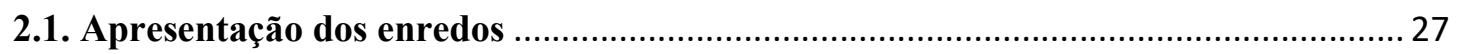

2.1.1. A repetição do enredo em Shopping and Fucking ………..................................... 28

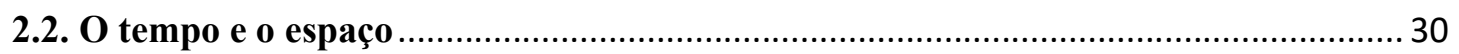

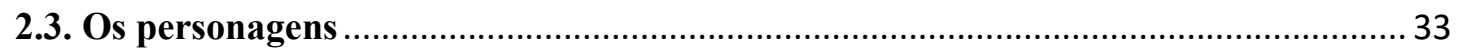

2.3.1. Apresentação dos personagens em Shopping and Fucking …………................. 33

2.3.1.1. O limite dos "personagens" em Shopping and Fucking .................................. 39

2.3.1.2. A influência da figura paterna sobre os personagens de Shopping and Fucking

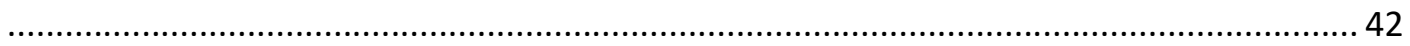

2.3.2. Apresentação dos "personagens-letra” em Pool (no water) .................................. 46

2.3.2.1. O limite dos "personagens-letra" em Pool (no water) ...................................... 49

2.3.2.2. A personagem ausente e a narrativa em Pool (no water) .................................. 54

2.3.3. Afinal, quem são os personagens de Mark Ravenhill? ....................................... 62

2.4. A quebra de ilusão nos cenários de Shopping and Fucking e Pool (no water)........... 65

2.5. A transformação dos diálogos em Shopping and Fucking e Pool (no water)............ 67

2.5.1. As "estorinhas" em meio aos diálogos de Shopping and Fucking ....................... 69

2.5.2. O diálogo voltado para o passado em Pool (no water)........................................ 76

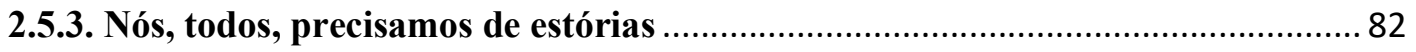

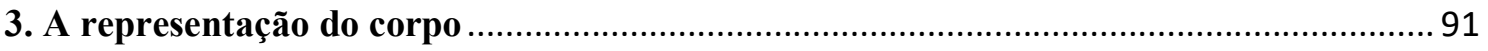

3.1. O corpo que não sente em Shopping and Fucking ….............................................. 93

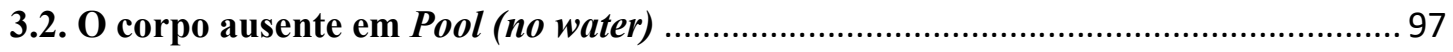

3.3. Considerações sobre a montagem do Frantic Assembly ......................................... 103

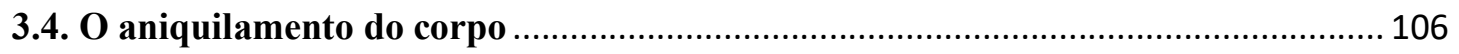

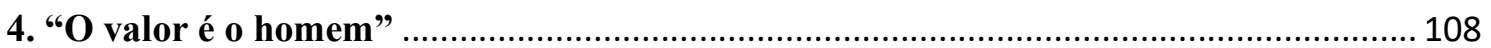

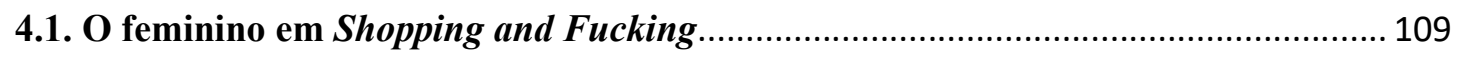

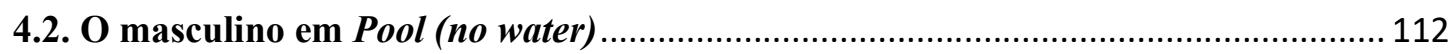

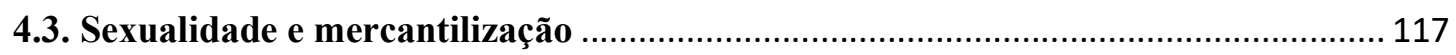

4.4. Shopping and Fucking e Pool (no water): entre Gay e Queer ................................. 123 
5. Considerações finais: Teatro In-Yer-Face, liberalismo e sociedade 128

5.1. A predominância dos temas e a subversão das formas 130

Referências 136 


\section{Introdução}

Este trabalho objetiva mostrar como a degradação contínua da vida social vista nas peças Shopping and Fucking e Pool (no water) implica a radicalização contínua também da forma dramatúrgica, com base na análise e comparação feita entre uma e outra peça de Mark Ravenhill. Trata-se de analisar um processo que, na Inglaterra, a partir da era Thatcher, segue em ritmo acelerado: a vitória do neoliberalismo e as suas consequências sociais ${ }^{1}$, num movimento próprio do mundo "globalizado" e que ocorre de maneira cada vez mais excludente e capaz de reproduzir a marginalização e a desagregação social em grande escala. ${ }^{2}$

Esta tese se inicia com uma apresentação histórico-teatral relacionada ao dramaturgo Mark Ravenhill, à sua carreira e às peças Shopping and Fucking e Pool (no water). Em seguida, tratamos do movimento intitulado na Inglaterra de In-yer-face e do governo de Margaret Thatcher. A análise da estrutura formal dessas duas peças de Ravenhill compõe o segundo capítulo cujos subtópicos versam sobre enredo, personagem e diálogo, assim como cenário, tempo e espaço. A massificação, a sexualidade e a pauperização das obras de arte no universo das duas peças compõem os temas dos capítulos seguintes. No final, nossas considerações se direcionam para a predominância dos temas e a subversão das formas em ambas as peças.

\footnotetext{
${ }^{1}$ Cf. PEACOCK, K. D. Thatcher's Theatre: British Theatre and Drama in the Eighties. Londres: Greenwood Press, 1999.

${ }^{2}$ Cf. KURZ, R. O colapso da modernização: da derrocada do socialismo de caserna à crise da economia mundial. São Paulo: Paz e Terra, 1996.
} 


\subsection{Breve apresentação histórico-teatral}

A seguir procuramos apresentar uma visão pontual sobre o dramaturgo e o contexto histórico relacionado às peças analisadas neste trabalho. Por isso, tratamos também do movimento teatral que se tornou conhecido como In-yer-face e do governo de Margaret Thatcher na Inglaterra, sobretudo, no que diz respeito às políticas públicas no âmbito da cultura e aos seus reflexos sentidos no universo das artes cênicas daquele período.

\subsection{O dramaturgo Mark Ravenhill, a sua carreira e as peças Shopping and Fucking e Pool (no water)}

Possivelmente o dramaturgo mais importante da sua geração na Inglaterra, as suas peças denunciam a ganância e o consumismo típicos dos dias atuais, chacoalhando os seus espectadores por meio de imagens cênicas chocantes e violentas. Nascido em 1966 na cidade de West Sussex, surgiu não apenas como um dos dramaturgos mais provocativos da sua geração, mas também como uma figura central entre os novos escritores do teatro contemporâneo inglês.

Estudante de inglês e artes cênicas na Universidade de Bristol, mudou-se posteriormente para Londres, onde primeiro trabalhou como assistente administrativo no Teatro Soho Poly e, então, como ministrante de workshops entre 1989 e 1991. Em 1993, Ravenhill escreveu sua primeira peça, Close to You, uma comédia sobre um membro do parlamento que tem sua homossexualidade revelada publicamente ${ }^{3}$.

\footnotetext{
${ }^{3}$ Essa introdução biográfica baseou-se principalmente no In-Yer-Face Theatre: British Drama Today (p. 122-152) de Aleks Sierz e no Methuen Drama Guide to Contemporary British Playwrights (p. 403-424) nas análises feitas por Caridad Svitch.
} 
Em 2002, Ravenhill foi indicado como diretor artístico do Teatro Nacional da Inglaterra e é atualmente crítico de cultura do jornal londrino "The Guardian". De todos os artistas que conquistaram notoriedade com o movimento intitulado In-yer-face, Ravenhill tem, segundo o crítico inglês Aleks Sierz (2000, p. 41), mantido a carreira mais diversificada não só como dramaturgo mas, também, como crítico e ativista das artes cênicas. Até o momento, são três volumes publicados contendo, somadas, 15 peças.

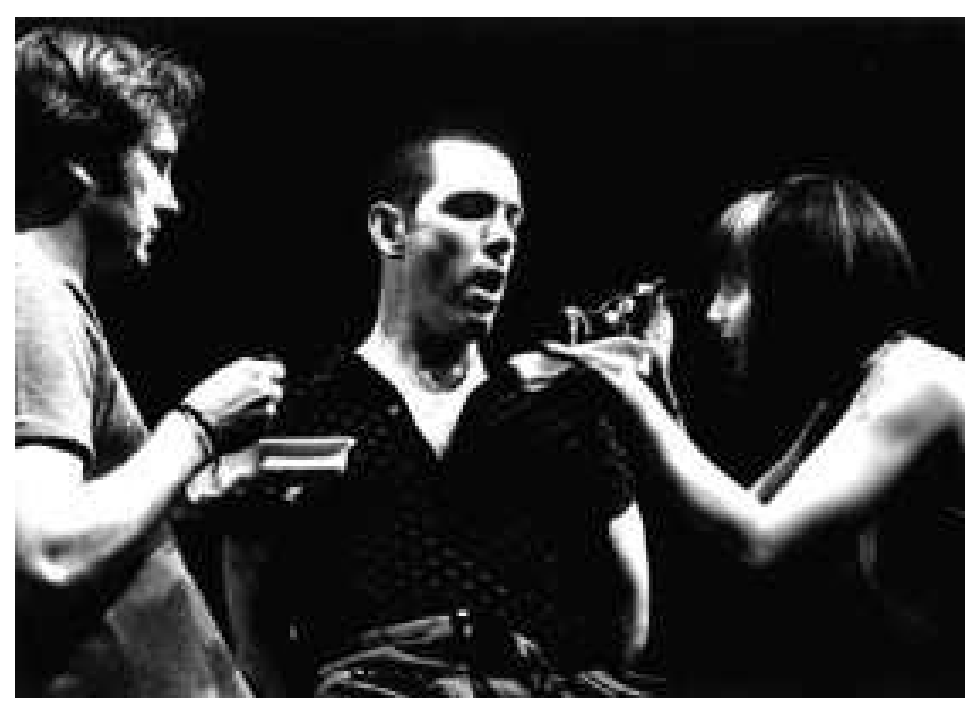

Atores em cena na montagem da peça Shopping and Fucking em Londres, Inglaterra, 1996. Disponível em http://www.outofjoint.co.uk/prods/s and f.html. Acesso em 10 de julho, 2016.

Shopping and Fucking, sua peça de estreia, é tida como a mais conhecida e marcante de sua geração aos olhos dos espectadores, dos críticos e acadêmicos ingleses ${ }^{4}$. E marca um ponto de virada no teatro britânico, sendo responsável por atrair às salas de espetáculo um público mais jovem e pouco habituado ao teatro, revitalizando a cena londrina.

Quando estreou no Teatro Royal Court, em uma produção realizada pela companhia de teatro britânica Out of joint, na cidade de Londres, no ano de 1996, a

\footnotetext{
${ }^{4}$ O crítico Aleks Sierz (2008, p. 23) afirma que, "desde a sua estreia, Shopping and Fucking se transformou num texto canônico dos anos 1990, influenciando outros dramaturgos e recebendo aprovação acadêmica".
} 
comoção causada decorreu dos temas e da linguagem considerados obscenos e também por causa do seu título que, devido à lei inglesa chamada Indecent Advertisement Act, de 1898, passou a ter de se intitular Shopping and $F^{* * * i n g, ~ p e r m a n e c e n d o ~ i n a l t e r a d o ~ n a ~}$ Inglaterra até os dias de hoje $\mathrm{e}^{5}$. Ironicamente, a censura acabou deixando a peça ainda mais atraente e famosa, de modo que, num breve espaço de tempo, passou a circular por outras cidades da Inglaterra a fim de, em seguida, receber montagens em diversos países da Europa, dos EUA e, então, da Austrália e da América Latina, chegando, também, ao Brasil.

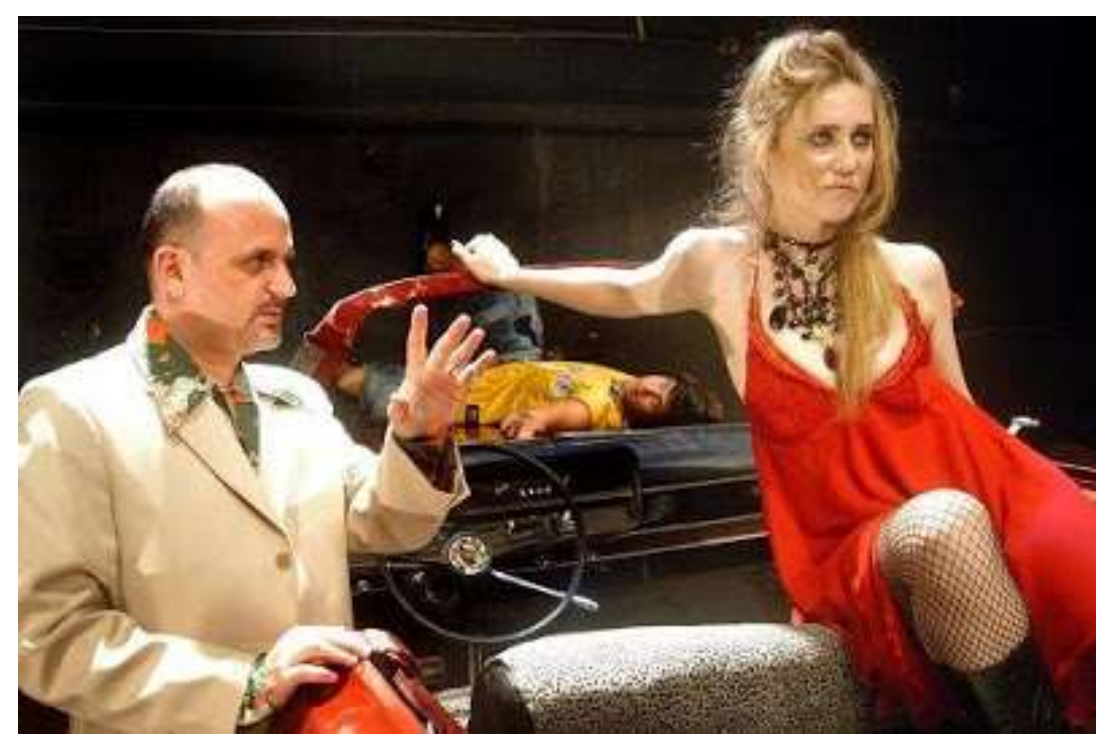

Atores em cena da peça $S F$ na montagem realizada em Salvador, Bahia, 2007. Disponível em http://shopping-and-fucking.blogspot.com.br/. Acesso em 10 de julho, 2014.

Encenada em 1999 na cidade de São Paulo, Shopping and Fucking teve direção de Marco Ricca. Em entrevista para o jornal "Folha de São Paulo" (1999), o diretor comenta sobre a recepção da peça: "Hoje em dia o jovem tem acesso fácil a uma grande quantidade de informação. Mas, ao mesmo tempo, vive uma crise de falta de perspectiva, de comunicação. Não sabe o que fazer". Nos ensaios abertos, realizados no final de

\footnotetext{
${ }^{5}$ SIERZ, 2000, p. 125.
} 
semana anterior à estreia, Ricca revelou ter havido, por um lado, muita procura e falta de espaço para tantos espectadores interessados e, por outro, uma considerável evasão de pessoas que, segundo ele, "teriam visto uma realidade que preferem ignorar" ${ }^{\text {. O }}$ apelo comercial e a divulgação atraíram um público que parecia disposto a vivenciar uma experiência estética distinta. O título funcionava como chamariz. Todavia, o tom de agressividade e de provocação, segundo o diretor, fugia do habitual e era recebido como uma ofensa proporcionalmente maior que a disposição do público a enfrentá-la.

Em 2007, a peça foi montada novamente no país, dessa vez em Salvador, sob a direção de Fernando Guerreiro. Segundo as informações disponibilizadas no blog "Shopping and Fucking", coordenado pela atriz do elenco Jussilene Santana, a repercussão do espetáculo acabou levando o diretor e os atores a muitos encontros e debates com alunos universitários de instituições da cidade, como os ocorridos na Universidade Federal da Bahia ${ }^{7}$. Em 2009, o mesmo elenco participou do Festival de Teatro Brasileiro, sediado em Recife, antes de excursionarem por outras regiões do país.

Ambas as montagens optaram por manter o título original em inglês sem cortes, o que revela, por um lado, a desobediência à censura britânica e, por outro, uma certa indisposição de lidar com o título e a sua tradução para o português.

\footnotetext{
${ }^{6}$ Cf. RAGAZZI, 1999.
}

${ }^{7}$ Cf. SANTANA, 2007. 


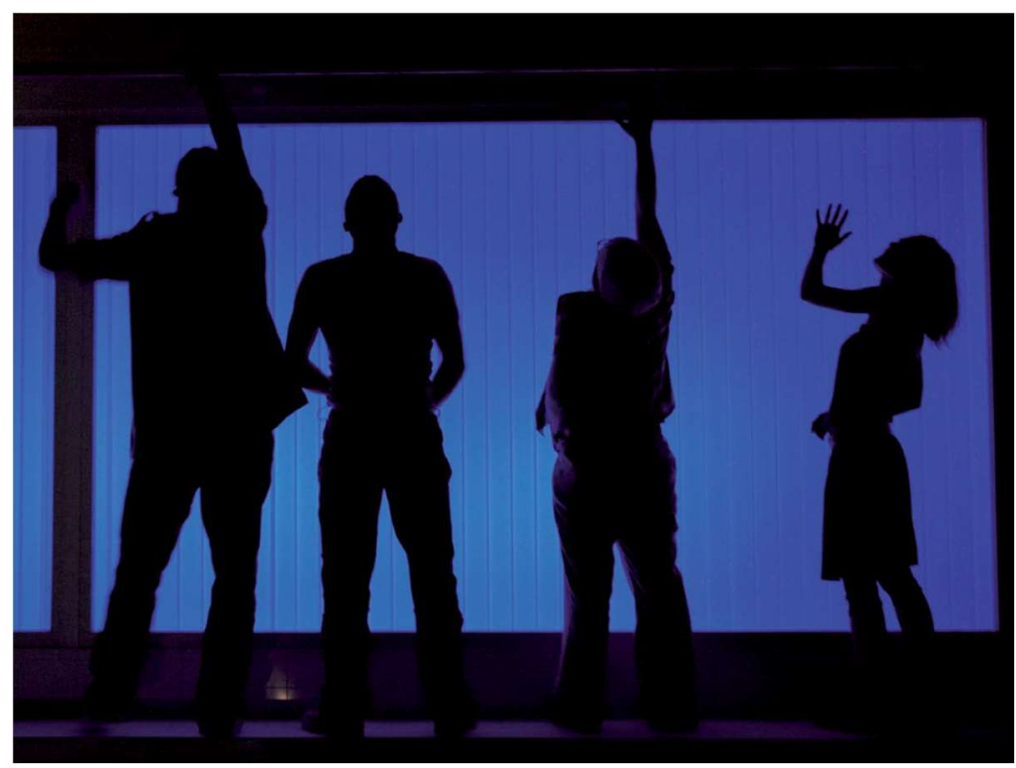

Atores em cena, na montagem de Pool (no water), em Londres. Disponível em https://www.franticassembly.co.uk/productions/pool-no-water\#resources. Acesso em 12 de dezembro, 2019.

Por sua vez, a peça Pool (no water), em seu espetáculo original, surgiu de uma parceria entre Ravenhill e o grupo de teatro britânico Frantic Assembly. Sua estreia foi na cidade de Londres, em 2006, no Teatro Royal Plymouth, na sala Drum. Criada a partir de um processo colaborativo, apresenta um ponto de vista cético sobre a (im)possibilidade de o nosso corpo comunicar significados "verdadeiros" e "fluídos" e que coadunam, por exemplo, com teorias da performatividade, desenvolvidas por Judith Butler, expondo alguns dilemas centrais encontrados no teatro contemporâneo.

Pouco estudada, a peça Pool (no water) não recebeu a devida atenção da academia e dos produtores e espectadores de teatro. E o crítico Aleks Sierz, outrora entusiasta da obra de Ravenhill, em artigo publicado em 2008, afirma ter havido "uma queda de qualidade" no teatro inglês se comparado ao do final dos anos 1990, citando de passagem a peça $\mathrm{Pool}$ como meio de fortalecer os seus argumentos ${ }^{8}$. Mais do que por uma suposta

\footnotetext{
${ }^{8}$ SIERZ, A. Reality sucks: the slump in British new writing. PAJ 89 (Volume 30, Number 2), May 2008, pp. 102-107.

Nesse artigo, Sierz sugere que jovens dramaturgos ingleses, como Mark Ravenhill, deveriam passar a se espelhar na obra de seus colegas irlandeses como na de Conor McPherson:
} 
queda de qualidade, essa peça se diferencia das demais obras, não só de Ravenhill como, também, das de outros seus contemporâneos, por causa da radicalização formal e dos temas tratados. Peças destoantes como Pool levaram críticos e estudiosos a reverem apontamentos que, muitas vezes, eram panorâmicos e, de certo modo, generalizadores sobre o trabalho desse e de outros dramaturgos daquela época.

Ambas as peças se debruçam sobre questões envolvendo sexualidade, violência e o clima político-social em que vivem os seus personagens, enquanto tematizam como as transações (econômicas) próprias do nosso cotidiano (no presente e no passado) influenciam a cultura britânica. Os esquemas nos quais os seus personagens tentam se inserir, incorporando-se ou destruindo-se neles, assim como a intersecção entre transações comerciais, violência, anomia e sexo são preocupações centrais envolvidas nesses dois textos dramatúrgicos.

Logo após $S F$, Ravenhill escreveu uma adaptação livre da peça Fausto ${ }^{9}$, intitulada Faust is dead (1997), em que o protagonista Alain, um filósofo francês, aparentemente pós-modernista, está participando de um circuito de entrevistas nos EUA a fim de divulgar seu livro mais recente, no qual trata indiretamente de temas como "a morte do homem" e "o fim da história". No primeiro volume publicado com as peças de Ravenhill

Mark Ravenhill's Product (2005) and Pool (no water) (2006) both show distinctly Crimpian and Churchillian influences. [...] Still, maybe the opposition between literalists and metaphysicals is not the right way of seeing the slump in new writing in England at the moment. Isn't it a bit stark to confront one tradition so crudely with another? Perhaps the best plays are those that mix naturalistic dialogue with a more left-field theatrical imagination. If so, perhaps the young British playwrights should look to Ireland for inspiration: Conor McPherson's The Seafarer (National, 2006) was a play that explored the crisis in masculinity with perfect social realism but, at the same time, it featured an onstage Lucifer. Now, that's pretty metaphysical. (p. 106-7)

${ }^{9}$ GOETHE, 1808. 
incluem-se ainda Handbag (1998) e Some Explicit Polaroids (1999), que, assim como SF e Faust is dead, foram largamente traduzidas e encenadas em diversas partes do mundo. ${ }^{10}$

Em 2008, um segundo volume reunindo as suas obras produzidas até então foi publicado: Mother Clap's Molly House, Product, The Cut, Citizenship e Pool (No Water). Se, grosso modo, as peças tinham no primeiro compêndio temas mais explícitos e cenas distribuídas em episódios, formatados numa estrutura mais conservadora e dramática, no segundo volume, os textos são mais "experimentais" e seus discursos menos inteligíveis. A peça Product, escrita em 2005, marca a estreia de Mark Ravenhill como ator em uma obra de sua própria autoria. É uma crítica em tom satírico sobre a indústria do cinema, centrada em um produtor/escritor de filmes, chamado James, e em sua inexorável exposição sobre o seu novo enredo a uma jovem atriz, Olivia, que espera emplacar a sua carreira e colocar-se nos trilhos da fama graças a um filme "sério" e capaz de explicitar o seu talento.

Também bastante conhecida, a peça The Cut foi encenada pela primeira vez, em 2006, na Inglaterra. Adaptada e dirigida por Daniel Lopes, O Corte [no título do espetáculo nacional] esteve em cartaz no teatro Faap, em São Paulo, no ano de 2016. Nela, um jovem adulto chamado John procura um departamento estatal no qual Paul, um servidor público, é encarregado pela administração do procedimento conhecido como "o corte", que simboliza uma espécie de lobotomia realizada em pessoas pobres.

Mais recentemente (em 2013), foi publicado um terceiro volume contendo seis peças cujos temas variam da guerra do Iraque, da queda das Torres Gêmeas e do Muro de Berlim aos efeitos causados por doenças e pragas ${ }^{11}$. E, em janeiro de 2019, estreou no

\footnotetext{
${ }^{10}$ A afirmação é do crítico inglês Dan Rebellato (2001, p. i) em introdução feita para o livro que reúne os quatro trabalhos inaugurais desse dramaturgo inglês.

${ }^{11}$ Esse volume reúne as peças Shoot/Get Treasure/Repeat, Over There, A Life in Three Acts, Ten Plagues, Ghost Story e The Experiment.
} 
Teatro Royal Court, de Londres, a peça mais recente de Ravenhill, chamada Cane, na qual um professor do ensino médio, em vias de se aposentar, vê-se confrontado por antigos alunos que cercam a sua casa e, então, passam a atirar pedras contra a sua janela ${ }^{12}$.

\subsection{O Teatro In-yer-face}

Em 2000, quando Aleks Sierz descreveu e intitulou como In-yer-face (IYF) o teatro de Mark Ravenhill, assim como o de Sarah Kane e Anthony Neilson, o que chamava a atenção desse crítico era o modo visceral como esses dramaturgos se aproximavam de suas plateias: "trata-se de um teatro que agarra o espectador pelo pescoço e o chacoalha até que ele entenda a mensagem" (SIERZ, 2000, p. 4) ${ }^{13}$. Essa nova estética foi capaz de provocar nos atores e na plateia repostas não convencionais, tocando nos nervos e incomodando profundamente, atraindo aos teatros um público mais jovem e pouco habituado às salas de espetáculo, que passaram a lotá-las. Segundo afirma o crítico (2000, p. 5), não é “difícil” reconhecer esse tipo de teatro:

A linguagem é normalmente suja, os personagens falam sobre temas inapropriados, tiram a roupa, fazem sexo, humilham uns aos outros, vivenciam emoções desagradáveis, tornam-se repentinamente violentos. No seu melhor, esse tipo de teatro é tão poderoso, tão visceral, que força os espectadores a reagirem: eles sentem vontade de fugir do teatro ou, então, convencem-se de que essa foi a melhor coisa que já viram e querem que todos os seus amigos vejam isso também.

\footnotetext{
12 Tivemos a oportunidade de assistir ao espetáculo dessa peça, em Londres, aproveitando a nossa estada na Universidade de Surrey como pesquisador visitante.

${ }^{13}$ Tradução nossa de todas as citações bibliográficas, inclusive das peças Shopping and Fucking e Pool (no water), indicadas nas referências em língua original. A tradução de Laerte Mello (1999), usada na montagem de Shopping and Fucking em São Paulo, serviu como fonte de consulta e comparação.
} 
Esse é o tipo de teatro que nos inspira a usar superlativos tanto para louvá-lo quanto para condená-lo. ${ }^{14}$

Essas peças chocavam por empregarem uma estrutura recebida pelos espectadores como incomum ou por parecerem mais rústicas e experimentais do que o teatro com o qual o público estava acostumado. Questionando normas morais e sociais, o IYF afrontava as ideias dominantes relacionadas ao que deveria ou poderia ser mostrado nos palcos; também tratava de questões voltadas à sexualidade e ao consumismo e confrontava tabus, verbalizando o proibido e criando desconforto ${ }^{15}$.

Esse teatro, ainda nos dias de hoje, parece falar diretamente com e sobre as pessoas presentes nas plateias, sejam elas inglesas, brasileiras ou norte-americanas, por exemplo. Diferentemente do tipo de teatro que nos permite sentar e contemplar o que vemos de maneira confortável, o teatro IYF bem realizado é aquele que nos conduz a uma viagem visceralmente extrema, do tipo que nos causa profundo incômodo. Diferentemente de muitas peças que apenas mencionam a violência, a especificidade de $S F$, como é própria do teatro $I Y F$, está na encenação constante de modos variados de violência: na imoralidade, na inação e no individualismo levado às últimas consequências.

\footnotetext{
${ }^{14}$ Nas linhas a seguir, o crítico Aleks Sierz (2000, p. 5) procura responder à seguinte pergunta, "como você pode dizer se uma peça é do tipo in-yer-face?":

"It really isn't difficult: the language is usually filthy, characters talk about unmentionable subjects, take their clothes off, have sex, humiliate each another, experience unpleasant emotions, become suddenly violent. At its best, this kind of theatre is so powerful, so visceral, that it forces audiences to react: either they feel like fleeing the building or they are suddenly convinced that it is the best thing they have ever seen, and want all their friends to see it too. It is the kind of theatre that inspires us to use superlatives, whether in praise or condemnation.",

${ }^{15}$ Aleks Sierz (2000, p.xi), na introdução do seu livro In-Yer-Face Theatre: British Drama Today, fala com entusiasmo sobre o teatro que ele mesmo procura descrever:

"This is a personal and polemical history of British theatre in the nineties, the most exciting decade for new writing since the heady days sparked off by John Osborne's Look Back in Anger in 1956. " [Essa é uma história pessoal e polêmica do teatro britânico dos anos 1990, a década mais entusiasmante da nova dramaturgia desde os dias inebriantes surgidos com a peça "Olhe para trás com raiva", escrita por John Osborne, em 1956.
} 
A agressividade física (com a qual se identificou toda uma geração, a ponto de o teatro $I Y F$ virar "moda" entre os jovens) se expressa nas ações (sexualmente) violentas e na escatologia, que chamam a atenção do espectador para a tentativa de renúncia, de expurgação, das imposições feitas aos personagens, que, sem o direito de escolha, só podem reagir por meio de certa recusa corporal, capaz de expressar o sentimento de contrariedade, no sentido figurado de vomitar e se autoflagelar, imposto pela situação determinista do enredo ${ }^{16}$.

\subsection{A geração dos filhos de Margaret Thatcher}

Como no caso de outros dramaturgos da geração de 1990, os anos de formação de Ravenhill transcorreram durante o governo de Margaret Thatcher. Em 1979, quando Thatcher tornou-se primeira-ministra, Ravenhill tinha 13 anos; no final de seu último mandato (sucessivamente, o terceiro), ele completava 24 anos. O Partido Conservador manteve-se ainda no poder por mais sete anos, sob a liderança de John Major. No entanto, a influência de Margaret Thatcher dominou a política britânica por cerca de duas décadas até a vitória acachapante do reformulado Partido Trabalhista em 1997. A política dos anos Thatcher afetou a cultura e o teatro não só em decorrência dos graduais cortes de subsídios e das medidas econômicas neoliberais e alinhadas às determinações do mercado, mas também pelos temas e formas que acabaram surgindo e que demonstravam uma

\footnotetext{
${ }^{16} \mathrm{Na}$ estreia da peça Blasted (1995), da dramaturga Sarah Kane, o crítico teatral britânico Ken Urban (2008, p. 38) afirma que "o mundo do teatro recebeu aquilo que menos esperava [naquele momento]: um chute no traseiro, um soco direto no olho e um murro na boca do estômago". Sem saber exatamente o que iriam encontrar, os espectadores presenciavam cenas de canibalismo, perfuração ocular e estupro por via anal. A peça era tão perturbadora que as pessoas, ainda segundo Urban, tinham a sensação de que elas mesmas iriam vomitar o que haviam acabado de comer antes do espetáculo. $\mathrm{O}$ ato de vomitar, que repetidas vezes ocorre ao longo da peça Shopping and Fucking, de Ravenhill, revela de maneira figurada uma tentativa de renúncia, ou de expurgação, contrária às determinações do meio.
} 
consciência política distinta da que houvera em outros momentos da cena teatral britânica ${ }^{17}$.

As muitas e difíceis mudanças, para pior, incentivadas pela primeira-ministra ajudaram a mudar os rumos do teatro britânico. Durante os anos 1970, tradicionalmente visto como o auge do teatro político inglês, houvera um significativo aumento no número de companhias de teatro alternativas, algo engendrado pela atividade política das décadas anteriores - uma era vista por partidários da primeira-ministra como responsável pelos males sociais e econômicos enfrentados nos anos $1980^{18}$.

No período Thatcher, as companhias de teatro foram financeira e artisticamente desencorajadas e precisavam provar ser "uma indústria de sucesso que oferecia um bom retorno ao investimento público". As vias de financiamento eram sutilmente usadas como uma forma de censura: “companhias que empregavam conteúdo político e que criticavam as políticas governamentais corriam o risco de sofrer cortes de subsídios durante o próximo ano financeiro."19

Ironicamente, os cortes orçamentários do governo e as políticas de livre mercado não impediram que se originasse um novo grupo de dramaturgos nos anos 1990, que veio

\footnotetext{
17 "Thatcherite policies affected the theatre, not just in the gradual erosion of subsidization and implementation of the market driven economy, but also in the subject matter and use of dramatic form" (D’MONTÉ, 2008, p. 79). [Políticas da era Thatcher afetaram o teatro, não apenas no que se refere aos cortes graduais de subsídios e das implementações de políticas econômicas voltadas para o mercado, mas também no que diz respeito a temas e usos da forma dramática.]

18 "By necessity, the many changes wrought to society by Thatcherism also helped to change the tenor of British theatre. During the 1970s, traditionally seen as the high point of British political drama, there had been a great increase in alternative theatre companies, engendered by political activity during the previous decade - an era, incidentally, seen by Thatcherite followers as the begetter of social ills in the 1980s" (D'MONTÉ, op. cit., p. 80). [Por necessidade, as diversas mudanças causadas à sociedade pelo governo Thatcher também ajudaram a mudar o tom do teatro britânico. Durante os anos 1970, tradicionalmente visto como como o ponto alto do teatro político britânico, houve um aumento significativo das companhias de teatro alternativas, engendradas pelas atividades políticas durante a década anterior - uma era, incidentalmente, vista pelos seguidores de Thatcher como a geradora dos males sociais dos anos 1980.]

${ }^{19}$ Under Thatcher, theatre companies were financially and artistically discouraged, and the arts were increasingly required to prove themselves as 'a successful industry that offered a good return on public investment'. Funding was subtly used as a form of censorship: companies deploying political content that criticized governmental policy ran the risk of subsidy cuts during the next financial year tackled (PEACOCK, 1999, p. 54).
} 
a público com uma série de sessões experimentais em teatros periféricos de Londres, Edimburgo e Glasgow ${ }^{20}$. Aleks Sierz chama os dramaturgos In-yer-face, nascidos nos anos 1970, de "Filhos de Thatcher" por terem crescido durante um governo conservador que durou 18 anos: governo este que fomentou o sentimento de anomia geral, alienação e agressividade presentes em peças como Shopping and Fucking e Pool (no water), ambas de Ravenhill. Apesar de o In-yer-face não ser capaz de denunciar explicitamente os males dos anos Thatcher, o fato de muitas de suas peças se concentrarem em personagens em uma faixa etária jovem traduz o sentimento de uma geração de dramaturgos que cresceu sob aquele regime ${ }^{21}$. Segundo Sierz (2000, p. 36):

A queda do Muro Berlim e a saída de Margareth Thatcher do governo mostraram às pessoas abaixo dos vinte cinco anos que, apesar das evidências da ossificação política, as mudanças eram possíveis. O fim do partidarismo ideológico da Guerra Fria libertou a imaginação dos jovens. Eles podiam assumir uma posição crítica ao capitalismo sem a necessidade de escrever peças do tipo "state-of-the-nation". Era possível ser cético em relação ao machismo sem ser dogmaticamente

\footnotetext{
20 "Ironically, the government cutbacks and free-market policies brought forward a new group of playwrights in the 1990s, showcased by a series of experimental seasons at fringe theatres in London, Edinburgh and Glasgow. Judy Upton was named one of the ten best dramatists in 1996, with others including Jez Butterworth, Nick Grosso, Sarah Kane, Martin McDonagh and Joe Penhall. These were young playwrights, says Benedict Nightingale, whose work has premiered at one of the London fringe theatres: 'Each of them has a distinctive voice, although behind the diversity there are similarities of style and content. Together they express the feeling of a generation formed by the 1980s. "' (D'MONTÉ, 2008, p. 82). [Ironicamente, os cortes do governo e políticas de livre mercado fizeram surgir um novo grupo de dramaturgos nos anos 1990, apresentando-se em temporadas experimentais realizadas em teatros alternativos, em Londres, Edimburgo e Glasgow. Judy Upton foi considerada como entre os dez melhores dramaturgos em 1996, entre outros, incluindo Jez Butterworth, Nick Grosso, Sarah Kane, Martin McDonagh e Joe Penhall. Esses eram jovens dramaturgos, afirma Benedict Nightingale, cujo trabalho estreiou em um dos teatros alternativos de Londres: "Cada um deles tinha uma voz distinta e, apesar da diversidade por trás deles, havia semelhanças de estilo e conteúdo. Juntos expressavam os sentimentos de uma geração formada nos anos 1980”.]

21 "The fall of the Berlin Wall and the exit of Margaret Thatcher showed those under twenty-five that, despite the evidence of political ossification, change was possible; the end of Cold War ideological partisanship freed young imaginations. Youth could be critical of capitalism without writing state-of-thenation plays; it could be sceptical of male power without being dogmatically feminist; it could express outrage without being politically correct"' (SIERZ, 2000, p. 36).
} 
feminista. Era possível expressar indignação sem ser politicamente correto.

Os valores fundamentais do programa político de Margaret Thatcher, "as virtudes da competição, a escolha individual, o empreendedorismo e a acumulação de capital como um dever moral" ${ }^{22}$, seriam atacados em muitas peças dos escritores In-yer-face. Os preceitos neoliberais eram praticados pelo governo Thatcher como se fossem retirados "do manual de divulgação do mercado de consumo e citado ipsis litteris para parecer doce aos ouvidos de cada consumidor", normas estas que os governos conservadores subsequentes seguiram com fidelidade - como no caso da "carta do cidadão" de John Major, que denominou os membros da comunidade nacional como "clientes satisfeitos"23.

Na tentativa sistemática de transformar a sociedade e seus valores, Margaret Thatcher é sempre lembrada por frases "brilhantes e outras nem tanto", como a de que “"Não há sociedade' [...] 'Existem apenas indivíduos e famílias"”24. Seu governo abriria o caminho para o consumismo desenfreado, e a sua linguagem até hoje influencia as administrações britânicas seguintes, inclusive as do Partido Trabalhista. O vocabulário dos políticos só reconhece os indivíduos e suas famílias como sujeitos com deveres, administrados "ao estilo indústria doméstica" 25 . Os cidadãos que não criassem as suas próprias condições de acesso ao consumismo ou não se entusiasmassem com tal prática passaram a ser julgados e vistos como problemáticos, ineficazes e prejudiciais ao sistema econômico do país.

\footnotetext{
${ }^{22}$ REBELLATO, 2001, p. xvi.

Dan Rebellato, dramaturgo e professor de artes cênicas da Universidade Royal Holloway em Londres, escreveu os comentários introdutórios e as notas da publicação de Shopping and Fucking (2001).

${ }^{23}$ BAUMAN, 2007, p. 181.

${ }^{24}$ THATCHER apud BAUMAN, 2008, p. 183.

${ }^{25}$ Op. cit., p. 184.
} 
A geração retratada nas peças de Ravenhill, que cresceu ainda numa Inglaterra sob o temor de ataques suicidas, vendo pela TV a queda do muro de Berlim e experimentando drogas sintéticas em festas de música eletrônica, encontrava no In-yerface a sua própria voz. Os jovens, atormentados pelos horrores que habitavam o imaginário ligado à guerra nos Bálcãs e ao discurso antissocial de Margaret Thatcher e John Major, "reagiram a essas mudanças culturais com raiva e insegurança"26. Tais sentimentos, demonstrados por meio de "uma dor pessoal", eram muitas vezes entendidos como uma postura apática do dramaturgo, que se concentraria, em suas peças, nas narrativas individuais de cada personagem ${ }^{27}$.

As peças eram recebidas como uma resposta ao processo de privatização da vida e do espaço públicos realizados de maneira desenfreada pelos governantes da época e em nome da globalização.

Os anos 1990 se caracterizaram por uma liberdade teatral considerada como sem precedentes. A queda do muro de Berlim e a saída de Margaret Thatcher do governo mostraram às pessoas na faixa dos vinte e cinco anos que, apesar das evidências de ossificação política, mudanças eram possíveis ${ }^{28}$. Os jovens podiam ser críticos em relação ao capitalismo sem que fosse preciso escrever peças engajadas do tipo "state of the

\footnotetext{
${ }^{26}$ Nas linhas em itálico, no original em inglês, o dramaturgo David Eldridge (1999, p. 55), contemporâneo ele de Mark Ravenhill, analisa o modo como a sua geração reagiu ao contexto histórico daquela época: Essa geração teve o otimismo juvenil esmagado pelos novos horrores que invadiam a imaginação e assumiam a forma de atrocidades, estas cometidas nos Balcãs, assim como que pelo senso de revolta causado pela erosão do sentimento de comunidade e sociedade que assolou o Reino Unido e que advinham das iniciativas mal-intencionadas de Thatcher e Major. [This generation had had its youthful optimism pickled by the new horrors that visited their imagination in the shape of atrocities in the Balkans and by a sense of outrage at the erosion of the UK's notion of community and society by the mean-spirited Thatcher and Major malaise. We responded to that shifting culture with dismay and anger.]

${ }^{27}$ Esses sentimentos, expressos nas peças por meio de narrativas individuais, baseavam-se naquilo que Aleks Sierz (2002, p.12) considerava como sendo resultado mais de "dores pessoais do que [dos efeitos] de políticas públicas" ["personal pain rather than public politics", no original em inglês].

${ }^{28}$ A queda do muro de Berlim ocorre em 9 de novembro de 1989, e Margaret Thatcher permanece no cargo de primeira ministra no período que se estende de 4 de maio de 1979 a 28 de novembro de 1990 .
} 
nation" ${ }^{29}$ e ser céticos sobre o machismo em nossa sociedade sem serem feministas dogmáticos, assim como podiam demonstrar indignação sem serem politicamente corretos.

Os cortes de subsídios realizados durante o governo Thatcher no final dos anos 1980, que levaram à queda de espectadores, além de uma crise generalizada de confiança nos profissionais envolvidos com as artes cênicas, resultou num teatro levado a cabo a partir de práticas comerciais agressivas e num ambiente economicamente hostil. Diretores artísticos como Stephen Daldry, responsável pelas primeiras produções de $S F$, foram imprescindíveis, financiando uma gama de novas produções.

Nesse período, pelo menos, trinta novos nomes surgiram no cenário londrino, liderados por jovens dramaturgos como Sarah Kane, Anthony Nielson e Mark Ravenhill, que, em pouco tempo, passaram a ser conhecidos não só pelos espectadores da Inglaterra e, em seguida, da Europa, como também dos EUA e, então, da Austrália e América Latina.

Aos olhos de Ravenhill, mesmo com a ascensão e a retomada do governo pelo Partido Trabalhista, esse momento político não passava de "um faz de conta", pois ninguém acreditava que as mudanças viriam de maneira real. $\mathrm{O}$ dramaturgo descreve o primeiro pronunciamento de Tony Blair, realizado em Londres, logo após a sua eleição, em 1987, como uma mis en scène na qual um grande número de membros do Partido, que aparentavam ter sido ensaiados, posicionavam-se bem à frente do palco saudando, entusiasmados, o futuro primeiro-ministro e sendo filmados por câmeras de TV instaladas logo atrás deles. Enquanto isso, a multidão era mantida separada por duas barreiras

\footnotetext{
${ }^{29} \mathrm{O}$ termo é título do livro State of the nation: British theatre since 1945, do crítico teatral inglês Michael Billington (2007) que procura traçar um panorama do teatro definido como "político" a partir do pós-guerra, ou do ano de 1945.
} 
formadas por policiais e grades, distanciada por esse vácuo, a mais de 200 metros desse cenário.

Desse modo, quem estava vendo aquilo à distância percebia que, nas palavras de Ravenhill, a apresentação da narrativa de "mudança" e "esperança" não passava de um evento formatado teatralmente. Em outras palavras, a História mostrava-se como um evento fabricável. Segundo ele, as pessoas presentes não tinham qualquer ilusão de que as mudanças prometidas não passariam da ordem do fictício e tomavam consciência de que o momento histórico por elas vivido estava sendo artificialmente construído. Ravenhill em entrevista cedida a Jörg Bochow (2015, p. 158) descreve o episódio:

Então, nós subimos a rua; e havia barreiras enormes, e as pessoas eram mantidas a duzentos ou trezentos metros de distância. E, então, havia um outro grupo de pessoas selecionadas, pertencentes ao Partido Trabalhista, que haviam ensaiado a cena. E as câmeras de TV estavam posicionadas logo atrás delas a fim de que, assim, pudéssemos ver um ângulo no qual parecia que as pessoas estavam recebendo [Tony] Blair em Londres. Mas as pessoas estavam, na verdade, atrás das barreiras; havia um campo deserto, havia câmeras, e, então, havia as pessoas que foram selecionadas como "o povo", e havia Blair. Era possível perceber que a mudança histórica que estava sendo narrada como "mudança" e “esperança" era um evento inteiramente construído e encenado. ${ }^{30}$

\footnotetext{
${ }^{30}$ So we ran up the road; and there were huge barriers and the people were kept at two or three hundred meters away. Then there was another small group of auditioned people; they were members of the Labour Party, rehearsed, and TV cameras were placed behind them, so that you could see a shot that looked as though the people were welcoming Blair into London. But the people were actually behind the barriers; there was a wasteland, there were TV cameras, and then there were the people who had been cast as the people, and there was Blair. You realized that a historical change that was being narrated as 'change' and as 'hope' was an entirely constructed, performed event.
} 
Em peças como Shopping and Fucking e Pool (no water), Ravenhill descreve uma sociedade inerte, em que gratificação pessoal e prazer usurpam todo tipo de idealismo político. 


\section{A estrutura formal}

Segue-se a análise pormenorizada e voltada para os elementos formais presentes nas peças de Ravenhill discutidas neste trabalho. Partimos, incialmente, de uma análise mais geral do enredo, a fim de nos aprofundarmos no estudo dos personagens e dos diálogos (e falas), estruturas estas que alicerçam a nossa tese. Após a apresentação dos personagens de cada peça, tratamos de algumas questões mais específicas ora voltadas para Shopping and Fucking, ora para Pool (no water). O mesmo ocorre em relação aos diálogos. Após uma apresentação e análise mais panorâmica, partimos para questões mais profundas presentes em ambas as peças. Em alguns momentos, analisamos as peças conjuntamente, comparando-as.

\subsection{Apresentação dos enredos}

Em linhas muito gerais, a peça Shopping and Fucking, doravante referida como $S F$, trata da vida e da subsistência de quatro adolescentes: Lulu, Mark, Robbie e Gary. Alienados, os personagens vivenciam numa grande metrópole situações que envolvem sexualidade, uso de drogas, amizade e afetos, sobre as quais paira um estado de violência e anomia permanentes. Ao longo da peça, surge um quinto personagem, mais velho, Brian, que os influencia por meio de uma relação de poder distinta, estabelecida entre ele e os demais.

No desenrolar da trama, os personagens buscam cada um a seu modo encontrar um sentido para a vida que levam, procurando algum tipo de trabalho ou subemprego, deslocando-se de um lugar para o outro, tentando de alguma forma ganhar dinheiro, consumir e, também, ser consumidos. Dividida em catorze cenas, a peça é costurada por 
narrativas individuais que, inseridas nos diálogos, revelam os desejos, as fantasias, a ingenuidade e as inseguranças de cada personagem. $S F$ termina em seu ponto de partida, com Mark, Robbie e Lulu reunidos no apartamento e tentando se alimentar com uma comida insossa feita para ser aquecida em aparelho de micro-ondas.

Já a peça Pool (no water), doravante referida como Pool, trata do corpo de uma dos personagens que é violentamente subjugado ao controle de práticas artísticas. E mostra um grupo de amigos que formam uma espécie de comunidade e que se envolvem em diversos projetos sociais e beneficentes, voltados, de algum modo, ao mundo da arte. Como fotógrafa, uma das participantes torna-se bem-sucedida financeiramente e decide reunir os "antigos amigos" em sua "paradisíaca" casa com piscina. Durante a festa, que marca o reencontro do grupo, a anfitriã, eufórica, mergulha na piscina sem água e se machuca gravemente.

No hospital, os amigos dela passam a documentar o seu lento processo de internação e tratamento, transformando-a em uma obra de arte bizarra. Ainda no hospital, a artista em recuperação planeja vender a uma galeria de arte as fotos e os vídeos produzidos durante o período em que esteve hospitalizada.

Pool termina com a informação de que, dois anos mais tarde, e apesar do constante abuso de drogas antes e durante o período desse reencontro, o grupo está "limpo" e cada um deles formou a sua própria família.

\subsubsection{A repetição do enredo em Shopping and Fucking}

De caráter mimético ou algo distorcido, a repetição contínua no interior do enredo configura-se como um dos recursos de estranhamento empregados por Ravenhill em $S F$. 
A estrutura repetitiva ou de espelhamento desvirtuado aparece representada, por exemplo, no retorno do clímax/anticlímax quando a maioria das cenas termina com uma imagem sexual ou com imagens espelhadas e distorcidas, pouco conclusivas. Uma estória de compras [shopping story], narrada, no início, por Mark - uma fantasia em que ele compra Lulu e Robbie de um "homem gordo" no supermercado - é reprisada no final quando ele descreve uma versão metamorfoseada da mesma narrativa; Mark é expulso da clínica de reabilitação porque teve um rápido contato sexual no banheiro com outro interno, o que, então, vai refletir na estória de banheiro [toilet story] envolvendo Diana e Fergie; a dificuldade de Lulu em dividir as porções de comida congelada espelha-se na cena em que Gary oferece um prato de macarrão instantâneo a Mark; Robbie é demitido de seu emprego em uma rede fast-food depois de ser atacado por um cliente que empunhava um garfo de plástico, e Lulu testemunha a agressão sofrida pela atendente de uma loja de conveniência; a regra principal de um traficante: "quem vende não deve usar" reflete-se em "nós precisamos de algo [...] um conjunto de regras", presente na fala de Brian; o argumento de Robbie: "foda-se o dinheiro" é contraposto ao de Brian: "dinheiro é civilização". O final traz um paralelo importante com o início: o retorno aonde tudo começou, os três protagonistas comendo juntos no flat, restabelecendo entre si a relação triangular.

Essas duplas de elementos que se espelham e, ao mesmo tempo, são a versão alterada um do outro, lembram a duplicação estrutural presente, por exemplo, em obras de Beckett. Em Esperando Godot, os personagens repetem os diálogos em mais de uma cena, e a própria peça se desdobra em uma segunda parte, em muitos aspectos, quase igual à primeira, com pequenas variações. Essa duplicação importa no tema, reforçando, por exemplo, a imobilidade, a dificuldade de verbalizar, de fazer sentido e a falta de perspectiva, de quem é incapaz de enxergar o futuro em suas ações. Para Theodor Adorno 
(1974, p. 10-11), “[as peças de Beckett] explodem por dentro a arte que uma proclamação de engajamento determina a partir de seu exterior e, portanto, apenas na aparência" 31 . Nesse sentido, em SF (e também em Pool), as questões relacionadas ao conteúdo da peça não se dissociam dos problemas formais, mas se iluminam reciprocamente.

\subsection{O tempo e o espaço}

Em $\boldsymbol{S F}$, as inúmeras inserções ficcionais, ou descrições narrativas, perturbam o andamento da ação, causando um certo estranhamento. Muitas vezes fantasiosas, essas diversas narrativas surgem entremeadas nos diálogos. E é comum ocorrerem momentos em que o dialogismo, enquanto tal, acaba sendo suspenso em virtude desse movimento. Se, por um lado, essas pausas implicam momentos de reflexão sobre aquele universo construído a partir dos diálogos, por outro, as interrupções dialógicas acabam significando também a criação de um espaço/tempo para além da peça, ao qual somos conduzidos. Trata-se de um "intertempo", em um espaço da narrativa, contada no passado ou em algum tempo deslocado do "aqui e agora" da peça. SF aborda as seguintes temáticas: a miséria da vida social, a carência afetiva, a pobreza espiritual/intelectual, a falta de assistência pública, a falta de perspectiva, a inacessibilidade a artigos de subsistência como alimentos/alimentos saudáveis, o pauperismo dos personagens segundo seus anseios de consumo, a dificuldade de se ter uma identidade, a falta de laços sentimentais etc. As interferências narrativas, que pausam as ações próprias dos diálogos, levam-nos para além do tempo presente da peça e do seu espaço correspondente. As estórias contadas pelos personagens reforçam a influência do nosso tempo histórico sobre

${ }^{31}$ [Beckett's plays] explode from within the art which committed proclamation subjugates from without, and hence only in appearance. Cf. ADORNO, 1974, p. 87-87. 
as suas ações ao mesmo tempo em que não têm relação direta com o desenrolar imediato do enredo.

Cria-se em $S F$ um encadeamento diferente do aristotélico ${ }^{32}$, pois as cenas não formam sequencialmente uma ação única, mas apontam para ações não relacionadas que ocorrem simultaneamente: uma cena não leva imediatamente à seguinte. A estrutura sugere a ideia de paralelismo entre cenas, por exemplo, como se Robbie e Lulu estivessem sendo atendidos na enfermaria do hospital ao mesmo tempo em que Mark e Gary faziam compras. A relação entre as cenas simultâneas, que se passam em espaços diferentes, configura-se somente na penúltima e última cena em que os diálogos entremeados com descrições narrativas procuram resolver os conflitos centrais que estavam ocorrendo paralelamente: o perdão da dívida junto a Brian e a sua saída definitiva de cena, além do aniquilamento de Gary, restabelecem a tríade inicial entre Lulu, Robbie e Mark.

Em Pool (no water), o presente é assombrado por um passado de remorso, inveja e ganância em que a reminiscência se torna, como sistema narrativo, o tempo da representação.

Uma única e longa cena atribui ao espaço comum uma condição, até certo ponto, estática, fixa: resumida no momento em que a amiga sofre um grave acidente na piscina. Pouco identificáveis, tanto o espaço quanto o tempo perdem importância em benefício dos diálogos que fragmentam a peça entre o presente da ação e o passado rememorado pelos personagens, que se projetam ao longo da peça em diferentes espaços-tempos: indo e voltando continuamente de um passado mais ou menos distante.

\footnotetext{
32 “Todos os acontecimentos se devem suceder em conexão tal que, uma vez suprimido ou deslocado um deles, também se confunda ou mude a ordem do todo. Pois não faz parte de um todo o que, quer seja quer não seja, não altera esse todo" (ARISTÓTELES, 1973, p. 450).
} 
Esses personagens só existem no presente na medida em que se envolvem completamente no passado, citam com exatidão os personagens do passado e reconstituem seus fatos. Nos termos de Jean-Pierre Ryngaert (1998, p. 111), assim como no teatro do absurdo, a escrita em Pool "infringe as regras espaço-temporais convencionadas" diminuindo a distância entre o que aconteceu no passado mais ou menos distante e o que é mostrado. O passado rememorado remete prioritariamente ao espaço da cena. E a escrita procura reduzir a distância entre os tempos presente e passado.

As referências contínuas ao tempo passado impedem uma coincidência exata com o "aqui e agora" da representação, representação esta que funciona mais como um ponto de vista fragmentado e confuso sobre algo que aconteceu e ainda exerce influência sobre a vida dos personagens. Naquilo que Ryngaert (1998, p. 122) denomina de "o presente visitado pelo passado", o diálogo se torna "flexível e escapa às obrigações do realismo". Os fragmentos do passado revividos por meio dos diálogos situam-se após o acontecimento maior experenciado pelos personagens: o encontro na piscina. Por fim, o período de tempo de que trata a peça $\mathrm{Pool}$ acaba sendo bem maior do que o de $S F$.

Em SF e Pool, o movimento cambiante de tempo/espaço, nem sempre coincidente com "o momento e o lugar" da fala dos personagens, acaba reforçando principalmente a primazia dos temas sobre o desenvolvimento do enredo. Ainda assim, em $S F$, a sensação causada por esse movimento truncado é o de circularidade do enredo, pois a cena inicial em que Lulu, Robbie e Mark estão reunidos no apartamento é quase idêntica à final. E, em Pool, o presente "assombrado" pelo passado tem efeito de paralisia quase total sobre a vida dos personagens que parecem presos àquele encontro na piscina. 


\subsection{Os personagens}

A análise a seguir parte daquilo que, segundo o crítico e professor Décio de Almeida Prado (2000, p. 88), "recomenda os manuais de playwriting" quando se trata de estudar essa estrutura: o que o personagem revela sobre si mesmo, o que faz e o que os outros dizem a seu respeito". Em seguida, aprofundamos as análises em separado observando os contornos e limitações do próprio termo "personagem" aplicado às peças em questão. Ao final, destacamos o que há de comum e diferente entre os personagens de SF e Pool. Vale dizer que a análise dos personagens não se encerra neste capítulo, estendendo-se durante quase todo o desenvolvimento deste trabalho.

\subsubsection{Apresentação dos personagens em Shopping and Fucking}

Lulu é a única representante do sexo feminino. Aparentemente, uma jovem adulta que divide o apartamento com os seus amigos Robbie e Mark. Está em busca de um trabalho e, por isso, encontra Brian, que diz ser dono de uma agência de empregos. Ao longo da entrevista, alguns traços de sua personalidade são apresentados. Ela se diz distante dos pais e fala sobre a sua disposição para trabalhar: "Nós temos que comer. Nós temos que nos virar" ${ }^{\prime 3}$. Lulu lhe revela também ter formação de atriz.

É ela quem administra a comida pré-pronta e a serve aos dois outros personagens nas três vezes em que isso ocorre. Na cena 12, Lulu expressa a sua vontade de querer mudar de vida: "Não, eu quero ser livre. Não quero viver desse jeito."34, enquanto, segundo a rubrica, toca o sino do micro-ondas alertando-os sobre a comida que já está pronta para o consumo. Robbie e Mark não aguentam mais aquela comida, e ela os

\footnotetext{
${ }^{33}$ Op. cit., p. 12.

${ }^{34}$ Op. cit., p. 58. No. I want to be free. I don't want to live like this.
} 
aconselha: "Vamos, você pode ter o mundo aqui. Todos os sabores do mundo. Você tem um império sob este celofane. Olha: China, Índia, Indonésia"35. Lulu sugere a possiblidade de por meio de um sistema de mercadorias globalizado romper as barreiras do individualismo, compartilhando aquela comida com os demais personagens e, assim, indiretamente, contradiz traços do momento ideológico e econômico característico do período Thatcher. Além disso, essa descrição da "incrível variedade dos alimentos", como se Lulu venerasse aquele tipo de comida, acaba servindo como um meio de ironizar o discurso típico da época voltado para a valorização de um mundo supostamente sem fronteiras.

Na cena 5, ela pratica um pequeno furto roubando uma barra de chocolate. E, em alguns momentos da peça, fala sobre as injustiças sociais ao redor do mundo ${ }^{36}$. É ela quem surge com a ideia de criar uma rede de telessexo para recuperar o dinheiro que ela e Robbie devem ao personagem Brian. Assim revela ter aptidão empreendedora.

Mark, um jovem adulto, é o protótipo do protagonista, disposto a uma virada em sua vida pessoal, aparenta ser ex-namorado de Robbie e é amigo de Lulu, com quem vive junto. Logo na primeira cena, quando Robbie e Lulu tentam alimentá-lo com uma comida insossa de micro-ondas, ele a rejeita, vomitando-a na tentativa de assumir uma postura de aversão ao imperativo do consumismo:

Lulu - Vai. Experimenta um pouquinho. (pausa) Vai. Você precisa comer. (pausa) Olha, por favor. Tá uma delícia. Não tá?

Lulu - Aqui todo mundo tem que comer. Vai, vamos. Só um pouquinho. Faz isso por mim, vai.

\footnotetext{
${ }^{35}$ Op. cit., p. 61. Come on, you've got the world here. You've got all the tastes in the world. You've got an empire under cellophane. Look, China. India. Indonesia.

${ }^{36}$ Op. cit., p. 28.
} 
(Mark vomita.)

Robbie - Merda! Merda! $!^{37}$

É o personagem que decide abandonar Robbie e Lulu a fim de se internar: "Eu quero me tratar"; "Eu quero ficar sozinho por um tempo"38. Os diálogos anunciam que ele é um viciado em drogas, sem sabermos exatamente quais são essas drogas. Posteriormente, tornar-se-á claro que representam, além de entorpecentes, todas as formas legitimadas de consumo.

Na cena 4, Mark contrata Gary para um programa sexual e acaba passando a noite na quitinete do michê adolescente e envolvendo-se com ele até as cenas finais da peça.

De certo modo, a luta de Mark contra o seu enquadramento no sistema acaba sendo mais destacada que a dos demais personagens, o que lhe traz, comparativamente, mais sofrimento e uma carga dramática exclusiva, por ser o único personagem que tem a chance de se transformar. Só ele percebe algo de artificial em tudo aquilo.

Na cena 6, quando Gary tenta contar um pouco sobre a sua infância, Mark não quer dar ouvidos à estória e reage agressivamente, desejando evitar qualquer “envolvimento": "PARA, CARALHO! QUER CALAR A PORRA DESSA BOCA?”39.

Mark se distancia de Robbie e Lulu e, contraditoriamente, aproxima-se de Gary. Ambos passam um tempo juntos na quitinete do michê e transam no provador de uma

\footnotetext{
${ }^{37}$ Op. cit., p. 3. Lulu - Come on. Try some.

Pause.

Come on. You must eat.

Pause.

Look, please. It's delicious. Isn't that right?

Robbie - That's right.

Lulu - We've all got to eat. Here. Come on, come on. A bit for me.

Mark vomits.

Robbie - Shit. Shit.

${ }^{38}$ Op. cit., p. 4. I want to get sorted; I want to be alone for a while.

${ }^{39}$ FUCKING SHUT UP OK? KEEP YOUR FUCKING MOUTH SHUT. (Grafia em letras maiúsculas no original.)
} 
loja enquanto fazem compras. No final, ele se junta a Lulu e Robbie e termina a peça com os outros dois no mesmo flat do início de $S F$.

Robbie, em certo sentido, parece o mais dependente e infantilizado dos personagens. No trio que forma com Mark e Lulu, ele é o mais dependente. Durante toda a peça, sujeita-se às decisões tomadas por Lulu, tentando ajudá-la na venda das drogas e no serviço de telessexo. Anteriormente a isso, Robbie seria, segundo uma de suas narrativas contadas na terceira cena, atendente de uma rede de lanchonetes fast-food, e teria sido demitido ao se envolver em uma discussão com um cliente que, então, tê-lo-ia agredido com um garfo de plástico.

Esse personagem, assim como Lulu e Mark, acabam servindo como antagonistas a Brian, por terem uma dívida com ele e que precisam sanar no final, e a Gary que, ao longo da peça, aproxima-se cada vez mais de Mark, fazendo um contraponto à espécie de triângulo amoroso que Robbie, Lulu e Mark formam desde o início de $S F$.

Ainda na mesma cena, Robbie é responsável por uma das falas mais consagradas dessa peça, quando fala sobre "as estorinhas" em oposição às "grandes estórias" da qual trataremos mais adiante. Nessa mesma cena, mais uma vez, Robbie é vítima da comida pré-pronta que Lulu repetidas vezes lhe serve e, então, tenta argumentar, "não tem sabor. Esse negócio não tem sabor de nada"40.

Na cena 13, Robbie também participa do jogo narrativo que culminaria com a suposta morte de Gary. Nessa mesma cena, Robbie, juntamente com Lulu, contabiliza o montante final e suficiente para sanar a dívida com Brian. E, na cena 14, Robbie,

\footnotetext{
${ }^{40}$ Op. cit., p. 62. There is no taste. This stuff tastes of nothing.
} 
juntamente com Mark e Lulu, terminam a peça se alimentado e, dessa vez, de maneira surpreendente, saboreando a comida pré-pronta.

O personagem Gary, inicialmente, surge como um antagonista ao trio formado por Mark, Robbie e Lulu, pois, em certa medida, esse triângulo é temporariamente desfeito quando o michê surge em cena. Descrito como um adolescente de 14 anos, e, assim como os demais, distante da família, vive sozinho numa quitinete, na qual recebe os seus clientes. É ali que Gary recebe Mark, na cena 4, para um programa sexual.

No diálogo inaugural entre ambos, Gary fala das mudanças capazes de modificar o modo como os encontros com seus clientes ocorrerão em virtude dos avanços tecnológicos: "É claro que um dia vai ser virtual. É o que dizem por aî" ${ }^{41}$. E a preocupação dele é de se adaptar às mudanças: "Eu venho me preparando pra isso. Pensando num jeito de investir nisso. Uma cadeia, uma rede, ou sei lá o quê. Você já trepou desse jeito?”42.

Na cena 6 , segundo conta a Mark, Gary afirma ter sofrido constantes abusos nas mãos do padrasto. Na cena 8 , ele volta a falar com Gary sobre a violência e os abusos praticados pelo padrasto e sobre a sua vã tentativa de buscar ajuda do aparato público.

Na cena 13, Gary irá se tornar o protagonista de uma estória fantasiosa que, porém, resultará na provável morte real do personagem, que oferece um pagamento a Mark, Robbie e Lulu para levar a cabo o seu desejo de morrer: Mark - Por que estamos jogando isto?/Robbie - Porque ele quer./Mark - É um jogo estúpido. ${ }^{43}$

\footnotetext{
${ }^{41}$ Op. cit., p. 22. Mark - Course, any day now it'll be virtual. That's what they reckon.

${ }^{42}$ Op. cit., p. 22. I'm planning on that. Looking to invest. The net and the Web and that. You ever done that?

${ }^{43}$ Mark - Why are we playing this?/Robbie - Because he wants to. Mark - It's a stupid game (RAVENHILL, 2001, p. 67).
} 
Entre os personagens, Brian, além de mais velho, tem um filho. Difícil afirmar se é, de fato, um antagonista ou uma referência para os demais. Ele surge, inicialmente, na entrevista de emprego de Lulu fazendo anotações em sua caderneta, pedindo que ela fale sobre suas qualidades, interprete um personagem e, inesperadamente, tire as roupas como parte da interpretação. Ao final, o emprego/desafio que ele tem para oferecer a ela é o de vender drogas.

Brian detém um discurso impositivo, afirmando, por exemplo, haver por trás da "dedicação" do fillho, da "beleza", de "Deus", do "Paraíso", por trás de toda ação, sobretudo, as que nos envolvem, o "dinheiro". Ele está em melhor condição financeira que os outros, mas ainda submetido às leis impostas pela classe verdadeiramente dominante, só representada na peça por meio alegórico, como pelo "homem gordo", que, na primeira cena, teria colocado Robbie e Lulu à venda, segundo "a estória sobre compras" [shopping story ${ }^{44}$ contada pelo personagem Mark.

Além dos conflitos paralelos existentes entre Lulu, Robbie, Gary, Mark e Brian, analisados ao longo desta tese, estabelece-se, em maior grau, uma oposição de classes que engendra uma contradição, aos moldes do que ocorre no teatro épico de Bertolt Brecht, envolvendo de um lado os personagens, representados por tipos comuns: embrutecidos pelo sistema e do outro, uma elite privilegiada e quase inexistente na peça. Segundo a dramaturga e ensaísta Renata Pallottini (2013, p. 145), à noção de conflito, as peças de Brecht opõem essa categoria, a da contradição:

O conflito, sob esse ponto de vista, seria uma contraposição de sentimentos, de vontades, objetivos dos personagens. Cada polo de um conflito nasce de um personagem ou grupo de personagens

\footnotetext{
${ }^{44}$ Esse trecho é analisado em detalhes mais adiante neste trabalho.
} 
- pelo menos na maior parte das vezes. A contradição é maior do que isso; ela está acima dos personagens, que são o tempo todo submetidas a ela. No conflito pode-se opor polos quaisquer: duas famílias inimigas, dois homens que amam a mesma mulher, dois indivíduos que pretendem o mesmo poder. Na contradição, os dois polos estão como que ligados, um supõe o outro, um não pode existir sem o outro; não podem existir escravos sem senhores, patrões em empregados, pobres sem ricos, e vice-versa.

A sobrevivência dos personagens representada em condições degradantes de consumismo depende de um sistema econômico pautado por uma elite que só existe simbolicamente na peça.

\subsubsection{O limite dos "personagens" em Shopping and Fucking}

Peter Szondi, em Teoria do drama moderno (2011), a fim de fundamentar as suas análises acerca daquilo que postula como a "crise do drama", estabelece um paradigma da forma dramática convencional - vigente até o fim do século XIX -, a que ele denomina de "drama absoluto". Segundo o teórico, o drama absoluto é aquele que se pauta em três categorias dramáticas convencionais: a relação inter-humana, o diálogo e o tempo presente. Segundo Elen de Medeiros (2018, p. 1):

Essa formulação, em vista do pressuposto da pièce-bien-faite e ansiando estabelecer o máximo possível a verossimilhança da cena ao modelo burguês projetado ao público, estabelecia uma normativa quanto à forma de representação, circunscrevendo a cena fechada em si mesma, na medida em que a caixa cênica é o limite do drama. Ou seja, 
a relação entre as vontades individuais das personagens projetadas a partir da construção dialógica e que assume sempre o tempo presente cria no espaço cênico fechado a ilusão dramática, convencendo o seu público de que o que acontece em cena termina nela.

Em $S F$, o tema onipresente do ferimento, da dor, define a reconfiguração dos personagens. Em relação ao personagem do "drama absoluto", $\mathrm{S} F$ constitui, aos trancos, o que poderia ser definido como uma "subversão limitada", por meio de uma "prática paródica" que resulta numa ressignificação do termo "personagem".

SF emprega personagens, até certo ponto, convencionais como meios de representação. A peça apresenta cinco personagens que são claramente circunscritos por uma teia de afinidade e desejo: Lulu, Robbie e Mark vivem juntos e estão envolvidos entre si emocional e sexualmente; Gary envolve-se aos poucos com Mark e, então, indiretamente com Lulu e Robbie; e Brian, a partir da aproximação "profissional” com Lulu, também, aproxima-se dos demais como um antagonista: por ser mais velho e por deter algum capital.

Num "drama absoluto" (SZONDI, 2001, p. 8), o diálogo é a força capaz de propagar e renovar o status quo ficcional. Essa interação produz certa polaridade e estabelece relacionamentos entre os personagens investindo-lhes de certos atributos e papeis, como o sadismo de Gary, a ingenuidade de Robbie, o amor incondicional de Lulu, a rebeldia de Mark e o espírito "paternal" de Brian. Porém, esses personagens convencionais parodiam a figuração de certos atributos esperados como unidade, livre arbítrio e autoconsciência por noções como dependência, reclusão, isolamento e anonimato. No entanto, mesmo quando negam o desejo de se aproximarem e se envolverem entre si, como transparece a fala inicial de Mark, logo na primeira cena, sobre 
não querer qualquer tipo envolvimento pessoal, exterioriza-se nos personagens uma necessidade de codependência.

Essa "codependência" permite aos personagens uma identificação que, segundo a terminologia de Butler (2004, p. 8), torna a vida "suportável" [livable, no termo em inglês], apesar das posições oprimidas/abjetas que se lhes impõem pelo discurso do consumismo realizado em tempo integral, talvez como personagens beckettianos, unidos pela solidão e falta de sentido.

Segundo Jean-Pierre Sarrazac (2017), eles pertencem a uma categoria de coralidade negativa constituída por aquilo que esse autor denomina de "impersonagens". Trata-se, portanto, de uma "coralidade" que estigmatiza o homem; submetendo-o a uma miséria sem limites; cerceando a sua singularidade: "a personagem coral não vive apenas a experiência da separação/ela se apresenta também no humano do não-humano - no bestial ou no inanimado"45.

Gary recebe a punição por sua culpa alegada de querer ser amparado por alguém, uma figura paterna e sádica, quando, ao final da peça, é penetrado por um objeto cortante usado por Robbie, Lulu e Mark, algo que, supostamente, levaria o garoto à morte. O encadeamento dessa cena dá-se com a descrição narrativa de um ser mutante, presente na última "estorinha" da peça, contada por Mark, que a constrói a partir de um amálgama de sexualidade e gênero.

Reforçando uma espécie de círculo vicioso, o corpo do mutante emerge como os efeitos e os meios das forças produtoras do discurso. Assim, conforme Mark afirma que libertará o mutante, ele justifica o discurso e a prática (auto-)punitivos impostos a Gary por seu desejo de "querer ser cuidado" por alguém.

\footnotetext{
${ }^{45}$ SARRAZAC, 2017, p. 166
} 
Essa espécie de estupro coletivo e letal sofrido por Gary representa os efeitos e as condições advindas da opressão sofridas pelo sistema e do sentimento de "culpa" por trás da sensação de serem "perdedores" que carregam consigo os personagens. $S F$ enfatiza o corpo como o objeto e o efeito da opressão sistêmica e destrói a individualidade e a autonomia dos personagens, posicionando-os como corpos semivivos, moribundos. Desse modo, o trabalho de Ravenhill destaca a formação de personagens corporificados mas, ainda assim, anestesiados, inertes, incapazes de expressar qualquer sentimento como os de dor ou amor, por exemplo.

No geral, conquanto Lulu, Robbie, Mark, Gary e Brian, apresentem leves contornos de individualização, essa categoria é empregada a fim de desestabilizar e desfigurar a representação de personagens como sendo individualizados e verdadeiros agentes das próprias ações.

\subsubsection{A influência da figura paterna sobre os personagens de Shopping and Fucking}

A imagem paterna desvirtuada é outro elemento que causa forte estranheza e impacto em $S F$. Em vários momentos durante o decorrer do enredo, o amor e o apoio paternos são enfatizados, mesmo que as imagens variem. $\mathrm{O}$ tratamento dado à paternidade é ambíguo, recebendo tanto conotações positivas quanto negativas. Todos os personagens são influenciados pela imagem paterna. Mark funciona como esse tipo de figura para Lulu e Robbie. Eles repetidamente lhe pedem que conte a estória em que Mark fantasia ter comprado Lulu e Robbie em um supermercado: Lulu - Conta a estória das compras. [...]/ Robbie - Isso, vai. Você ainda se lembra da estória das compras (p. 4) ${ }^{46}$.

\footnotetext{
${ }^{46}$ Lulu - Tell us the shopping story. [...]/Robbie - Yeah. Come on. You still remember the shopping story.
} 
A estória das compras não mostra uma figura paterna tradicional, mas sim a ambiguidade entre o pai cuidador ("E é como se eu estivesse há tempos guardando um quarto para vocês. E eu entro com vocês no quarto. Tem comida lá. Está quente.” $)^{47}$ e predador ("Então, eu fecho o negócio. Tipo uma transferência de bens. E levo vocês. E eu não preciso explicar nada porque vocês viram a transação.”). ${ }^{48}$

Lulu costuma lembrar Mark de sua promessa: "E você disse: eu amo vocês. Eu

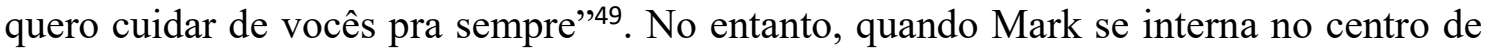
reabilitação ou, então, quando ele, posteriormente, apaixona-se por Gary, Lulu e Robbie precisam se virar sem ele. E mostram dificuldades ao se verem sozinhos, por exemplo, quando não conseguem vender as drogas. Aparentemente, estão perdidos sem uma figura paterna.

Gary, por sua vez, foi vítima de abusos constantes cometidos pelo padrasto e agora está desesperadamente procurando pela figura de um pai protetor: "Eu quero um pai. Quero alguém pra cuidar de mim. O tempo todo cuidando de mim."50. Embora ele tenha fugido do padrasto e de casa, o parceiro imaginário ideal "parece ter a mesma combinação sexual de proteção e violência" (REBELLATO, 2001, p. xxx):

Não estou procurando o amor. Eu quero ser propriedade de alguém. Quero alguém pra cuidar de mim. E quero que ele me foda. Realmente me foda. [...]. Vai machucar também, eu sei. Mas vai machucar de um jeito bom. (p. 56$)^{51}$

\footnotetext{
${ }^{47}$ And I've been keeping a room for you and I take you into this room. And thre's food. And it's warm. (p. 5)

${ }^{48}$ So, I do the deal. I hand it over. And I fetch you.I don't have to say anything because you know. You've seen the transaction. (Op. cit., p. 5)

${ }^{49}$ Lulu - And you Said: I love you both and I want look after you forever. (Op. cit., p. 4)

${ }^{50}$ Gary - I want a dad. I want to be watched. All the time, someone watching me. Do you understand? (p. 33)

${ }^{51}$ I'm not after Love. I want to be owned. I want someone to look after me. And I want him to fuck me. Really fuck me. Not like that, not like him. And, yeah, it'll hurt. But a good hurt.
} 
A decisão de tornar-se "propriedade" revela uma relação com a violência e a passividade inerentes a quem deseja ter um "lugar" no sistema, e a figura paterna imaginada pelo personagem, envolvida nesse jogo entre violência e passividade, causa na cena o efeito de estranhamento resultante do desejo de Gary de ser mercadoria em vez de sujeito.

Gary jamais fala sobre o pai de origem biológica. O seu desejo advém de um pai ausente. Em vez de ser amado, a fantasia de Gary é a de ser violentado sexualmente, com uma faca, por uma figura paterna. E Mark, Robbie e Lulu concordam em satisfazer o seu desejo, a sua maior vontade: ser "fodido" sadicamente até a morte pelo pai.

Brian, por sua vez, é o único pai biológico da peça, e faz o contraponto "normal" à figura doentia desejada por Gary. Ele está muito orgulhoso do filho e até se emociona quando mostra a Robbie e Lulu o vídeo no qual o filho aparece tocando violoncelo:

[...] e o professor diz: 'É um presente de Deus!' [...]. Uma criança que nem essa, uma criança maravilhosa - meu filho - e o instrumento não tem nada de especial, é só pegar um pedaço de madeira, umas cordas e - então -, um homem maduro, deste tamanho... chora. (p. 47) ch $^{52}$

Na expressão "meu filho", o laço filial e emocional torna-se evidente. Durante a peça, Brian frequentemente reconta a estória do Rei Leão, uma estória que ele aprendera com o pai:

Muito bem. Então, o pai está morto. Assassinado. Pelo tio. E o pequeno cresce. E você precisa ver - ele se parece com o pai. Exatamente, a cara dele. E um dia, um tipo de macaco aparece pra ele. E esse macaco diz: "É chegada a hora de você falar com o seu falecido pai". E ele corre

\footnotetext{
${ }^{52}$ his teacher says 'It's a present 'it's a gift from God'. [...]. Kid like that, nice kid-his father's son-but
} nothing special, picks up a bit of wood and string and-well-grown men cry. 
atrás desse macaco até chegar em um riacho e ele vê [...] seu próprio reflexo [...]. Então... olhando o seu próprio reflexo na água, pequenas ondas se formam, embaralham sua visão. E, aí, ele vê um fantasma. Um fantasma ou uma espécie de imagem olhando pra ele. [...] ele vê... o pai. O meu caçula quando vê essa parte... Ele fica com lágrimas enormes nos olhos. Ele sente tanto quanto eu. Porque agora a imagem do pai diz: "É chegada a hora. Já é tempo de você ocupar o seu lugar no Ciclo da Existência (palavras de efeito). Você é meu filho, o verdadeiro Rei”. E, aí, sim, ele sabe o que tem que fazer. Ele sabe quem ele tem que matar. E é isso. Essa é a nossa cena favorita. (p.9) ${ }^{53}$

O fato de Brian recontar frequentemente a estória expõe o laço de compromisso familiar ideal existente entre pai e filho, o vínculo afetivo e a ideia de continuação de um ciclo, o que fortalece uma imagem bastante idealizada da figura paterna. Brian aprendeu os ditames com o seu pai. Assim, como em Rei Leão, o filho sucede o pai em seu reinado. Essa cena simboliza a passagem da ideologia capitalista do pai de Brian para ele e dele para o filho. Assim como Mark, Brian faz as vezes de uma figura paterna para Robbie e Lulu. Ele lhes ensina os valores e técnicas necessários para poderem sobreviver na sociedade contemporânea. Aplicando certo tom didático, ele os faz vivenciar a importância do dinheiro. Quando entendem a mensagem capitalista de Brian, ele generosamente devolve-lhes o vil metal, assim como um pai recompensa os filhos com doces ou pequenas gratificações.

\footnotetext{
${ }^{53}$ Good. So now the father is dead. Murdered. It was the uncle. And the son has grown up. And you know - he looks like the dad. Just like him. And this sort of monkey thing comes to him. And this monkey says: 'It's time to speak to your dead dad.' So he goes to the stream and he looks in and he sees -[...] his own reflection.[...]. But then ... The water ripples, it hazes. Until he sees a ghost. A ghost or a memory looking up at him. His ......] Until ... he sees ... his ... dad. My little one. Gets to that bit and I look round and he's got these big tears in his eyes. He feels it like I do. Because now the dad speaks. And he says: 'The time has come: It is time for you to take your place in the Cycle of Being (words to that effect). You are my son and the one true King.' And he knows who it is he has to kill. And that's the moment. That's our favourite bit.
} 
Em $S F$, a ambivalência da figura paterna é criada a partir da justaposição entre, de um lado, a figura paterna amorosa e prestativa e, do outro, a sexual e perversa. As características sociais tradicionais, do pai protetor e disciplinador, foram transformadas em uma ambiguidade de caráter profundamente político. Em $S F$, o pai ausente é justamente o da figura protetora, um pai forte, típico de uma possível idealização na Inglaterra dos anos 1960: paternalista, do Estado de bem-estar social na Inglaterra ${ }^{54}$. Já o pai presente é o disciplinador abusivo e apegado a bens materiais. Esse novo pai, nascido na era Thatcher, altamente competitivo e que passará o legado de que "é preciso matar" (na "lei da selva" que rege a sociedade), aproxima-se da imagem do consumo e do dinheiro, algo bastante visível e bem representado no personagem Brian. Seu pai lhe disse que as primeiras palavras da Bíblia foram: "Receba. O dinheiro. Primeiro" (p. 87) ${ }^{55}$. Além disso, Brian chega a defender que o dinheiro é mais importante que o próprio pai, já que por trás de tudo, "da natureza", está "o dinheiro". Robbie, por sua vez, acredita que a figura paterna é a essência de tudo. Rebellato (2001, p. xxxi) teme que esse novo tipo paterno possa ser muito destrutivo: “Talvez, esse pai que matará a todos nós seja a força sem controle do capital, a força irrestrita do consumismo".

\subsubsection{Apresentação dos "personagens-letra" em Pool (no water)}

Sem falas com atribuições definidas, a dramaturgia original dessa peça conta com quatro atores que se revezam na função de interpretar o texto escrito pelo dramaturgo. Segundo a rubrica, esses personagens são: A, B, C e D que, aos poucos, rememoram um

\footnotetext{
${ }^{54}$ Entretanto, segundo Mandel, no final de década de 1960 e início da de 1970, a crise começa a aparecer. Os tempos áureos do capital com o Estado de bem-estar social chegam ao fim, e retornam, com isso, todas as contradições e os problemas inerentes ao próprio sistema produtor de mercadorias (MANDEL, 1990, p. 27).

${ }^{55}$ Get. The money. First.
} 
encadeamento de eventos que, de certo modo, caracteriza o grupo em oposição à personalidade da amiga famosa.

Sem a possibilidade de defini-los individualmente, podemos apenas afirmar que todos compartilham certos traços em comum. Ou seja, como vimos no enredo, por exemplo, nenhum deles veio a se tornar bem-sucedido e guardam todos certa mágoa da amiga. Incialmente, os quatro personagens formavam, juntamente com a fotógrafa bemsucedida, um "grupo", que também contava com dois outros amigos que vieram a falecer: Ray e Sally, estes, os únicos citados nominalmente ao longo da peça.

Por um lado, o grupo condena a atitude da amiga que se tornou famosa ao expor a uma situação de fragilidade pessoas afetivamente próximas e que se encontravam à beira da morte, fotografando-as: "'foi você que matou a Sally.", " "porque nenhum de nós tinha a intenção de ser reconhecido", "nós éramos um grupo", "e você tirou o nosso equilíbrio". "O grupo" afirma de maneira contraditória que "fazer arte" para eles nunca se tornaria um meio de ganhar dinheiro ou de "ser reconhecido" pelo mercado, como sugerem, ainda mais se isso envolvesse a exposição de amigos doentes.

Por outro lado, o grupo revela sentir um misto de inveja, admiração e raiva pelo fato de ela possuir uma bela casa com piscina: "ela é boa. Ela é legal. Ela tem integridade. E ela tem uma piscina agora". E, segundo uma autoavaliação dos personagens, mais abaixo no texto:

Isso não é estranho? Todo esse tempo em que ela estava entre nós como uma amiga, todo esse tempo e, ainda assim, francamente, nós projetamos o mais terrível..., suponho eu, ódio.

Ódio mortal 
Seriam as únicas palavras. ${ }^{56}$

Quando mais jovens, todos usavam drogas e festejavam juntos, além de organizarem pequenas exposições coletivas para as suas obras. Mas conforme o enredo faz referência a um tempo mais próximo do presente, percebemos o antagonismo progressivo formado pelo grupo composto pelas vozes A, B, C e D e a espécie de "Nan Goldin"57 retratada por esses personagens.

De certo modo, o grupo passou a compor um tipo comum: pessoas adultas sem emprego fixo, vivendo em casas suburbanas com as suas famílias e demonstrando certo tédio causado pela rotina de uma classe média cada vez mais sem perspectiva. Por sua vez, a amiga famosa e distante também compõe um outro tipo imaginariamente comum: rica, ela tem acesso a bens de consumo sofisticados, como a viagens, não se volta para a família e dedica-se integralmente à profissão de artista, de celebridade.

A fala não é enunciada por personagens construídos com "identidades observáveis", nos termos de Ryngaert (1998, p. 136). Embora falem, não podemos afirmar categoricamente de quem essas falas vêm, por falta de referências psicológicas, sociais ou simplesmente de identidades afixadas. Uma vez mais, e de modo mais radical, os personagens se fundem num bloco, num coro indefinido, que os condena de maneira muito mais severa a uma falta de singularidade na comparação com os de $S F$.

\footnotetext{
${ }^{56}$ Op. cit., p. 298.

'It was you who killed Sally.'

Because none of us meant to be wealthy, none of us was meant to be recognized. We are the Group. And you took away the balance.

Isn't that strange? All the time she was amongst us as a friend, and yet really we harboured the most awful...well I suppose hatred.

Murderous hatred

Would be the only word.

${ }^{57}$ Nancy "Nan" Goldin é uma fotógrafa norte-americana. Seu trabalho costuma explorar corpos LGBTs, momentos íntimos, crises decorrentes do vírus do HIV e a epidemia ocasionada por opioides. Sua obra mais conhecida é "A balada da dependência sexual" [The Ballad of sexual dependency, no título original em inglês], que documenta os próprios amigos e familiares da artista como pertencentes a um submundo.
} 


\subsubsection{O limite dos "personagens-letra" em Pool (no water)}

Essa peça, como observamos, apresenta personagens não-individualizados. Enquanto resistem à subordinação a pressupostos que emolduram à ideia de individualidade, os quatro personagens indiferenciados e sem falas diretamente atribuídas de Pool configuram, no entanto, poderosas formas de representação. As linhas faladas pelos personagens A, B, C e D, talvez um personagem amorfo e coletivo, por assim dizer, evocam emoções reconhecidas, atividades cotidianas, funções corporais e fragmentos de uma memória cultural socialmente compartilhada. O sentimento de culpa: "nós nos sentimos um pouco culpados quando pensamos sobre o sofrimento deixado para trás na cidade" mistura-se a outros de raiva, inveja e vingança: "eu sinto muito você ter precisado sofrer. Eu sinto muito que haja essa dor - mas há justiça nisso" ${ }^{\text {"58. }}$.

Ao mesmo tempo, o texto captura e expressa vivências, pensamentos e sentimentos relacionados a uma existência fragmentada. Na mesma linha, o desenrolar ficcional frágil de Pool oferece pequenos flashes de um personagem, em larga medida, anônimo e agonizante, decomposto em fotos tiradas num leito de hospital. O fato de o roteiro ser formatado a partir de fragmentos oscilantes e desnorteados é bem-sucedido ao retratar a personagem ausente, o que nos leva aos apontamentos de Sarrazac sobre o fim da figura do "personagem" e o surgimento do "impersonagem"59 cujo resultado, em larga medida, seria o de aproximar o dramaturgo dos espectadores.

\footnotetext{
${ }^{58}$ Op. cit., p. 303. "We feel a little guilty when we think of all the suffering back in the city", quando um dos personagens fala sobre questões envolvidas no abandono momentâneo dos trabalhos de caridade realizados por eles enquanto curtem a casa com piscina da amiga.

Op. cit., p. 299. "I'm sorry you had to suffer. I'm sorry there's this pain-but there is justice in this."

${ }^{59}$ SARRAZAC, 2017, p.147.
} 
Os procedimentos de Ravenhill procuram quebrar "o próprio núcleo do(s) personagem(s) ${ }^{\prime 60}$, criando neles algo de espectral, de fantasmagórico, de morto-vivo, rompendo a singularidade de personagens individualizados e criando uma espécie de representante de uma massa constituída por um tipo comum e denominada apenas por meio de iniciais alfabéticas: A, B, C e D.

Há três dispositivos principais por meio dos quais o roteiro de Pool fortalece a constituição do "impersonagem": primeiro, a negação de falantes identificáveis presentes na peça; segundo, a instabilidade gerada pelo "falso" diálogo e a fala ininterrupta; e, finalmente, a transgressão da normatividade dos gêneros masculino e feminino a favor da indeterminação e de uma certa fluidez.

O primeiro mecanismo de negação é a resistência do texto em oferecer identidades a priori para os falantes, deixando de nomeá-los. Em Pool, a dramatis persona do texto consiste em quatro "falantes" aleatoriamente nomeados A, B, C e D. Segundo Ravenhill (2006), em entrevista:

A peça escrita por mim é majoritariamente uma estória contada pelos quatro atores aos espectadores, e os atores estão começando a sentir falta do jogo interno que o diálogo lhes dá. Quando chegamos no intervalo, eu tento lhes assegurar que há um diálogo acontecendo na escrita - só que ele é com a plateia.

Enquanto nomes singularizam e podem criar uma expectativa em relação a particularidades individuais, os sinais alfabéticos que nomeiam os falantes não possuem marcadores de gênero, etnicidade ou conotações de qualquer tipo. Em larga medida, o

\footnotetext{
${ }^{60}$ Ibidem, p. 154.
} 
texto atribui as falas e mascara os falantes até o limite do seu discurso voltado aparentemente para uma classe média que vem perdendo os seus direitos na Inglaterra.

Pode-se especular que as letras alfabéticas se referem a iniciais ou pistas de identidades silenciadas ou como traços incompletos de presenças individuais que, caso contrário, seriam mostradas em sua completude.

Apesar da sugestão da presença de quatro falantes na montagem do texto original, o roteiro é composto por uma escrita com liberdade de fluidez dividido em inúmeros fragmentos. Não há qualquer sinal, como hifens, mostrando divisão de fala, e nenhuma informação é oferecida capaz de identificar os interlocutores nesses diálogos aparentes. Desse modo, o roteiro cria personagens indefinidos e incontáveis, ou seja, como um veículo estético sem marcação, a fim de retransmitir experiências humanas associadas, sobretudo, à dor mas, também, à ganância e à ascensão social e econômica a todo custo.

A segunda fonte de rejeição dos modos de caracterização dos personagens reside na subversão das falas como, por um lado, ferramenta de expressão, por meio da qual os falantes podem perceber e transmitir um senso de individualidade, e, por outro, como uma base de trocas pelas quais se comunicam e respondem uns aos outros.

Ao fazer isso, o roteiro evita estabelecer uma correlação entre o uso do diálogo no drama, com a configuração de personagens individualizados que poderiam ser identificados como inerente ao "teatro moderno" 61 . Assim, a estrutura de Pool estimula uma conversa a quatro mãos na qual os falantes se revezam em suas falas e tecem uma teia de temas compartilhados entre si:

\footnotetext{
${ }^{61}$ A nosso ver, a peça Pool anula as relações intersubjetivas e subverte o diálogo, como meio linguístico privilegiado, em vez de problematizá-los, como ocorre, segundo análise de Peter Szondi, em obras teatrais na virada dos séculos XVIII e XIX, discutidas em Teoria do drama moderno (2001).
} 
Levou algum tempo para fotografar. Uma imagem um registro um enquadramento. Mais tarde nós sentamos na sala de fumantes e dissemos a nós mesmos:

Fazer isso não foi uma coisa boa. Fazer isso foi uma coisa terrível. Por que não selecionar apagar e limpar o que você...? Por que não?

E nós fizemos. Não - vou ser honesto com você - nós quase fizemos. Mas nós nunca fizemos. ${ }^{62}$

A falta de rubricas, como se pode observar, impede a identificação dos destinatários por meio de gestos, expressões faciais, postura corporal, posicionamento no palco ou proximidade com outro personagem.

As intervenções se complementam, sugerindo que a fronteira entre os personagens necessariamente ultrapassa aquela formada entre A, B, C e D, respectivamente. Por meio do emprego simbiótico, intertextual e coral das falas ${ }^{63}$, Pool implicitamente sugere que os personagens são irremediavelmente opacos e difíceis de se dissociarem. A possibilidade de um personagem individualizado é recusada não apenas pela ausência de uma dramatis persona mas, também, pela negação ou anulação do diálogo.

Os quatro personagens indeterminados e diluídos em falas não atribuídas do roteiro continuam a resistir, pois, mesmo nas falas em primeira pessoa tanto do singular quanto do plural, a algo que impede a individualização. Um dos motivos para essa constatação é o fato de que verbalizar emoções e sentimentos não basta, por si só, para

\footnotetext{
${ }^{62}$ RAVENHILL, op. cit., p. 307.

It took a few moments to snap. An image a record a frame.

Later we sat in the smoking room and said to ourselves:

That wasn't a good thing to do. That was a horrible thing to do. Why no select delete and wipe away what you've...? Why not?

And we did. No - honest with you - we nearly did. But we never did.

${ }^{63}$ Em diversas montagens, inclusive na original (no Teatro Drum Thetre Plymouth, 2006, em Londres) diversas falas são reproduzidas em uníssono.
} 
constituir um personagem único, individualizado. Grosso modo, emoções e sentimentos são expressões de algo mais geral, no sentido de que qualquer pessoa pode senti-los independentemente de quem seja: "nós a adoramos"64, ou "mas eu senti você sentiu, escuta eu senti, que isso é errado eu sei que isso é errado mas eu senti, talvez seja apenas - alguém mais sentiu - isso é apenas um sentimento, mas um sentimento é um sentimento e eu acho que isso deveria ser honrado"65 e "Eu sou um(a) romântico(a)"66.

Depois disso, num terceiro exemplo, o texto evitando caracterizar os personagens, subverte as expectativas. Essa transgressão permite aos personagens funcionarem como um ponto de acesso fluido e cambiante. Pool não trabalha com marcadores raciais ou étnicos, mas o texto está repleto de falsos indícios quanto a determinações de sexo e gênero que falham como mecanismo de reconhecimento e verificação da morfologia dos personagens: não estabilizada e nem reconhecível.

Como resultado, os personagens de Pool evocam uma corporificação indefinida quanto ao gênero, sem jamais assegurá-lo, correspondente, portanto, ao depoimento autorreflexivo e auto-ocultante de um dos personagens da peça:

[...] você será um dos nossos como era uma década atrás todos despidos e nós somente um bando de bucetas de pintos e peitos e bundas nosso bonito banho oh pense nisso minha querida pense ${ }^{67}$.

Se, de acordo com Butler (1993), o corpo é o efeito de gêneros que só podem ser aceitos dentro dos limites das normas culturais, das leis e dos tabus existentes, a resistência do texto dessa peça em oferecer ao seus leitores informações necessárias a fim

\footnotetext{
${ }^{64}$ Op. cit., p. 295. We adore her

${ }^{65}$ Op. cit., p. 297. But I felt did you feel, listen I felt, this is wrong I know this is wrong but I felt, maybe it's only - did anyone else feel - and it is only a feeling, but a feeling is a feeling and I think that should be honoured, you know?

${ }^{66}$ Op. cit., p. 323. I'm a romantic.

${ }^{67}$ Op. cit., p. 310. You will be one of us just as it was all the decade past everything stripped away and us just a bunch of cunts of dicks and titties and bumcracks us the bathing beautiful oh think of that my darling think of.
} 
de se figurar fisicamente o corpo funciona como uma recusa dos termos sociais "segundo os quais nós nos reconhecemos" $"$.

Ao reduzir as possibilidades de fixar vozes que possam ser identificadas segundo o gênero, a raça, a morfologia, o sexo ou a etnia, a peça põe em prática, por meio da omissão, o seu desinteresse pelas normas culturais hegemônicas capazes de discernir quais as posições de gênero e as corporeidades físicas passíveis de serem habitáveis.

No entanto, a subversão constituinte do impersonagem de Pool tem seus limites, pois a normatividade do "masculino" e "feminino" e a sua correspondente corporeidade não são totalmente superadas ao passo que as diferenças entre esses dois polos persistem.

\subsubsection{A personagem ausente e a narrativa em Pool (no water)}

Ela morreu? Suponho que, por um momento, isso passou pela minha cabeça, e eu pensava - não, ela não morreu. E acho que, de algum modo, nós sabíamos que ela não tinha morrido. Ela "tinha passado do estado de consciência".

E a grande coisa ausente está deitada aos nossos pés [...]." ${ }^{{ }^{69}}$

A personagem ausente de $P o o l$ não só influencia como domina a peça e os demais personagens. Quando o dramaturgo inclui essa figura que não é vista por nós e à qual os demais personagens apenas se referem, a finalidade é motivá-los assim como transformálos. Ela não é apenas uma amiga que está sendo lembrada e que, portanto, restringe a sua existência apenas a esse modo. A personagem que nós não vemos no palco, ainda assim, está presente. Porque ela motiva os demais personagens a agirem e a tomarem um certo

\footnotetext{
${ }^{68}$ BUTLER, 2004, p. 2.

${ }^{69}$ Did she die? I suppose for a moment it crossed my mind and I was - no she didn't die and I think somehow we knew she didn't die. She 'passed from consciousness'. And the great absent thing is lying at our feet [...]. (RAVENHILL, 2006, p.303)
} 
rumo, fazendo avançar o enredo. Mas a presença física dela é, à primeira vista, desnecessária. E a sua ausência pode torná-la ainda mais significativa porque a conhecemos apenas por inferência.

Daryl Gonder (2001, p. 11) em sua tese de doutoramento defende que, enquanto Freud considera a ausência como um "paradigma psicológico", dramaturgos veem nesse elemento um modo importante para "a construção dos demais personagens, da narrativa e da peça em geral". Na dramaturgia, um personagem ausente se refere a um tipo de personagem que jamais aparece fisicamente sobre o palco, mas que é motivo dos diálogos entre os personagens em virtude do profundo efeito que exerce sobre as ações.

Ignorar os desdobramentos causados nas ações da peça Pool pela personagem ausente é subestimar a estrutura teatral inteira da peça. Nos termos do pesquisador Bryan Garner (2001, p. 88), a "causa aproximativa" [proximate cause] é capaz de criar um evento que, sem ela, não ocorreria. Apesar de não aparecer no palco, a personagem ausente serve como esse tipo de causa para todas as ações. Além desse papel, essa figura, de certo modo, não representada, exerce também outras funções, como a de dissemelhança com os demais personagens. O sucesso dela, por exemplo, contrasta com o fracasso profissional dos demais. E a sua profunda influência sobre os personagens gera um efeito de passividade e paralisia neles. Ela também funciona, ao final, como uma figura salvadora para aquelas vidas angustiantes. Nos momentos de total miséria e perda de esperança, os personagens presentes anseiam pela personagem ausente e pela salvação que ela possa lhes trazer. O grave acidente ocorrido na piscina lhes possibilita extravasar sentimentos até então contidos, assim como propicia um final em chave positiva: os personagens tornam- pais/mães de famílias e livram-se dos males da vida boêmia.

Possivelmente, outra função importante da personagem ausente é a de intensificar a empatia entre os personagens sobre o palco e o espectador na plateia ou o leitor. Como 
os personagens A, B, C e D, os espectadores tendem a se tornar perplexos com o mistério que ronda a personagem ausente. Há uma relação, não apenas de inveja e ciúmes, que se constrói ao longo do enredo, mas, também, de culpa nessa dialética entre a personagem ausente e os seus pares, presentes: uma espécie de dor autoinfligida e constituinte desse laço entre a fotógrafa bem-sucedida e os seus velhos amigos.

Uma série de acontecimentos relacionados às ações ocorridas no palco são, numa relação de causa e efeito, iniciadas e motivadas pela personagem faltante. A integridade estrutural da peça entraria em colapso, o centro do conflito se perderia e os catalisadores da ação possivelmente desapareceriam se a personagem abstraída, de repente, subisse ao palco. Nessa peça centrada em torno da ausência, a personagem cria um sentido de presença, paira sobre a maioria das ações e impulsiona os conflitos. Funcionando como um "outro", essa personagem guia as ações e contribui significativamente para o desdobramento dos episódios criados ao longo do enredo.

Essa ausência conecta-se a um centro que é constantemente deslocado a fím de formar aquilo que Michel Foucault (1972, p. 13) denomina de "centro da consciência". Patrick Fuery, em seu livro The Theory of Absence (1995), defende que, apesar de significar o oposto da presença, a ausência atua como uma formadora de um tipo particular de presença. Fuery ainda afirma que o ausente é figurado como alguém potencialmente vivificado, ou seja, "mantido em prontidão" 70 [held in readiness], sempre à espreita.

Em Pool, a personagem é descrita por meio indireto. Os personagens no palco falam sobre ela frequentemente, sobre suas qualidades e fragilidades e, assim, trazem-na,

\footnotetext{
70 Op. cit., p. 2.

Nessa obra o autor investiga a dialética e o modo de funcionamento relacionados ao caráter de ausência e ao pensamento pós-estruturalista.
} 
sempre, de volta ao palco. A marginalização por meio da ausência dessa personagem é posicionada contraditória e forçosamente ao centro do enredo.

Além disso, se, por um lado, os diálogos sobre a personagem apartada causam um elo, uma conexão, entre os personagens presentes e o público, por outro, também geram dúvidas, pois nos deixam sem saber se o ponto de vista escolhido é confiável em vez de distorcido. No mínimo, pode-se afirmar que são contraditórios, pois há momentos em que ela é "amada" e em outros "odiada". Ao passo que os personagens reconhecem cada vez mais a importância da "outra" personagem por meio da centralidade que ela assume em suas narrativas, as contradições do texto se tornam cada vez mais aparentes. Os personagens ora a condenam, ora a absolvem pela prática antiética e imoral de exibir fotografias de amigos em estado de fragilidade e, assim, ganhar fama e dinheiro. Talvez, nada do que dizem seja sincero quando observamos o modo como os personagens a tratam quando ela está hospitalizada.

Esteticamente, a ausência da personagem distancia o sujeito, dispersa o centro da ação e expande o significado da narrativa ${ }^{71}$, enquanto solicita a participação do leitor/espectador invocando a sua imaginação ${ }^{72}$. Nos termos de Gonder (2001, p. 16), a paradoxal "presença ausente" de um personagem excluído do palco atrai a nossa atenção para essa personagem como um meio de buscar o propósito da narrativa presente na peça. Parece evidente que os espectadores formam uma imagem mental da personagem faltante baseada no modo como os demais a descrevem. Em virtude de a sua voz não ser ouvida

\footnotetext{
${ }^{71}$ Elinor Fuchs (1985, p. 165) afirma que "o teatro da ausência dispersa o centro, desloca o sujeito e desestabiliza o significado".

${ }^{72}$ Por sua vez, Ernst Gombrich (1961, p. 179) afirma que a ausência como um procedimento teatral apela para "a participação do espectador".
} 
e ela permanecer silenciada ao longo do enredo, a personagem abstraída não pode aceitar ou refutar o modo como os outros a enquadram ${ }^{73}$.

Essa personagem não está simplesmente condenada ao silêncio, mas, sim, à oscilação entre a presença e a ausência. Como se estivesse sempre à beira da presença, em virtude de suas características, ela se mantém num espaço transicional entre a ausência e a presença, e se encontra tanto fora quanto dentro da estrutura da peça. A personagem não apenas contribui para os conflitos e o desenvolvimento do enredo, mas, também, constitui-se num centro focal do espetáculo, assumindo um significado simbólico. Em Pool, conforme avançamos no desenvolvimento do enredo, cada vez mais, a ausência ganha status de presença a ponto de a ausência e a presença tornarem-se indistinguíveis. Isso se materializa, sobretudo, na montagem de estreia da peça, no momento em que os quatro personagens passam a se revezar no papel da "amiga" deitada no leito do hospital enquanto os demais a "torturam".

Relacionados à personagem ausente, os significantes são construídos a fím de oferecerem uma subforma da presença ou um senso de verdade por meio do processo de mediação e contemplação da figura ausente pelos demais. Em termos mais gerais, uma pessoa ausente, por exemplo, deleita-se com a sua condição de ausência, simplesmente, porque a sensação da presença se mantém em prontidão, em estado de existência ${ }^{74}$. Em Pool, a personagem abstraída transforma-se aos poucos no centro das atenções. A falta dela determina os significados da narrativa, direcionados para uma ausência e/ou para uma presença, por meio da sua condição de "não-estar".

\footnotetext{
${ }^{73}$ Segundo Paul Rosefeldt (1996, p. 3), "embora todos os personagens no teatro estejam sujeitos à interpretação dos outros personagens, o personagem ausente é diferente porque esse tipo de personagem não pode explicar as suas ações, como tampouco pode contradizer a representação que outros constroem. O personagem ausente, então, transforma-se em um outro que passa a ser refletido e refratado por meio do ambiente dramático".

${ }^{74}$ Ver FUERY, op. cit., p. 2.
} 
Essa descentralização do sujeito não implica a negação ou o aniquilamento do sujeito "tradicional”. Terry Eagleton (1985, p. 70) afirma que o pós-modernismo não confunde "a desintegração de certas ideologias tradicionais acerca do sujeito com o desaparecimento final do sujeito". Esse conceito, aplicado à prosa de ficção, pode também servir ao teatro, pois peças como $P o o l-$, bem como $S F$, - são, de certa maneira, narrativas encenadas.

Assim como em Pool, consciência, moralidade, ganância, inveja, ciúmes e crenças constituem vozes capazes de influenciar consideravelmente nossas vidas. Além dos diálogos, Ravenhill usa outros mecanismos voltados para a simbolização da personagem "central", como imagens visuais ou sonoras. Na montagem de estreia, o cenário idealizado como o fundo de uma piscina vazia ocupa todo o palco por onde os personagens transitam e falam, muitas vezes em discurso direto, como se fossem a própria personagem ausente. E, quando essa personagem está internada no hospital, A, B, C e D se revezam, obcecados, exercendo o papel da paciente acamada.

A personagem ausente mantém durante a peça traços permanentes da sua identidade, como um lembrete da influência exercida sobre os demais personagens. Esse "marcador icônico"75 é, por exemplo, representado pela piscina sem água. Mesmo ausente, ela ocupa grande parte da conversa entre os personagens, e o cenário fixo, representado pela piscina, funciona como sinal da onipresença da "fotógrafa famosa".

A piscina serve como um lembrete da diferença social e econômica existente entre ela e os demais, e como a marca do evento que aproxima "o grupo". No que tange às descrições narrativas presentes na peça, a personagem abstraída funciona como um gatilho que evoca o passado e a remove da ação presente. Ela impulsiona os demais a

\footnotetext{
${ }^{75}$ Nos termos de Rosefeldt (1996, p. 3)
} 
tomarem o curso das ações. Eles falam, movem-se e gesticulam porque a sua ausência é a causa disso. Em sua presença, as ações seguiriam outro caminho.

Quando a fotógrafa bem-sucedida é hospitalizada, os personagens se revezam, deitando-se no leito que, no cenário, instala-se dentro da piscina. Essa espécie de ressureição da personagem moribunda por meio da encarnação sob a pele dos demais lhe confere o domínio da expressão dos personagens. Assim, a personagem é evocada no palco, num primeiro momento, por meio do diálogo que recupera a memória e o passado e, num segundo, por meio da corporeidade encarnada nos demais. Por ser invisível e interpretada a partir de pontos de vista conflitantes - ora endeusadores, ora endemoniadores -, seu empoderamento oscila entre forças distintas tanto destrutivas quanto construtivas. Ela é a origem tanto do ódio, da inveja e da ganância quanto da inspiração dos demais que, a partir desses dois polos, têm a ideia de registrar aquele momento, fotografando a sua recuperação e seu estado de vulnerabilidade. Conforme a personagem faltante se aproxima da morte, ela ganha mais vida, corporificando-se nos outros personagens.

A personagem abstraída é estruturalmente eficaz ao estabelecer essa contrariedade entre ausência e presença. $\mathrm{O}$ espelhamento dela nos demais personagens funciona como a causa de toda a ação existente. Ela é o resultado de uma construção formal que parte tanto de dentro quanto de fora da estrutura dramática. Esse discurso constituído da ausência para a presença e vice-versa pode ser interpretado como a oscilação do discurso entre a periferia e a centralidade das formas: entre um tipo de personagem tradicional do teatro e um outro, incomum.

Essa personagem ora está presente nas ações ora nas descrições narrativas realizadas nas falas dos demais personagens. No início e no fim da peça, sua presença é (narrativamente) descritiva. Durante a sua recuperação depois do acidente, a personagem 
se corporifica por meio dos demais e se insere na ação. Todavia, essa constatação só é válida se pensarmos sobre a montagem original de Pool, de cuja concepção Ravenhill participou. Se nos debruçarmos apenas sobre o texto, veremos que a existência da personagem ausente ocorre principalmente de maneira descritiva. Na montagem original, essa relação entre, de um lado, a presença da personagem por meio de descrições narrativas realizadas durante as falas de A, B, C e D e, do outro, por meio desses mesmos personagens que a corporificam se revezando deitados no leito de um hospital (simbólico), posicionado no fundo da piscina vazia, exacerba o contraste entre a personagem ausente e os personagens-letra.

A personagem faltante, ao assumir com os demais personagens uma relação de causa e efeito, respectivamente, acaba exercendo mais influência neles do que qualquer outro fator. Descrita como uma referência artística e bem-sucedida, ela é abstraída do palco tanto por ter se tornado aquilo que os outros não são (famosa e rica) quanto por refletir uma consciência culpada dos demais.

Devotos da fotógrafa, os personagens a idolatram, falando dela o tempo todo. A personagem ausente é capaz de trazer tanto alegria e amor, assim como, quando isso se perde, ódio e vingança à vida dos demais, que partem para um comportamento retratado como insano. No hospital, eles a estupram, sugere a montagem de estreia da peça.

A centralização a partir da ausência sugere que tanto os personagens sobre o palco quanto os espectadores juntam-se numa busca pela personagem abstraída a fim de revelar a sua identidade. Apesar da sua ausência, a personagem atua como uma força propulsora das ações: a partir dela agem A, B, C e D. Ignorar a sua importância causaria à peça uma fratura estrutural tão grave quanto a de um mergulho numa piscina vazia. A personagem funciona como o gatilho ou a causa para as ações e, sem ela, a peça perderia não só a sua vivacidade, como, também, a sua estrutura formal. 
Nesse universo fetichizado de Pool, a imagem de sucesso da "amiga" não oferece escapatória aos personagens que se voltam inteiramente para aquilo que ela simboliza. A experiência estética resultante desse jogo entre ausência e presença é indissociável de uma afronta à ideia de indivíduo e de individualidade percebida nos personagens-letra, que acabam por estetizar esses momentos de desaparecimento da pessoa e de sua transformação em mercadoria. Em vez de uma imagem contraposta à da personagem ausente, os demais personagens tornam-se a imagem refletida do mercado, algo que pressupõe a ausência de reflexo de si mesmo, vivendo e ajustando-se segundo as exigências do sistema a fim de desfrutar de suas promessas.

\subsubsection{Afinal, quem são os personagens de Mark Ravenhill?}

Nas duas peças, os personagens compartilham, por meio de ações inverossímeis, certas características em comum: uma espécie de ambivalência entre o vínculo afetivo e a motivação financeira ${ }^{76}$. Fatos habituais são encenados de um modo "estranhado", criando o efeito que Brecht denomina Verfremdungseffekt ${ }^{77}$. Esse efeito de estranhamento, segundo Pavis (2008, p. 119), "mostra, cita e critica um elemento da representação, ele o descontrói, coloca-o à distância por sua aparência pouco habitual e pela referência explícita a seu caráter artificial e artístico". É o estranhamento que possibilita a quebra do envolvimento emocional entre o espectador e o personagem característico do teatro ilusionista.

\footnotetext{
${ }^{76}$ Por sua vez, segundo Pallottini (2015, p. 38), "verossímil" significa, em suma, que "ao autor dramático cabe dar tal organização ao seu material que tudo, praticamente tudo, ali, uma vez preparado, devidamente proposto, adequadamente introduzido, adquire foros de credibilidade, fica possível, torna-se aceitável". ${ }_{77}$ Verfremdungseffekt, ou efeito $\mathrm{V}$, expressão alemã traduzida de forma não literal como efeito de estranhamento.
} 
SF e Pool mostram que, mesmo num mundo em que tudo e todos estão aparentemente à venda, a preocupação com o bem-estar das pessoas próximas é capaz de emergir nos lugares mais improváveis, apesar das oportunidades envolvendo ganhos financeiros criar uma atmosfera inteiramente egoísta. A conclusão de ambas as obras também indica que, no teatro e na vida, a distinção entre os papeis de opressor e oprimido pode se dar em diversas vias. Gary, de $S F$, por exemplo, obriga Mark, personagem este que o ama, a satisfazer o seu desejo de morrer, o que culmina numa espécie de clímax da peça: o estupro de Gary, seguido por um provável esfaqueamento, consensualmente realizado, sobretudo, por Mark e Robbie. Essa cena cria uma situação na qual Gary é tão vitimizado pelas circunstâncias quanto os demais personagens que foram levados a fazer algo que também os aterrorizava.

Do mesmo modo, a personagem ausente de $\mathrm{Pool}$ sintetiza essa fronteira nebulosa e cambiante entre a figura do tirano e do tiranizado. No hospital, quando a personagem é exposta às lentes fotográficas e à violência, inclusive sexual, dos demais personagens, a cena também condensa o horror dos personagens em realizar algo que, muito possivelmente, não queriam. No entanto, a possibilidade de comercialização das fotos documentando o processo de recuperação da paciente famosa mostra-se financeira e inquestionavelmente vantajosa para todos os envolvidos. O estímulo econômico é a motivação dos personagens tanto carrascos quanto vítimas na primeira e na segunda peças. No entanto, os personagens A, B, C e D de Pool, assim como Brian-o personagem mais velho de $S F$-, revelam ser muito mais ambiciosos do que os personagens jovens de SF: Lulu, Mark, Robbie e Gary. Ou seja, a motivação da competitividade e do acumulo capitalista se acentuam em Pool, havendo uma deterioração ainda maior das relações, a ponto de as personagens se "desintegrarem" ou se fundirem em um coletivo indiscriminado e amorfo. 
Nas relações de força existentes em $S F$ e Pool, há algo de mais complexo do que a polaridade entre, de um lado, a parte opressora e, de outra, a oprimida. Mais explicitamente revelado em Pool, quando os personagens se revezam no leito do hospital, cometendo e sofrendo agressões, o comportamento e a reação de A, B, C e D frente às agressões cruéis e repetitivas tornam a violência tanto fisicamente palpável quanto intolerável. ${ }^{78}$

Na comparação entre uma peça e outra, a caracterização dos personagens se radicaliza. Contudo, o "personagem”, tanto em $S F$ quanto em Pool, como defende Renata Pallottini (2013, p. 158), quando analisa a construção dos personagens no Teatro do Absurdo, "tem como ponto de referência, o ser humano, por mais deformado, retorcido, estilizado que possa ser. Segundo Sarrazac (2017, p. 156), no teatro contemporâneo, a identidade dos personagens é algo vacilante: difratada ao infinito, ou reduzida ao extremo, ela não é senão a presença de um ausente, ou a ausência de um presente - numa espécie de "mimese por falta". Nesse processo, em vez de singularidade, revela-se algo de fantasmagórico, de morto-vivo, como uma representação do que nos é comum em nossa vida social, e que aproxima o dramaturgo do espectador.

Terminologias, como a de "impersonagem"79, sinalizam um desconforto em definir essas figuras como instâncias de linguagem que circunscrevem a reconstrução de biografias imaginárias e estáveis, corpos coerentes e inteligíveis ou personalidades distintas, seguramente localizadas no espaço e no tempo. Esses paradigmas são importantes não só como sistemas classificatórios, mas também apontam para questões de suma relevância.

\footnotetext{
78 Vale lembrar novamente que, na montagem original da peça, não há um personagem exclusivo que represente a fotógrafa: todos os personagens se revezam no papel dela.

79 SARRAZAC, 2017, p. 147.
} 
No entanto, a questão essencial por trás da manutenção do termo "personagem" mesmo diante de "figuras" não-individualizadas é a nossa crença no potencial ético e político maior de se expandir, por meio desse termo consagrado, a amplitude da experiência teatral. Fuchs (1996, p. 8), identifica o termo "personagem" como detentor de um significante relacionado ao modo como a nossa percepção do "ser" se transforma na passagem de um momento histórico para o outro, e como essas mudanças são centrais para os modos como os movimentos culturais se articulam ao longo do tempo.

As peças $S F$ e $P o o l$ apresentam a dor física como uma perturbação da unidade, da individualidade. Esse processo é articulado por meio de um tipo de "violência em estado puro" contra identidades e corpos a fim de substituir (ou, ao menos, desmascarar) "o simulacro de uma representação" por acontecimentos em que a vida e a morte estejam em jogo, de acordo com o que defende Jean-Jacques Roubine (2003, p. 169) acerca de peças cuja influência é o "teatro do sacrifício"80.

\subsection{A quebra de ilusão nos cenários de Shopping and Fucking e Pool (no water)}

Em $\boldsymbol{S F}$, multiplicidade de cenários e a concomitante ausência, na encenação, de seus elementos constitutivos contribuem para reafirmar o estranhamento, além de solicitar a imaginação do público e contribuir, pela abstração, para elevar o singular e o local ao universal. Os cenários, segundo a rubrica, são reduzidos ao mínimo de objetos. Há nisso certa desmaterialização, algo de irreal, que se infiltra a fim de causar o estranhamento. As várias alternâncias entre os cenários (o apartamento de Robbie, Lulu e Mark, o flat de Gary, o escritório de Brian, a sala de espera do pronto-socorro etc.)

\footnotetext{
${ }^{80}$ Segundo Roubine (2004, p. 69), "há apenas uma maneira de arrancar o teatro de suas irrisórias rotinas miméticas, pensa Artaud: redefinir sua vocação como uma experiência dos limites", substituindo "o simulacro de uma representação por um acontecimento real em que a vida e a morte estariam em jogo".
} 
acentuam esse caráter frenético da vida contemporânea, da ação de sujeitos que se deslocam incessantemente com a expectativa de sobreviver, que estão sempre em trânsito, circulando, assim como as mercadorias e o capital financeiro.

A pluralidade de ambientes insere no universo tradicionalmente dialógico [do drama] certo caráter narrativo ${ }^{81}$. Vale lembrar que outros ambientes entram no universo da peça por meio das "estorinhas": a da balada eletrônica, a da loja de conveniência, a da loja de rede fast-food etc. E, ademais, a homogeneidade visual desses ambientes, reduzida ao essencial na montagem do cenário, preenchido por uma ou outra mobília, rompe a ilusão ${ }^{82}$ cênica e nos faz ver toda essa mudança de ambientação como algo quase estático, que muda para permanecer igual.

Por sua vez, na montagem de estreia de Pool, a convergência, no palco, entre elementos cênicos que representam uma piscina esvaziada e um quarto de hospital resultam numa composição capaz de enfraquecer o pacto e a unidade ficcional. A cama hospitalar posicionada no fundo de uma piscina vazia, na montagem de estreia, atrelada à ausência de rubricas no texto original, atesta não só o esvaziamento simbólico do cenário, algo que se relaciona ao título da peça - Piscina (sem água), na tradução literal - mas, também, ao fato de que as amizades e as práticas artísticas se revelam vãs, vazias, assim como os conceitos inerentes a esses signos.

\footnotetext{
${ }^{81}$ Segundo Szondi (2001, p. 33), no drama "algo análogo [à demanda dramatúrgica pela unidade de tempo] no que se refere ao espaço fundamenta a exigência de unidade de lugar. $O$ entorno espacial deve (assim como os elementos temporais) ser eliminados da consciência do espectador. Só assim surge uma cena absoluta, isto é, dramática. Quanto mais frequente são as mudanças de cena, tanto mais difícil é esse trabalho [grifo nosso]. Ademais a descontinuidade espacial pressupõe o eu-épico".

82 "Graças à verossimilhança obtém-se a ilusão que permite ao espectador viver intensamente a ação cênica, esquecendo a sua condição particular" (ROSENFELD, 2008, p. 54).
} 


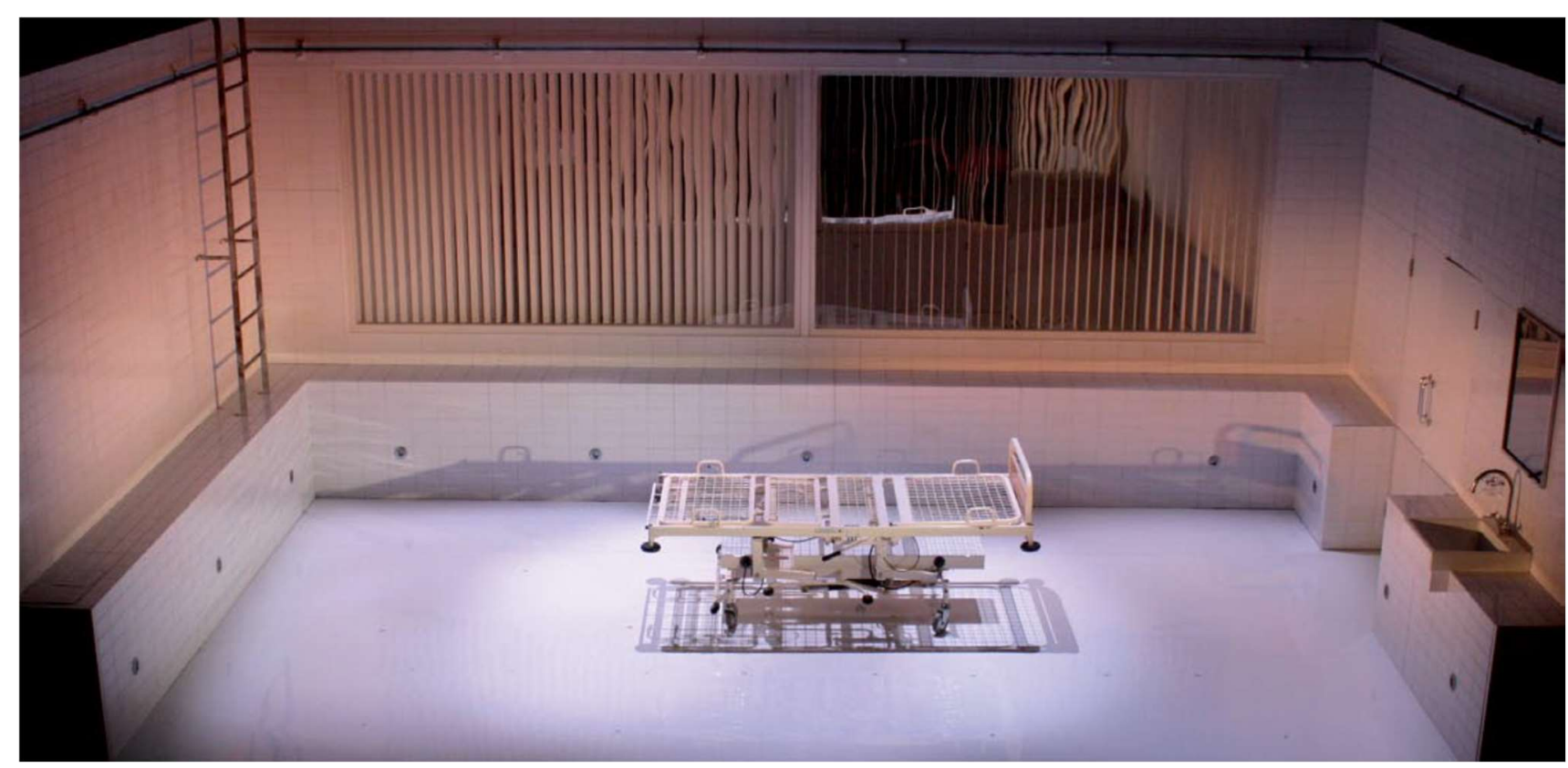

Imagem do cenário empregado no espetáculo original, desenvolvido por Miriam Buether. Disponível em https://www.franticassembly.co.uk/productions/pool-no-water. Acesso em 02 de janeiro, 2019.

\subsection{A transformação dos diálogos em Shopping and Fucking e Pool (no water)}

No teatro dramático, de acordo com Diderot ${ }^{83}$, falar é agir, no sentido de que as falas produzem uma ação que faz a narrativa caminhar e o diálogo, por sua vez, efetivarse. Em vez de levar a vida para frente, uma outra dimensão do diálogo costuma levar, em $S F$, a vida a um giro em falso e, em Pool, para trás.

Em larga medida, ambas as peças podem ser enquadradas naquilo que Sarrazac ${ }^{84}$ denominou de "infradramático", forma esta que não substitui o dramático mas que amplia o seu espectro, deslocando "o centro da relação interpessoal para o homem só, o homem separado, isolado". Esse "paradigma” está ligado à observação dos aspectos do cotidiano, que se projetam na forma por meio do isolamento dos personagens. Nesse sentido, há nas duas peças analisadas neste trabalho, um dialogismo de menor dimensão denominado,

\footnotetext{
${ }^{83}$ Entre os preceitos do drama burguês encontram-se o diálogo intersubjetivo, o personagem psicologizado, as relações particulares e a estrutura enrijecida da fábula, com seu percurso de acontecimentos extremamente codificado (DIDEROT, 2005).

84 “O infradramático não substitui o dramático: ele amplia o seu espectro; desloca o centro da relação interpessoal para o homem só, o homem separado, isolado" (SARRAZAC, 2017, p. 58).
} 
segundo Sarrazac (2017, p. 205), de "polílogo" que, em peças como as de Beckett, é compatível com um "homem separado", por sintetizar uma espécie de solidão "polifônica" 85 dos personagens, resultante "da perda da comunidade e do desejo contrariado de constituí-la":

A partir do momento em que uma dramaturgia do homem ordinário quer dizer, da espécie humana e da espécie humana dada como perecível, e até mesmo suscetível de aniquilar-se - suplanta a dramaturgia das grandes personagens, cada indivíduo é tido como capaz de conter toda a humanidade. Eis por que todos esses personagens, esses impersonagens que falam no "vazio", sem se comunicar entre eles [...] parecem quase a totalidade humana representada em cena.

Em SF e Pool, essa instância do diálogo encontra-se entremeada por descrições narrativas e criam uma tensão entre um movimento do drama para frente, que persiste, e uma força de resistência, até mesmo contrária, que se impõe e que resulta num movimento de "desdramatização" ${ }^{86}$. A análise do funcionamento desses diálogos redimensionados nos ajuda a entender os diferentes significados resultantes de uma interferência que remete nessas duas peças a um recurso tipicamente épico. Essa presença residual do épico, em SF e Pool, funcionaria como um “contrapeso" necessário ao dramático ${ }^{87}$.

\footnotetext{
85 "Palavra solitária polifônica, o polílogo de Beckett é o resultado da perda da comunidade e do desejo contrariado de constituí-la" (SARRAZAC, 2017, p. 208).

${ }^{86}$ Segundo Sarrazac (2007, p. 21), "o desvio por essa teoria do contrapeso - desvio [este] que muito provavelmente foi feito por Brecht, nos permite melhor compreender o que há da desdramatização, da tensão entre um movimento do drama para a frente, que persiste, e uma força de resistência, até mesmo contrária, que vem se interpor".

${ }^{87}$ Sarrazac desenvolve uma "teoria do contrapeso", em que, entre períodos de tensão dramática, podem se intercalar períodos de relaxamento pertencentes ao épico. Assim, uma peça não precisaria ser mais escrita em função do seu fim, numa tensão crescente em direção ao seu desfecho (ibidem, p. 20).
} 


\subsubsection{As "estorinhas" em meio aos diálogos de Shopping and Fucking}

No início da primeira cena, Robbie, Mark e Lulu estão no apartamento em que vivem juntos tentando se alimentar de uma comida pré-pronta e insossa. A partir disso, um processo de contação de "estórias" realizada pelos personagens passa a nortear a peça: “Conta pra gente a estória ${ }^{\mathbf{8 8}}$ das compras”, pede Lulu a Mark (2001, p. 4):

Mark: você está vendo aquele par ao lado do iogurte? Então, diz o homem gordo, ambos são meus. Eu os possuo. Eu os possuo, mas não os quero mais - porque, você sabe de uma coisa? Eles são lixo. Lixo, e eu os odeio. Quanto custam? Um resto de lixo como eles... digamos que uns \$ 20. Isso mesmo. Eles são seus por \$ $20^{89}$ (RAVENHILL, 2001, p. $5)$.

Na continuação dessa narrativa, subentende-se que Mark teria passado a viver com Robbie e Lulu após tê-los comprado desse "homem gordo", alegoria esta do sistema econômico que rege o mundo de compras e vendas em $S F$. Entremeadas no universo real da peça e nos desafios que cada personagem enfrentará a fim de continuar subsistindo, as “estórias" aos poucos se multiplicam. Na cena 5, Lulu descreve a Robbie uma estória/situação que teria vivenciado numa loja de conveniência, na qual um morador de rua ataca a atendente do estabelecimento com uma faca enquanto ela aproveita para afanar uma barra de chocolate. Na cena 6, Gary conta a Mark sobre um sangramento resultante dos abusos que costumava sofrer do padrasto. Mark não quer dar ouvidos à estória e reage

\footnotetext{
${ }^{88}$ Negrito nosso.

89 'Mark: [....]See the pair by the yoghurt. Well, says fat guy, they're both mine. I own them. I own them but I don't want them - because you know something? - they're trash. Trash and I hate them. Wanna buy them? How much? Piece of trash like them. Let's say ... twenty. Yeah, yours for twenty."
} 
agressivamente, desejando evitar qualquer "envolvimento": "PARA, CARALHO! QUER

CALAR A PORRA DESSA BOCA?". 90

No início da cena 7, Robbie está machucado e sangrando. Lulu o encontra numa enfermaria de hospital. A garota pede que Robbie lhe "descreva", "como uma estória", o episódio do acidente enquanto ela o masturba. Robbie não está com o dinheiro correspondente à venda das drogas e muito menos com o ecstasy que deveria ter vendido para ajudar Lulu em seu novo "emprego". Ele o teria distribuído aleatória e gratuitamente e, por isso, acabou apanhando de pessoas que ficaram insatisfeitas quando souberam que as drogas tinham acabado. Defendendo-se, agora, da rejeição manifestada por Lulu, procura argumentar a respeito do fato de tê-las doado:

Eu estava vendo esse planeta de cima. Astronauta sobre a terra. E, aí, eu vi essa criança em Ruanda chorando sem saber por quê. E aquela senhora em Kiev vendendo absolutamente tudo que tinha acumulado na vida. E esse presidente em Bogotá ou... Na América do Sul. E vi o sofrimento. E as guerras. E as pessoas tomando, tomando, tomando umas das outras. E eu penso: foda-se o dinheiro. Nada de vender. Nada de comprar. Nada de sistema. Foda-se essa porra desse mundo e vamos ser... lindos. Lindos. E felizes. (RAVENHILL, 2001, p. 39) ${ }^{91}$

Falas como essa revelam emoções, mesmo que, muitas vezes, de maneira irônica, banalizada, e mostram como o personagem conta com um excesso de informações desencontradas, que desorganizam o raciocínio a ponto de torná-lo extremamente

\footnotetext{
${ }^{90}$ FUCKING SHUT UP OK? KEEP YOUR FUCKING MOUTH SHUT. (Grafia em letras maiúsculas no original.)

${ }^{91}$ I was looking down on this planet. Spaceman over this earth. And I see this kid in Rwanda, crying, but he doesn't know why. And this granny in Kiev, selling everything she's ever owned. And this president in Bogota or ... South America. And I see the suffering. And the wars. And the grab, grab, grab. And I think: Fuck Money. Fuck it. This selling. This buying. This system. Fuck the bithcing world and let's be ... beautiful. Beautiful. And happy.
} 
superficial. O trecho serve de crítica à "era da informação"92 em que, embora tenhamos cada vez mais acesso a imagens, notícias, artigos etc., somos aparentemente incapazes de filtrá-los, selecioná-los, e de estabelecer entre eles relações capazes de se tornarem verdadeiramente esclarecedoras acerca de nossa sociedade. O personagem faz aproximações disparatadas entre fatos desproporcionais, relacionando guerras e miséria extrema a fim de justificar o seu comportamento na festa para, ao final, concluir justamente com o mote central do mundo contemporâneo: sejamos "felizes". Os elementos presentes nessa descrição narrativa inserida em meio aos diálogos acabam sendo os mesmos de cenas anteriores: as vendas, as compras, as drogas, o excesso de informações desencontradas, a fragmentação, a superficialidade e, uma certa, escassez.

Na cena 8, novamente interessa mais o trecho narrativo, ou a descrição de algo que é narrado em meio aos diálogos e que não vemos se desenvolver, no palco, na forma de ação: o personagem Gary continua falando sobre a sua relação traumática e violenta com o padrasto e da tentativa de buscar ajuda do aparato público:

Fui até uma assistente social. E disse pra ela: "Olha, é muito simples: ele tá me currando. Uma, duas, três vezes por semana, ele vem no meu quarto. [...]. “Quanto tempo faz isso?”, ela pergunta. [...]. E, então, ela diz: "Ele usa preservativo?" (p. 40) ${ }^{93}$

Sem se importar com o cerne da questão, a assistente social acaba circundando o problema sem tomar medidas diretas: “ela diz [...]: 'Dê a ele esse folheto'. [...]. O que é

\footnotetext{
92 Cf. JAMESON, 1997.

93 [...]. I went to the council. And I said to her, look, it's simple: he's fucking me. Once, twice, three times a week he comes into my room. [...]. How long? she says. [...]. I told her and she says 'Does he use a condom?'
} 
que pode resolver a porra de um folheto?”, diz Gary (p. 41) ${ }^{94}$. Em oposição a esse "padrasto", Gary diz haver um "cara" que irá lhe "pegar e levar pra a sua mansão".

Contra a violência da vida e do espaço privados, a contrapartida da assistência pública é ridicularizada, mostrando que o Estado de bem-estar social não durou para sempre $^{95}$. A descrição de ambas as esferas realça tanto o sentimento de inércia e inexistência do serviço público quanto o de agressão e imposição do mundo privado; se este agride, aquele não age: "Aí ela me olha... com pânico nos olhos, e diz: 'O que é que você quer que eu faça?"”. De um lado, existe a figura do padrasto violento, enquanto do outro, a de alguém supostamente protetor (sobre isso, falaremos mais adiante). Fechando a cena, Gary mostra a Mark uma sacola cheia de moedas, sugerindo-lhe tê-las ganhado na casa de jogos, e o convence $a$ ir às compras enquanto faz as moedas tilintarem entre os dedos e a palma da mão, deleitando-se com a sonoridade produzida, segundo a rubrica.

Na cena 10, em um desdobramento da cena anterior, Lulu e Robbie falam incessantemente ao telefone com seus clientes da linha de telessexo que acabaram de montar. Os dois personagens estão presentes, falando com interlocutores ausentes e não narrando estórias do passado mas inventando em tempo real novas estórias, fictícias numa variação dessas narrativas presentes em meio aos diálogos.

Na cena 12 ocorre um processo de síntese e convergência dos elementos vinculados às descrições narrativas anteriores: uma espécie de colagem em que velhas estórias são recuperadas e ajudam a compor novas estórias a partir das anteriores ou,

\footnotetext{
${ }^{94}$ You know what she says. [...] Give him a leaflet.[...]What good is a fucking leaflet?

${ }^{95} \mathrm{Na}$ Inglaterra, a reorganização produtiva - o fordismo - contribuiu para a formação do Estado de bemestar social [Wellfare state] que perdurou, aproximadamente, do final da Segunda Grande Guerra até os anos 1970 e promoveu a redução vertiginosa do desemprego, além de garantir direitos sociais aos trabalhadores. Essas medidas, oriundas de pesados déficits orçamentários, transformaram-se em melhoras expressivas para a classe operária, fortalecendo suas organizações e seus sindicatos. O capitalismo, assim, parecia ter eliminado suas contradições. O Estado de bem-estar social, baseado em técnicas keynesianas de controle da economia, mostrava indícios de uma fórmula que aparentava ter dado ao capital uma feição mais "humana", mais social. (MANDEL, 1990, p. 27)
} 
ainda, recompô-las. Lulu, exausta e assustada, desliga a linha de telessexo e diz a Robbie que um rapaz teria feito o seguinte comentário sobre a agressão de que foi vítima a atendente da loja de conveniência, fato este narrado na cena 5: "ele diz que está se masturbando com esse vídeo de uma mulher, uma estudante que está numa loja de conveniência Seven-Eleven, trabalhando no caixa. E que entra um bêbado e... então..."96. Assim, retoma-se a narrativa em que Lulu descreve a Robbie ter presenciado o mesmo ataque descrito, dessa vez, por um dos seus clientes da linha de telessexo que está visualizando o episódio em um vídeo. Essa via das descrições narrativas também expõe, na peça, mais uma característica das "relações sociais entre pessoas" que, cada vez mais, "torna-se mediada por imagens", nos termos de Guy Debord (1997, p. 14), mecanismo este que, em $S F$, ajuda as estórias a se multiplicarem.

Mais do que pelas ações que exercem ao longo do enredo, a caracterização dos personagens passa obrigatoriamente pelas suas próprias narrativas, presentes na peça em meio aos diálogos. Na cena 13, com exceção de Brian, todos se reúnem para um jogo narrativo do qual Gary se tornará o protagonista. Trata-se de uma estória fantasiosa que, porém, resultará na provável morte real do personagem, o que aponta, mais uma vez, para a convergência entre ficção e realidade no universo da peça. É possível constatar o descaso de Gary em relação às possibilidades de mudança de rumo em sua vida. A cultura do consumo "desperta nos consumidores a fantasia de deixar a rotina e a monotonia para trás sem lhes oferecer qualquer meio de empoderamento capaz de viabilizar esse percurso" (ROJEK, 1995, p. 107). As mensagens de fuga vinculadas ao consumo acabam tendo o efeito adverso, acentuando cada vez mais o conformismo e a monotonia, em vez

\footnotetext{
${ }^{96}$ Op. cit., p. 61. And I mean, he is wanking to this video of a woman, a student girl who's in the SevenEleven, working behind the counter. And there's a wino and ... yeah.
} 
de oferecer aos indivíduos oportunidades genuínas de expressão. Gary vê na morte a sua única saída.

Em uma das cenas mais longas, Mark, primeiro, descreve um encontro sexual no banheiro de um restaurante, e, então, a sugerida morte de Gary - já que ela não se concretiza em cena. No palco, os supostos sujeitos daquela ação específica - Robbie, Lulu e Mark - aceitam matar Gary em troca de um pagamento oferecido por esse mesmo personagem. Volta à narrativa o "homem gordo", presente na abertura, e que, nessa nova estória, passa a ser o "proprietário" de Gary. No final, Gary insiste novamente, como no início da peça, em sua necessidade de ter um pai:

$$
\begin{aligned}
& \text { Gary - Você é ele? Você é meu pai? } \\
& \text { Mark - Não. } \\
& \text { Gary - É sim. Você é meu pai. }{ }^{97}
\end{aligned}
$$

Mark resiste em fazer as vezes dessa figura que teria de assassinar Gary. Mas ambos acabam saindo de cena juntos, o que sugere a morte de Gary nas mãos de Mark.

Na cena 14, inesperadamente, a dívida de Robbie, Lulu e Mark é perdoada. Brian deixa de lhes cobrar o dinheiro que corresponderia à venda das drogas, algo que remete à entrevista de emprego de Lulu ainda no início da peça, quando ela assume o compromisso de fazê-lo. Como na cena 9, Brian insere no videocassete um filme que mostra o filho tocando violoncelo e, em seguida, mais um, com as imagens de Lulu, sem camiseta, durante a entrevista. E, assim, procura justificar as suas ações, resumindo a lógica da

\footnotetext{
${ }^{97}$ Op. cit., p. 83.

Gary - Are you him? Are you my dad?

Mark - No.

Gary-Yes. You are my dad.
} 
sociedade de $S F$ : "Nós temos que trabalhar. Tudo que temos a fazer é ganhar dinheiro. Pra eles"98. E sai de cena após relembrar um episódio do filme Rei Leão:

Brian - Nesse momento ele já está casado. E tem um filho seu. Bem no final ele está só. Ele está sobre uma pedra e observa a noite, olha para cima, para as estrelas, e diz: "Pai. Tá tudo bem, pai. Eu lembrei. O Ciclo da Existência". Ou outras palavras com esse efeito. Vocês deveriam assistir. Vocês iriam gostar. (Brian sai e Mark se levanta.) (p. 89) ${ }^{99}$

E, então, Mark começa a narrar uma espécie de ficção científica pornográfica em que recupera, pela terceira vez, a estória do homem gordo que agora é dono de um mutante superdotado sexualmente. Na narrativa, Mark compra o mutante e o liberta: "Estou te deixando livre. Você pode ir agora"100. A recuperação incessante de cenas e narrativas mostra uma espécie de padrão presente no nível formal da peça.

Mark diz, no papel de mutante, dentro da "estorinha": "Eu morro. Por favor. Não posso... Fui escravo durante toda a vida. Não sei como... Não consigo arrumar comida sozinho"101. De modo metafórico, o personagem fala de si mesmo, de seus pares e também dos e para os espectadores. Em seguida, é feito o encadeamento rumo ao fim da peça. Quanto à estória/narrativa acima, Lulu conclui: "Eu gosto desse final ${ }^{102}$ ".

É essa tensão entre real e fictício que também alicerça a peça. Pois reais são as frustrações, como a falta de dinheiro, de perspectiva, de afeto, além da fome constante. Como os pares Beckettianos, os personagens aqui se agrupam por "inércia", em uma

\footnotetext{
${ }^{98}$ Op. cit., p. 88. We must work. What we've got to do is to make the Money. For them.

${ }^{99}$ Because by then he's got married. And he's got a kid on his own. Right at the end he stands alone. He's on a rock and he looks up at the night, he looks up at the stars and he says: 'Father. Everything is alright, Father. I remembered. The Cycle of Being.' Or words to that effect. You ought to see it. You'd like it Exit Brian. Mark comes forward.

100 I'm setting you free. You can go now.

${ }^{101}$ Please. I'll die. I don't know how to... I can't feed myself.

102 Negrito nosso a fim de salientar tanto o padrão formal quanto os termos usados que são típicos de narrativas convencionais contendo início, meio e fim.
} 
solidão coletiva apaziguada pela presença física dos "parceiros". Fictícias, por outro lado, são as soluções para os desapontamentos: o encontro desprezível e fácil entre Mark, Robbie, e Lulu por meio da estória de compras em um supermercado; o dinheiro conquistado sem dificuldades no telessexo, o sexo com celebridades em um banheiro de bar na estória de Mark, o perdão da dívida no discurso inverossímil de Brian; a solução para a falta de alternativas na vida de Gary por meio de um jogo narrativo, resolvido com uma morte prazerosa por penetração e esfaqueamento, ou o deslocamento dos personagens para um outro planeta, narrado por Mark, no último capítulo, quando a Terra se encontra devassada pelo sistema.

Os momentos de "realidade" são desvirtuados a todo instante pelo sexo aleatório ou virtual, pelas drogas, pela televisão, além de, é claro, pelas “estorinhas", meros paliativos para a falta de sentido reinante no palco.

\subsubsection{O diálogo voltado para o passado em Pool (no water)}

Esta peça, contendo uma única e longa cena, tem uma forma inusual de "diálogo difuso" em que, como mencionado, não são especificadas as falas de cada personagem ou quantos personagens são necessários a fim de se compor o elenco. As falas são enunciadas sem que se saiba quem o faz.

Segundo Ravenhill, Pool trata basicamente de uma estória contada à plateia por quatro personagens, ou, em outras palavras, o diálogo existente naquela obra é, sobretudo, com a plateia $(2006)^{103}$ :

\footnotetext{
${ }^{103}$ The play I've written is largely a story told by the four performers to the audience, and the actors are starting to miss the interplay that dialogue gives them. As we reach break time, I try to assure them that there is a dialogue going on in the writing - only it's with an audience (http://www.theguardian.com/stage/2006/sep/20/theatre1).
} 
A peça escrita por mim é majoritariamente uma estória ${ }^{104}$ contada pelos quatro atores aos espectadores, e os atores estão começando a sentir falta do jogo interno que o diálogo lhes dá. Quando chegamos ao intervalo, eu tento lhes assegurar que há um diálogo acontecendo na escrita - só que ele é com a plateia.

Possivelmente encarando os espectadores, dizem-nos os personagens: "uma piscina, ela tinha uma piscina. De todos nós ela é - pelo menos, aos olhos desse lugar chamado mundo - a mais bem-sucedida entre nós"105 (p. 295). Há apenas alguns momentos, segundo a disposição visual dos diálogos, em que os personagens podem, dependendo das escolhas de montagem dessa peça, estar dialogando entre si:

Então - uma piscina.

Ela quis nos impressionar? Era para se mostrar?

Não, eu não acho. Não. Porque ela é... Ela é boa. Ela é legal. Ela tem integridade. Ela tem raízes.

E ela tem uma piscina agora - Isso é fantástico fantástico fantástico fantástico ${ }^{106}$.

Segundo Rosenfeld (2008, p. 56), a direção ao público é sintoma da tendência épica, por não ser propriamente o personagem que se dirige ao público, mas o ator como porta-voz do autor, isto é, como narrador que não se identifica por inteiro com o papel. A direção explícita para o público tende também a interromper a situação dialógica entre os personagens. Apesar de as vozes poderem estar distribuídas entre diversos personagens,

\footnotetext{
${ }^{104}$ Negrito nosso a fim de destacar a ideia de "estória" ou narrativa, como gênero, que se insere formalmente nos diálogos em ambas as peças.

105 A pool, she had a pool.

Of all of us the most - at least in the eyes of this so-called world - the most successful of us.

${ }^{106}$ So-a pool.

Did she mean to impress? Was it for show?

No. I can't think. No. Because she's...

She's good. She's nice. She has integrity. Her roots.

And she has a pool now. It's fantastic fantastic fantastic fantastic.
} 
a sequência do pensamento pode ser considerada, até certo ponto, linear, como se falada por uma mesma pessoa, um pensamento único, atribuído a um único personagem: isolado, solitário em meio a um grupo.

Num certo sentido, essa peça é heterogênea quanto à extensão das falas: trechos menores e mais abruptos, e outros em que as falas são mais longas. Aparentemente, segundo o texto dramatúrgico, pode-se especular que a fala mude de personagem quando o texto intercala ou pula uma linha em branco antes da fala seguinte. Como no exemplo a seguir:

Ela é incansável ao nos ajudar com as nossas atividades para captação de recursos.

(linha em branco, no texto original)

Nós a adoramos. Nós a adoramos. Nós todos a adoramos.

(linha em branco, no texto original)

As linhas acima podem ser, nas montagens, enunciadas por personagens diferentes, pois há uma linha de espaço entre elas, mas não há, em forma de rubrica, qualquer indicação a esse respeito. Cabe notar ainda que o ritmo das falas ganha em aceleração e intensidade conforme a peça progride, e os personagens presentes no palco se mostram cada vez mais próximos dos espectadores e distantes dessa amiga. De maneira fragmentada e difusa, sem interlocutores claros, provendo várias recordações/narrativas do passado, formatadas em blocos de relato, os diálogos, aos poucos, constroem o enredo indo e voltando no tempo.

A peça termina com a informação de que, dois anos depois e apesar do constante abuso antes e durante o período da narrativa apresentada, o grupo está "limpo das drogas e os seus integrantes formaram, cada um, as suas famílias” (2008, p. 323): 
E, agora. Os anos se passaram. E olhe para os meus braços - sem marcas do passado - nada. Limpo. E esses quatro aqui - dentes novos. Lindos.

E, por falar nisso, eu encontrei alguém de que eu realmente gosto, e eu tenho dois filhos - um deles tem dois anos, e o outro, quatro - e eles gostam de mim, e isso é o que faz tudo parecer muito melhor. Porque, quando todos nós estamos nos divertindo na piscina infantil, as coisas parecem ok. E as crianças têm os seus próprios telefonezinhos - pra segurança -, e eles gostam de tirar fotos da mamãe deitada na piscina. E isso é carinhoso. ${ }^{107}$

Nota-se, aqui, a amplitude de encerramento, onde se passam as descrições narrativas: a projeção de uma amizade, tal como se estivesse ali representada a maior parte da vida, de maneira resumida, condensada, característica esta que, em grande medida, representa o paradigma definido por Sarrazac de "drama-da-vida". Segundo Sarrazac (2017, p. 74), esse “advento do drama-da-vida está, portanto, ligado à possibilidade ou à impossibilidade de inscrever o tempo, a duração de uma vida inteira no espaço do drama". Além disso, a presença constante da amiga famosa nas falas dos personagens realça a distância entre os mundos vistos sobre o palco e um outro imaginário, do qual eles não fazem parte.

Enquanto a personagem ausente está hospitalizada e se recuperando dos traumatismos que sofreu, após a queda na "piscina sem água", um personagem nos informa (2008, p. 317):

\footnotetext{
${ }^{107}$ And now. Years have gone. And look at these arms - no track marks - nothing. Clean. And these four here-new teeth. Beauties.

And I actually met someone who I rather like and I have two children - one is two, the other is four - and they like me so that makes it feel rather better. Because when we're all playing around the paddling pool things seem rather okay. And the children have their own little mobile phones - for safety - and they like to take pictures of Mummy lying in the pool. And that's lovely.
} 
Mas realmente nós sabemos. Nós sabemos que essa estória ${ }^{\mathbf{1 0 8}}$. A estória dela. As fotos. É isso que eles estão fazendo. Vendendo. Formatando. Promovendo. Lançando. Eles estão se preparando para o dia do lançamento. ${ }^{109}$

Os amigos do grupo fotografam os momentos da recuperação dela, a cicatrização das feridas etc. Sem se importar que, ao final, o resultado seja "sem sentido"110:

Bem, mesmo que em pedaços de - grandes pedaços de, na verdade capítulos inteiros de - alguns momentos chaves de - mesmo que "leiame" tivesse, na verdade, ferrado com a estória da cura dela, então, agora, ela se curou de uma hora para outra e começa - uma narrativa ${ }^{111}$ sem sentido.

Mais próximo do fim, os personagens expressam a vontade de que o "grupo" um dia se reencontre, apesar de isso lhes parecer quase impossível. E o caráter de isolamento dos personagens por uma via menos usual, até então, a de projeção de um futuro virtual e nada provável e, portanto, distante da realidade presente é ressaltado:

E eu gosto de pensar na possibilidade de haver um centro de reabilitação ou um pavilhão para os doentes de Aids, ou algum lugar em que possamos estar juntos de novo. Algum lugar onde nos encontraremos e seremos uma gangue. Mas - ei, eu sou uma romântica. Eu estou cada vez mais bobona, velha e romântica conforme os anos passam. ${ }^{112}$

\footnotetext{
${ }^{108}$ Negrito nosso a fim de realçar como a ideia de "estória" está presente tanto na forma quanto no conteúdo dessa peça.

${ }^{109}$ But really we know. We know that this story. Her story. The pictures. This is what they are dealing in. Selling. Packaging. Promoting. Launching. They are getting ready for the launch day.

${ }^{110}$ Well even if chunks of - great big chunks of actually - whole chapters of - some key bits of the - even if 'read me' had actually fucked up the story of her healing so now she healed in leaps and starts - a nonsense narrative.

${ }^{111}$ Negrito nosso a fim de realçar como a presença das narrativas surge tanto na forma quanto no tema.

112 And I like to think there's a rehab or an Aids ward or a somewhere where we'll be together once again. Somewhere where we'll meet and be the gang. But-hey I'm a romantic. I'm a foolish old romantic as the years go on (RAVENHILL, 2008, p. 323).
} 
Como uma "estória", pincelada com elementos de sentimentalismo, os personagens descrevem aparentemente de maneira "subjetiva" os acontecimentos. No plano da ação física, os personagens podem, muitas vezes, como seres autômatos, robotizados, correr, pular e se contorcer assim como permanecer estáticos em alguns momentos. Quando se trata de ação não física, a influência do passado, motivada pelo sentimento de vingança, é algo tão forte que os impede de agir.

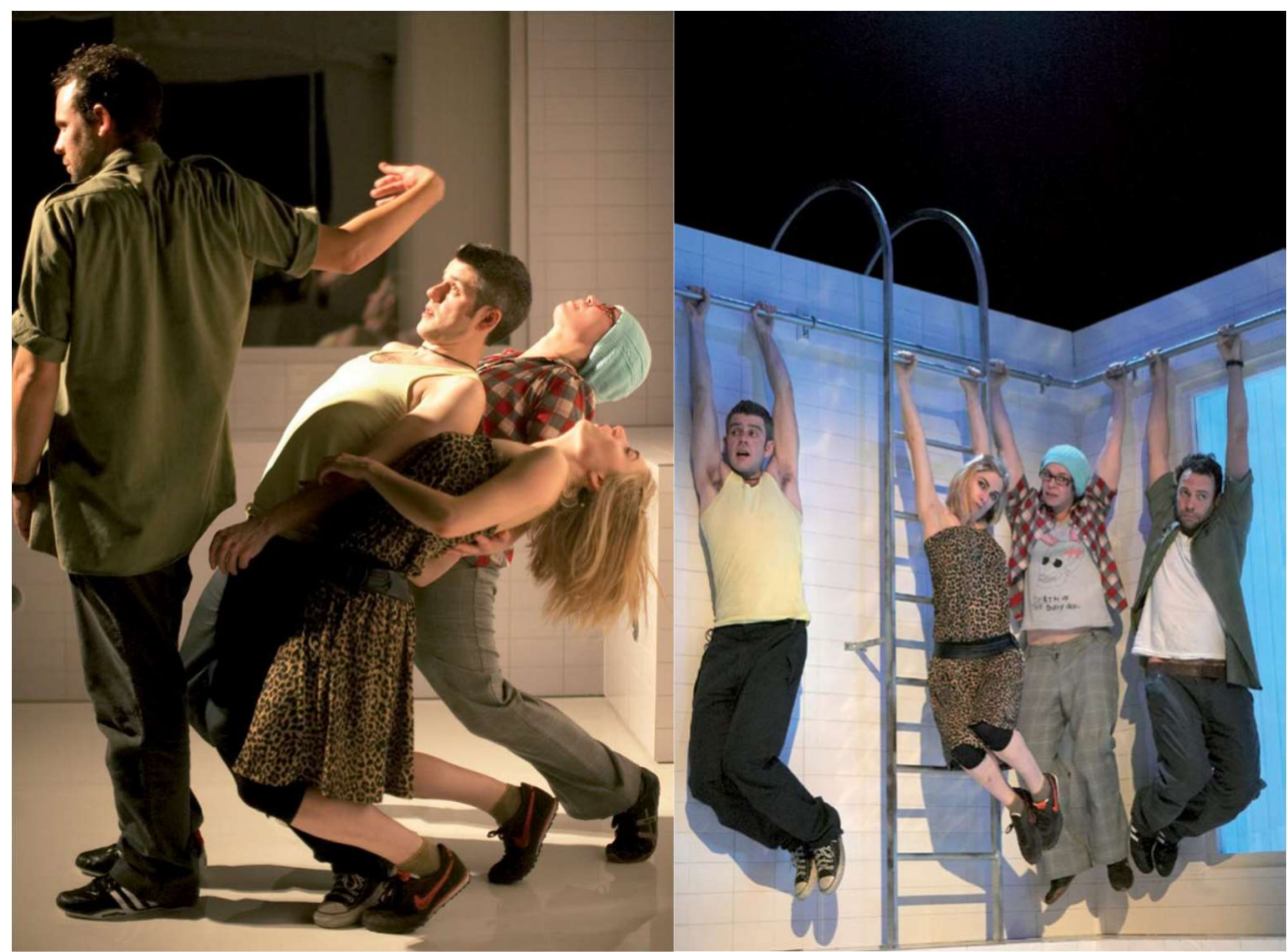

Imagens da montagem de estreia de Pool. (Atores em cena: Keir Charles, Cait Davis, Leah Muller e Mark Rice-Oxley, na foto de Manuel Harlan.)

Em Pool, a narrativa termina em tom de superação das diferenças e num registro irônico: "Então. Acenda as velas. Asse o bolo. Cante as músicas. A gangue está toda aqui. Nós estamos aqui juntos. E o sonho é sonhado, e, ufa, a vida é longa"113. Muitas vezes, alternando orações na primeira e na terceira pessoas do singular: "eu" e "ela",

${ }^{113}$ So. Light the candles. Bake the cake. Sing the song. The gang's all here. We're here together. And the dream is dreamy and oh life is long. (RAVENHILL, 2008, p. 323) 
respectivamente, assim como na terceira do plural: "nós", há um interessante jogo entre “eu" e "nós" em contraposição a "ela", resumido no exemplo a seguir: "e é como se nós fossemos capazes de ouvi-la dizer - a boca dela está fechada, mas ainda assim eu, nós, eu nós, ouvimos"114. (Note-se a aproximação entre o "eu" e o "nós" por meio da exclusão da vírgula, o que aproxima os termos visualmente.) No entanto, o que mais se nota é a distância intransponível entre o universo virtual da amiga famosa, presa ao passado, e o universo real dos personagens que, de maneira ainda mais radicalizada na comparação com $S F$, encontram-se agrupados no tempo presente da encenação por uma falta de sentido e uma pobreza (material/espiritual) comum a suas vidas e que só pode ser amenizada pela presença física dos demais. Os bons tempos, a alegria e a diversão fazem parte do passado e/ou de uma projeção virtual enquanto do presente e da realidade afloram sentimentos como a solidão, a angústia, a inveja, o rancor e a ilusão de sucesso e enriquecimento.

Quando consideramos o cenário em que se encontram esses personagens - no fundo de uma piscina vazia -, tornam-se ainda mais virtuais/ilusórias as soluções que levam ao final feliz dessa "estória" e, portanto, da peça. A piscina, assim como a vida dos personagens, está esvaziada de sentido.

\subsubsection{Nós, todos, precisamos de estórias}

Não disse isso. Eu acho... Eu acho que tudo que nós precisamos são estórias. [...] Eu acho que tempos atrás tinha grandes estórias. Histórias tão grandes que você podia passar a vida toda só acreditando nelas. A “Poderosa Força das Mãos de Deus e seu Destino". "A Viagem do Esclarecimento". "A Marcha do Socialismo". Mas elas todas morreram,

\footnotetext{
${ }^{114}$ Op. cit., p. 322.
} 
ou o mundo amadureceu ou envelheceu ou se esqueceu delas, e então nós agora estamos inventando nossas próprias Histórias. Estorinhas. Cada uma de um jeito. Mas cada um de nós tem a sua. (2001, RAVENHILL, p. 66) $)^{115}$

Essa fala do personagem Robbie, no diálogo célebre de $S F$, descreve a passagem ou "uma transição cultural das narrativas arquetípicas [ou grandes estórias] e crenças compartilhadas rumo a inumeráveis estórias individuais", afirma o professor e crítico norte-americano de literatura e teatro Thomas Horan (2012, p. 252), em seu artigo intitulado Myth and Narrative in Mark Ravenhill's Shopping and Fucking ["Mito e narrativa em Shopping and Fucking de Mark Ravenhill”, na tradução literal]. O comentário feito por aquele personagem possivelmente sugere que as grandes narrativas eram capazes de nos causar um senso de empatia, união e progresso social, e que, sem as estórias épicas, esses valores teriam se tornado simplesmente inalcançáveis.

A fala "Não disse isso. Eu acho... Eu acho que tudo que nós precisamos são estórias [...]. Estorinhas. Cada uma de um jeito. Mas cada um de nós tem a sua." ${ }^{116}$, pode ser interpretada à luz da teoria do filósofo francês Françoise Lyotard (1984), autor este que, além de reconhecer, nas últimas décadas, uma atrofia presente nas grandes narrativas, discorda da ideia de que essas mesmas narrativas teriam em algum momento da História propiciado uma espécie de sentimento de coesão social. Lyotard afirma que "alguns autores" acreditariam no término das grandes narrativas e na dissolução dos laços sociais, bem como no fato de que essa desintegração social nos teria transformado numa massa de átomos individuais e limitada à existência aleatória. Segundo esse teórico (1984, p. 15),

\footnotetext{
${ }^{115}$ I didn't say that. I think ... I think we all need stories, we make up stories so that we can get by. And I think a long time ago there were big stories. Stories so big you could live your whole life in them. The Powerful hands of God and Fate. The Journey to Enlightenment. The March of Socialism. But they all died or the world grew up or grew senile or forgot them, so now we're all making up our own stories. Litlle stories. It comes out in different ways. But we've each got one.

${ }^{116} \mathrm{O}$ trecho em questão é citado na íntegra na abertura desse subcapítulo.
} 
nada disso seria cabível, pois tal ponto de vista estaria "assombrado pela representação paradisíaca de uma sociedade 'orgânica' perdida”, afirma ele.

Em virtude da possível aproximação conceitual entre as falas do personagem de $S F$ e a do filósofo, o dramaturgo Mark Ravenhill e, por extensão, os seus contemporâneos do movimento In-yer-face podem passar uma impressão de certo desinteresse pela situação social cruel e degradante à qual os seus personagens se subjugavam. Segundo o crítico teatral inglês Graham Saunders (2008), o fato de a sociedade, em seu estágio atual, não mais enunciar as grandes narrativas que, nas gerações anteriores, circulavam livremente, impediria a vinculação das pessoas a um corpo social, uma comunidade, e essa seria uma característica comum não apenas evidente em peças como $S F$ e Pool, mas, também, em todo o In-yer-face ${ }^{117}$. A professora de estudos teatrais Elizabeth Sakellaridou $(2008 \text {, p. 4) })^{118}$, do departamento de inglês, da Universidade Aristóteles de Salônica, é ainda mais incisiva ao afirmar que o movimento $I Y F$ refletiria o colapso das grandes narrativas, de maneira generalizada, em nossa vida social: "acredito que seja a hora de aceitarmos como definitiva a queda das 'grandes narrativas', mesmo no mundo do teatro".

No entanto, esses apontamentos desconsideram algo essencial. Como veremos mais adiante, a presença de certas (macro-)narrativas em peças explicitamente perturbadoras, como $S F$, estabelecem unidade estrutural e coerência temática, assim como despertam em seus espectadores um sentimento moral e de esperança, algo que, por outro lado, não garante aos personagens um senso de pertencimento a uma comunidade ou a um corpo social. O personagem Brian (RAVENHILL, 2001, p. 46), por exemplo,

\footnotetext{
117 Segundo Graham Saunders (2008, p. 3) "as micronarrativas parecem ter dominado a maior parte da dramaturgia produzida a partir de meados dos anos 1990".

${ }^{118}$ Citado em SAUNDERS, op. cit., p. 4.
} 
espécie de microempresário e pequeno traficante, expressa valores tradicionais, voltados para a família:

Outrora era o Paraíso, entende? E era possível ouvir isso - o Céu cantando na frente dos nossos olhos. Mas nós pecamos, e Deus tirou isso de nós..., mas, às vezes, nós recebemos um sinal - uma música ou um poema -, o que nos faz lembrar de como [a vida] era antes de todos os pecados ${ }^{119}$.

O discurso sinestésico sobre Deus, o Paraíso e o colapso da humanidade pode ser lido como uma ironia à tese de que, um dia, as grandes narrativas teriam sido capazes de tornar a vida mais coerente e as pessoas mais unidas, na medida em que estabelece equivocamente uma relação nostálgica com o tempo passado. De modo similar, supor que a perspectiva de Robbie ou de qualquer outro personagem sobre as narrativas possa de alguma maneira representar o ponto de vista do dramaturgo Mark Ravenhill também é um erro.

Rebellato (2001) ${ }^{120}$ salienta a importância de não descontextualizarmos a fala de Robbie (citada na abertura desse subcapítulo), endereçada naquele momento ao personagem Gary porque, apesar de a peça nos apresentar um universo dominado e estraçalhado por valores que se associam à ordem econômica, os personagens relutam em aceitar plenamente o modo de vida que lhes é imposto. O dispositivo utilizado por Ravenhill a fim de rejeitar a fragmentação social, sugerida naquela fala de Robbie, encontra-se na importância central das narrativas como um todo, narrativas esta que, por

\footnotetext{
119 "Because once it was paradise, you see? And you could hear it - heaven singing in your eyes. But we sinned, and God took it away ... but sometimes you get a sort of glimpse-music or a poem-and it reminds you of what it was like before all the sin."

${ }^{120}$ Esse crítico assina a introdução do primeiro volume de peças do dramaturgo Mark Ravenhill publicadas pela editora inglesa Methuen Drama.
} 
meio das "estorinhas" ou micronarrativas acabam conectando, sem distinção, os próprios personagens.

A interação em nossa vida social feita por meio das micronarrativas, como sugere Robbie em sua fala durante a interação com Gary, enraíza-se numa tendência de privatizar e reificar até mesmo os nossos pensamentos mais íntimos. O professor de literatura em língua inglesa Christian Schmitt-Kilb (2005, p. 199), da Universidade de Rostock, na Alemanha, defende que a privatização do conhecimento público e a guinada [na peça $S F$ ] em direção às "estorinhas" não são um possível revés do "efeito totalizante das grandes narrativas mas, sim, expostas como a ideologia do capitalismo global e irrestrito que impossibilita qualquer modo de resistência" ${ }^{21}$.

Ravenhill é um autor comprometido com interesses coletivos, e não individuais. E, no contexto geral, a apresentação das ideias dúbias de Robbie acerca das "estorinhas", endereçadas tanto ao personagem Gary quanto (indiretamente) aos espectadores, inserese possivelmente entre uma parcela significativa de ataques irônicos feitos por esse dramaturgo a uma mentalidade consumista típica dos nossos tempos. Mais do que a expressão de um desejo de refúgio em suas micronarrativas, os personagens de Ravenhill acabam por sugerir que o conjunto formado por suas "estórias" seja capaz de ajudá-los a atribuir sentido a um mundo desordenado, caótico. Em Pool, o fato de os personagens terem uma caracterização fluída acaba deixando a "narrativa" que é a peça muito mais coesa e unificada, causando a impressão de que as estórias distribuídas entre A, B, C e D sejam, em essência, uma narrativa geral/maior.

${ }^{121}$ SCHMITT-KILB, C. "Lifestyle Anarchism and Its Discontents: Mark Ravenhill, Enda Walsh and the Politics of Contemporary Drama." In: To Hell with Culture: Anarchism and Twentieth-Century British Literature. Ed. Gustav Klaus and Steven Knight. Cardiff: U of Wales P, 2005. 
Em vez de considerar a dramaturgia de Ravenhill repleta de micronarrativas, a crítica teatral inglês Caridad Svich (2003, p. 81) acredita que o trabalho desse dramaturgo britânico dialoga diretamente com as peças típicas da antiguidade: “as peças de Ravenhill são movidas por um impulso moral que as conectam a uma tradição de escrita mais clássica em sua natureza e pouco reconhecível para muitos leitores".

Embora as suas peças não sigam os padrões do teatro grego, muitas das grandes narrativas estabelecidas durante aquele período aparecem na sua obra, como veremos logo adiante. Ravenhill também se apropria das narrativas populares da Inglaterra, vinculadas à tradição oral. Sierz (2008, p. 24), por exemplo, afirma que "num nível, $S F$ reconta o mito "Babes in the wood" ${ }^{122}$ [Bebês na floresta] e, que, portanto, evoca, mesmo que de maneira generalista, essa antiga narrativa, capaz de ser imediatamente reconhecida pelo espectador britânico. Tais narrativas também emergem quando a peça é examinada em detalhes: os personagens conhecem a tipologia básica oriunda do cristianismo. E Lulu é capaz de enunciar passagens canônicas da peça As três irmãs, de Anton Chekhov ${ }^{123}$. De maneira mais significativa, o diálogo de Robbie e Lulu com os clientes da linha de telessexo revela a familiaridade deles não apenas com a mitologia clássica mas também com a sua relevância para os dias atuais:

Lulu: Alô? Nome, por favor. E o seu número. Ah. Galope. Sim, galope aceleradamente, garanhão dos pés flamejantes, rumo à pousada de

\footnotetext{
${ }^{122}$ Babes in the Wood é uma fábula tradicional inglesa e comumente representada em peças teatrais infantis até os dias de hoje. Nela, duas crianças abandonadas numa floresta, morrem e são cobertas com folhas por algumas aves conhecidas como pintarroxos, típicas da Grã-Bretanha. A fábula pode ser gratuitamente acessada em: http://www.gutenberg.org/ebooks/19361?msg=welcome_stranger

${ }^{123} \mathrm{Na}$ entrevista de emprego com o personagem Brian, na cena 2, Lulu diz (RAVENHILL, 2001, p. 13): "darei aulas em uma pequena escola e vou devotar toda minha vida àqueles que necessitam de ajuda" (citação da fala da personagem Irina, em Três irmãs, de Chekhov, ato I,). [I'll teach in a school and devote my whole life to people who need it.]
} 
Febo! Um condutor como Faetonte chicotearia.... Sim... Espalhe teu... Bom, isso mesmo (RAVENHILL, 2001, p. 52). ${ }^{124}$

Nesse momento, Lulu e o cliente anônimo mostram-se familiarizados com o mito greco-romano de Faetonte ${ }^{125}$, estória esta sobre um menino cujo desejo de ser reconhecido e aclamado por uma figura paterna e opressora se associa a um desejo de morte. Apesar de, como leitores/espectadores, estarmos vinculados apenas a um lado dessa conversa, as referências de Lulu à narrativa de Faetonte, intercaladas por supostas réplicas, tréplicas e estímulos positivos dessa mesma personagem, como, "Sim. Sim. Bom. Bom."126, sugerem que o interlocutor dela, supostamente posicionado do outro lado da linha telefônica, não se surpreendeu com as referências a um texto canônico feitas pela personagem.

Esse modelo nebuloso da relação entre pai e filho, apresentados em termos míticos por meio da estória de Faetonte, aparece de maneira recorrente ao longo de $S F$, criando vínculo com a tradição do teatro ocidental, não apenas em relação à estrutura, mas, também, aos temas, que possuem uma dose latente de otimismo.

De acordo com o mito antigo, mais reconhecidamente transmitido por Ovídio, na obra Metamorfoses (2001, p. 24-34), Faetonte é filho de Febo - o deus do Sol - com Clímene, uma mortal. Duvidoso de sua origem paterna, Faetonte, ao encontrar Febo, confronta-o. Então, a fim de comprovar o laço paterno entre ambos, essa divindade promete realizar o desejo do filho, que almeja conduzir a carruagem do Sol em direção ao céu por um único dia. E, para isso, unta o menino com um óleo mágico capaz de suportar o calor solar e concretizar o desejo inconsequente do garoto.

\footnotetext{
${ }^{124}$ Hello? The name? And the number. Ah. Gallop. Yes. Gallop apace you fiery-footed steeds toward Phoebus' lodging! Such a waggoner as Phaeton would whip . . Y Yes . . . Spread thy . . Good, that's right. ${ }^{125} \mathrm{Na}$ citação ipsis litteris de Romeu e Julieta, de Shakespeare, no ato 3, cena 2, feita pela personagem Lulu de $S F$.

${ }^{126}$ Yes. Yes. Good. Good. (RAVENHILL, 2001, p. 52)
} 
Porém, Faetonte perde o controle da carruagem, e Zeus, na tentativa de impedir que, em virtude da imprudência do menino, a Terra se queime, aniquila-o com um raio. Desse modo, o deus dos trovões, chuvas, tempestades e raios impede uma tragédia, salvando a humanidade.

Nessa cena em que a personagem fala ao telefone, revela-se por meio da imediata identificação com o mito de Faetonte o compartilhamento entre Lulu e o seu (suposto) interlocutor de, pelo menos, uma grande narrativa. Esse mito, afirma Horan (2012, p. 256), "representa mais do que o de um menino em busca de uma espécie de estabilidade emocional proporcionada pela relação paternal e uma figura de autoridade”. Essa estória trata do desejo de um indivíduo que espera ultrapassar os limites e as regras socialmente aceitáveis num determinado tempo histórico. Num mundo governado por um panteão de deuses, muitas vezes caprichosos, Faetonte anseia ultrapassar as convenções impostas, aquecendo e iluminando toda a Terra. De modo muito semelhante, os jovens personagens de $S F$ buscam (ingenuamente) transcender a condição determinista da peça. (Em Pool, os personagens estão conformados e sem forças para lutar contra o sistema. E o sintoma mais evidente desse sentimento de derrota se encontra em suas falas voltadas quase integralmente para o passado revanchista.)

A evocação de Faetonte, na cena 11, indica que o dramaturgo retomou uma narrativa tradicional e que ela lhe permite criar um cenário desastroso sobre o qual ainda é possível incidir alguns raios de luz/esperança. Gary, assim como Faetonte, jamais deu forma ao rosto do pai ideal. Contudo, ele espera que Mark assuma esse papel e leve-o embora como o condutor de uma carruagem mágica. Nessa imagem recuperada de um jovem gracioso que é repentinamente raptado e, então, violentado por uma força divina, uma série de grandes narrativas se intersectam, como, por exemplo, a dos mitos de Ganímedes, Leda e Perséfone: 
Gary: Eu quero que isso acabe. E há apenas um final.

Mark: Eu entendo.

Gary: Ele não tem rosto na estória. Mas eu quero colocar um rosto nele.

O seu rosto.

Mark: Sim.

Gary: Faça isso. Faça isso, e eu lhe direi "eu amo você".

Mark: Certo. Você está dançando, e eu te levo embora (p. 85). ${ }^{127}$

Apesar de a cena não mostrar os desdobramentos desse diálogo, presume-se que Mark acaba matando Gary, pois esse personagem não aparece na cena final, e Robbie, nos derradeiros momentos, afirma que Mark tem marcas de "um pouco de sangue"128. Mesmo numa peça dominada pela imagem do sexo fácil, das drogas e da veneração do dinheiro, as grandes narrativas sutilmente persistem, atribuindo sentido à vida dos personagens e uma certa dose de esperança.

No nível discursivo, $S F$ funciona, de certa maneira, como um mito. A peça conta uma estória sedutora e capaz de oferecer uma certa ilusão confortante de coerência e encerramento em si mesma sobre personagens que buscam sair daquilo que acreditam se tratar das sombras, das trevas. São essas narrativas inseridas nos diálogos, e não apenas as representações de brutalidade próprias de um determinado tempo histórico, que separam em larga medida $S F$ de $P o o l$ e que transformam a peça de estreia de Ravenhill num trabalho paradigmático do movimento conhecido como In-yer-face.

\footnotetext{
${ }^{127}$ Gary: I want it over. And there's only one ending. Mark: I understand.

Gary: He's got no face in the story. But I want to put a face to him. Your face. Mark: Yes. Gary: Do it. Do it and I'll say "I love you." Mark: Alright. You're dancing and I take you away. 128 "a bit of blood", no original (p. 90).
} 


\section{A representação do corpo}

As imagens extremas de mutilação corporal se intensificaram nos anos 1990, e as peças teatrais desse dramaturgo são um meio particularmente usado para explorar a corporeidade. Ações de muitos artistas das chamadas body arts, e as suas ações deliberadas contra o próprio corpo tornam possível um espetáculo do corpo em sofrimento. No entanto, essa é uma dor na forma de experiência subjetiva e que apenas podemos observar de maneira segura, sem que seja possível compartilhar, por exemplo, a experiência de uma pessoa que costura seus próprios lábios ou se balança presa a ganchos atravessados na própria pele. Isso situa tais ações apenas num "nível individual narcísico", afirma Rebellato (2008, p. 205).

Nas cenas estudadas de Ravenhill neste trabalho, há uma análise mais fundamental a ser oferecida. Existe algo no modo como a produção de uma peça estabelece a relação entre as imagens existentes sobre o palco, a representação e os espectadores, de modo a intensificar essa experiência. O problema crucial, para tal teatro, é o da realização. Decerto, é mais fácil imitar a violência. Todavia, a simulação, percebida como tal pelo espectador, anula, segundo Roubine (2004, p. 173-4) "a eficácia sacrificial buscada"129. E o teatro recai, então, na ordem do mimetismo naturalista ${ }^{130}$.

Frequentemente narrada em vez de encenada, a violência é uma característica desse dramaturgo. Muitas vezes impossível de ser representada, seria, em outros casos,

\footnotetext{
129 "Tal teatro excede os limites de qualquer teatro. Sonha em tornar-se experiência vital, prova iniciática da qual o espectador sairia metamorfoseado e, de certa maneira, purificado a exemplo do fiel que participa dos sacrifícios prescritos por sua religião. Eis o tema da 'curação cruel', na terminologia artaudiana" (ROUBINE, 2004, p. 170).

${ }^{130}$ A reivindicação naturalista, finalmente, não é esse mimetismo integral ao qual não raro tentam vinculála. É bem antes o ressurgimento de uma permanente aspiração do teatro (e do público), a da ilusão da vida que se quer ver abundante no palco em oposição ao academicismo congelado, impotente para mascarar seus artifícios, a que conduzem, a cada época, uma utilização mecânica dos códigos e das convenções e uma perpetuação das tradições mais utilizadas. Cada geração, no fundo, experimenta a necessidade de inventar um novo sistema de convenções que dará, por um tempo, a ilusão da vida, antes de ser por sua vez percebido como tal e rejeitado em nome precisamente, da vida [...] (ROUBINE, 2004, p. 112-3).
} 
proibida por lei, caso o fato narrado se transformasse em objeto de encenação. A escolha, muitas vezes, pela descrição narrativa de atos violentos mantém o corpo íntegro enquanto sugere a sua mutilação. Em outras palavras, os atos de flagelo não coincidem com os corpos presentes e atuantes no palco.

A violência pode apresentar no espetáculo teatral tanto a mutilação de corpos quanto a persistência da não-mutilação, e essa relação se enfatiza em apresentações de peças em que a divisão não é meramente criada por meio ilusionista mas por escolhas envolvidas com a representação em si. Esse princípio teatral desenvolve um espaço e uma distância nos quais a corporeidade pode ser entendida e desafiada.

Imagens de flagelo corporal não são a rejeição de um engajamento político nem, necessariamente, uma maneira de inserir o espectador numa experiência instintiva, irreflexiva. As imagens, chocantes e imersivas, são capazes de carregar inúmeras implicações não-verbalizadas.

As peças $S F$ e Pool insistem em percorrer as sensações corporais, a fim de identificar onde, quando e o que sentem os seus personagens. Ravenhill procura refletir sobre os limites do corpo, as suas possibilidades de representação e a forma mediada pela qual nós nos conectamos com os nossos corpos e com os corpos de terceiros.

O mundo nessas peças é apresentado como espaço ocupado por discursos alienantes de poder. Ainda assim, significativamente, Ravenhill também teatraliza a direção oposta, mostrando indivíduos lutando para redescobrir sensações em "carne viva", a fim de localizar o real mesmo sob a influência mediadora da linguagem ou da presença agressiva da mídia e do consumismo. As suas imagens podem, então, ser vistas como suspensas e oscilantes entre as semânticas do discurso dominante e da tentativa de 
superação desse mesmo discurso. A continuação desse capítulo, portanto, procura analisar as ações físicas dos personagens em relação tanto ao conteúdo proposto quanto ao sentido do discurso nas peças.

\subsection{O corpo que não sente em Shopping and Fucking}

Em $S F$, o corpo das pessoas é visto como algo a ser temido; e o sangue, como objeto de desgosto e, por isso, quase inexistente. Na cena 2, Robbie é golpeado por um cliente que empunha um garfo de plástico:

Robbie - E tudo que eu disse foi: “com queijo, senhor?". E ele olha pra mim inexpressivamente. Só mira nos meus olhos. E há esse... medo. Tento de novo. "Você gostaria de queijo no seu hamburguer, senhor?". Isso é muito pra ele. Eu vejo o lábio inferior dele tremular. Os olhos estão enchendo de lágrimas. [...]

Robbie - E, então. Ele pega o garfo. Segura um garfo. E ele pula por cima do balcão. E ela vem pra cima de mim. [...]

Lulu - Ele te golpeou [com o garfo]?

Robbie - Não é nada

Lulu - Onde está o ferimento, então?

Robbie - Quebrou [o garfo]. Antes de fazer qualquer estrago. ${ }^{131}$

\footnotetext{
${ }^{131}$ Robbie - And all I've said was: With cheese, sir? And he just looks at me blankly. Just stares into my eyes. And there's this... fear. Try again. 'Would you like cheese on your burger, sir?' This too much for him. I see the bottom lip go. The eyes are filling up.

[...]

Robbie-And then. He gets his fork. Grab this fork. And he jumps over the counter. And he goes for me.

[...]

Lulu - He stabbed you?

Robbie - It's nothing.

$[\ldots]$
} 
A necessidade de Mark por outras pessoas se revela como algo perigoso:

Eu me agarro a alguém como que para afastar qualquer possibilidade de saber exatamente quem eu sou. O que é na verdade altamente destrutivo. Para mim... Destrutivo pra mim. $[\ldots]^{132}$

Sexo é considerado uma mercadoria, na visão desse mesmo personagem: "nós fizemos um trato. Eu paguei. A gente foi pro banheiro. Não significou nada"133. O personagem crê na possibilidade de que o ato sexual por ter sido pago nada significa. $\mathrm{Na}$ cena 4, enquanto os personagens Mark e Gary negociam o programa sexual, há um som de moedas tilintando, vindo do andar de baixo, onde funciona uma casa de jogos. A ação é interrompida quando Mark, com o rosto todo avermelhado e sujo, percebe que Gary está sangrando.

Na cena seguinte, também com o rosto manchado de sangue, Lulu se encontra com Robbie em um bar. Ao notar as manchas vermelhas, Robbie quer saber de Lulu o que houve. Segundo a garota, um "cara sujo, fedendo" atacava com uma navalha a atendente de um Seven-Eleven - rede de conveniência norte-americana bastante popular na Inglaterra -, enquanto Lulu, aguardando na fila do caixa para comprar uma barra de chocolate, aproveitou o rebuliço para sair de fininho sem pagar pelo produto. Na cena 10 , em um desdobramento da cena anterior, Lulu e Robbie falam incessantemente ao telefone com seus clientes da linha de telessexo que acabaram de montar.

Essa cena sintetiza o sentimento dos personagens e do universo de $S F$ em que tudo se tornou um simulacro da vida real (a imagem do sangue, escorrendo em diversas

Lulu-Where's the wound then?

Robbie - It snapped. Before it did any damage. (RAVENHILL, 2001, p. 14-5.)

132 Op. cit., p. 33. So I attach myself to others as a means of avoidance, of avoiding knowing the self. Which is actually potentially very destructive. For me-destructive for me.

${ }^{133} \mathrm{Em} S F$, cena 3. 
passagens, que se vê e não se sente, por exemplo) que aparece como algo impossível de ser representado. No palco, assistimos à representação materializada da vida virtual que se fortalece por meio imagético e, também, sonoro presentes na encenação.

Segundo Jameson (1995), a pornografia é a prática da violência de maneira simbólica, é a alegoria da imagem pós-moderna, cuja finalidade única é a fascinação, que se oferece como mero prazer ${ }^{134}$. Esse prazer, todavia, nunca se concretiza em $S F$ ou, no máximo, apenas de forma parcial e momentânea. Algo correspondente à prática e à finalidade do consumo em geral. A propaganda e o marketing colocam as mercadorias ao nosso alcance e as definem como sinônimo de felicidade/prazer. Mas, mesmo aos consumidores que as podem comprar, esse prazer é sempre fugaz-logo se esvai. E é isso que mantém o sistema aquecido, gerando sempre novo desejo de consumo e um pouco mais de felicidade, fazendo a roda da economia girar. O sexo "despersonalizado", além de alegoria desse sistema, é na peça, também, exemplo do fracasso de qualquer projeto que não seja individual. Como o consumo, é a expectativa de se alcançar a felicidade sozinho (se eu comprar algo, esse algo me trará felicidade). É a masturbação sem gozo, propiciada por Lulu a Robbie na sala da enfermaria. É o sexo oral pago a Gary em que Mark, após um lapso de prazer, se vê enojado e com o rosto todo manchado de sangue. É um brevíssimo momento entre Gary e Mark em um provador de loja, logo interrompido pela fala sem freio de Gary, relacionando o “tesão" de Mark às compras ${ }^{135}$. E, finalmente,

\footnotetext{
134 “O visual é essencialmente pornográfico” (JAMESON, 1995, p. 1).

135 Cf. RAVENHILL, 2001, p. 54.

Mark: Por que você não espera lá fora? [Why don't you... wait outside?]

Gary: Eu não estou entediado. [I'm not bothered.]

Mark: Vai dar uma volta por aí. Só vou demorar alguns minutos. [Have a look around. I'll only be a few minutes.]

Gary: Agora é tarde. Eu já vi. [Too late now. I've seen it.]

Mark: Viu o ...? [Seen the ...?]

Gary: Vi o pau duro. [Seen the hard-on.]

Mark: Ah sim. O pau duro. [Ah yes. The hard-on.]

Gary: Já deve estar doendo. Duro o dia inteiro. São as compras que fazem isso? Você tem um negócio com compras? Ou isso é por causa de mim? [Must be aching by now. Up all day. Is it the shopping does that? You gotta thing about shopping? Or is it 'cos of me?]
} 
a dor e o prazer efêmero de Gary que, por via sadomasoquista, coloca ponto final em sua vida e, simultaneamente, em sua busca pelo prazer, consumado no aniquilamento.

De modo semelhante ao que ocorre no filme Short Cuts (1993), de Robert Altman, segundo a análise de Solange Grossi (2007), a peça de Ravenhill sai ganhando graças à sua falta de fruição: ela não é esteticamente perfeita segundo as regras do consumo ${ }^{136}$. As imagens de $S F$ (de sexo e violência, já tão assimilados imageticamente por meio da indústria) descem engasgadas, pois pecam pela total falta de atratividade, do glamour próprio a todo produto vendável. Ademais, seus personagens representam o anti-herói de qualquer propaganda de mercadoria. Perdedores [losers] natos, eles são a antítese da imagem de sucesso.

Curiosamente, as políticas públicas de estímulo ao consumo resultam em uma sociedade repleta de perdedores, pois o consumo, como princípio, deve gerar continuamente, em todos os consumidores, a insatisfação incessante e vital à economia; até mesmo entre os mais ricos que "precisam" ter sempre mais. Desse modo, paradoxalmente, as sociedades mais desenvolvidas economicamente são aquelas formadas pelos indivíduos mais ávidos por novidades e, portanto, mais carregados desse sentimento cíclico de "insatisfação".

Em $S F$, assim como nos controversos filmes do diretor Lars von Trier, lançados em 2013, Nymphomaniac Vol. I e Vol. II, o sexo funciona como tentativa de escape frente à incapacidade "de sentir" e de se relacionar com o outro senão de maneira reificada. Nessa receita de independência e reação ao sistema por meio da sexualidade, o tempero acaba azedando em ambos os casos, e o resultado é indigesto: os personagens, ao final,

\footnotetext{
${ }^{136}$ Cf. GROSSI, 2007, p. 76.
} 
sujeitam-se plenamente às forças da circunstância, afundados até o pescoço no receituário da sociedade de consumo.

Além disso, o sexo, mostrado como mercadoria degradada e insatisfatória, culmina na violência física extrema que leva à morte do personagem Gary. No âmbito mais geral, a violência do processo de reificação sistêmica relaciona-se à violência na esfera pessoal, mostrada por meio de sofrimento ou, muitas vezes, apatia, que, narrativamente, leva os personagens a construírem outras estórias e, assim, fugirem daquela realidade.

\subsection{O corpo ausente em Pool (no water)}

Nessa peça, o corpo é emoldurado, assim como influenciado e remodelado, dentro do discurso da arte, a fim de se criar uma imagem esteticamente sofisticada da experiência corporal. Pool apresenta a reificação do corpo por meio da presença desumana da sensibilidade artística. E também documenta a corporeidade rebelde de um indivíduo que, por meio do sofrimento e da lesão corporal, consegue voltar à vida e reconstituir a sua presença de uma forma diferente. A estória contada na peça fala sobre o tema do corpo, corpo este que se torna refém de práticas artísticas.

Ravenhill analisa deliberadamente o significado das sensações corporais e as maneiras possíveis de comunicá-las ao mundo exterior. $\mathrm{O}$ registro do sofrimento da paciente é falso ou real? Essas fotografias representam a dor ou uma exposição estetizante e orquestrada do corpo? Quem é o autor dessas imagens e quem pode ser considerado o artista verdadeiro - é o paciente que se promoveu como material artístico para as fotos ou os personagens que tiveram a ideia de fotografá-la? O modo como os personagens falam sobre essa experiência e verbalizam o interesse voyeurístico enquanto observam aquele 
corpo agonizante pode não indicar alguma resposta para essas perguntas, mas é capaz de expor a complexidade envolvida nessa discussão.

A peça mostra uma visão de artistas cuja única proposta é procurar "um enquadramento", segundo afirmam os próprios personagens, e categorizar o mundo de acordo com princípios estéticos. O julgamento do mundo pelo nível de seu potencial estético leva a uma necessidade obsessiva de vê-lo como um possível trabalho de arte. A vida de um corpo machucado e agonizante atrai atenção não por razões humanísticas, mas porque oferece material para a criação de uma obra artística interessante: "Há um pequeno fluxo de xixi saindo dela agora - verde de tanto vinho. E é o - engraçado pensar sobre isso agora - é o xixi que atrai a nossa atenção"137.

Obviamente, o corpo não poderá falar por si mesmo, e a dor e a lesão física precisam de um tratamento artístico. Por isso, os personagens/fotógrafos reorganizam a cena, oferecem-lhe uma luz adequada, procuram pelas possibilidades mais interessantes de fotografá-la e começam a documentar a recuperação da paciente:

E a luz era boa e o potencial para composição estava todo ali - e para ser honesto isso foi fácil fácil fácil fácil para chegar àquelas imagens que, mais tarde, pareciam marcantes [...]. E a tentação de organizar só mover a cama... então... então a composição estava... coloca a cabeça na luz, então. A tentação era grande, e nós éramos fracos. Então, nós direcionamos a cabeça dela para a luz e, na verdade, movemos os membros e a cabeça - garantindo, é claro, que não desconectaríamos os

\footnotetext{
${ }^{137}$ Op. cit., p. 304.
}

There's a little stream of piss comes out of her now - green from all the wine. And it's the -funny to think of it now - it's the piss that focuses our minds. 
tubos e os medicamentos intravenosos e ... a ciência e a arte podem trabalhar juntas e alegremente. ${ }^{138}$

O que ecoa nessa cena é o seu possível significado e as possibilidades de se expressar ou não uma experiência autêntica. A reorganização daquele evento tinha a finalidade de melhorar a visibilidade, clarear a mensagem, facilitar a visão e a análise dos seus possíveis espectadores. Ou, além disso, Ravenhill poderia também estar propondo uma crítica ao processo que, "na era da reprodutibilidade mecânica", nos termos de Walter Benjamin, aniquila a autenticidade de um objeto, destrói a sua aura, e impossibilita aos espectadores perceberem a sua real presença. Pois, segundo Benjamin (1987, p. 21617), "agora, as massas querem tudo próximo", e tudo aquilo que é produzido adquire uma "qualidade universal" em vez de uma singularidade. Os objetos passaram a ser vistos segundo o "valor de exibição", perdendo o seu valor de "culto" ou "ritual".

A "composição" criada pelos artistas remove o corpo do seu ambiente "natural" e desorganiza os seus rituais ordinários. O corpo não está mais livre para desenvolver os seus movimentos próprios ou desempenhar as funções práticas do dia a dia. $\mathrm{O}$ seu valor de culto está morto, havendo em sua presença apenas o valor de exibição. Em outras palavras, foi-lhe destituída a sua "autonomia", referindo-se novamente a um termo de Benjamin. Essa linha de pensamento continua a ser desenvolvida pelo crítico teatral Philip Auslander e pela sua teoria da "vivacidade", uma tradução possível para o termo inglês liveness. Segundo Auslander, as pessoas atualmente têm experiências de mundo

\footnotetext{
${ }^{138}$ Op. cit., p. 306.

And the light was good and the potential for composition was all there - and to be honest it was easy easy easy easy to come up with those images that so later seemed striking [...]. And the temptation to arrange just to move the bed ... so ... so the composition was ... get her head in the light, so. The temptation was great and we were weak. So we wheel her into light and actually move the limbs and head -checking of course not to disrupt the tubes and drips and...science and art can work together happily.
} 
primeiro por meio de imagens midiatizadas e, somente, assim, podem ou não ter acesso à sua versão original.

Os artistas de Pool parecem perceber o vácuo formado pela representação artística que eles mesmos produzem e consideram como "vida real". E, assim, percebem a necessidade de transgredirem as categorizações estéticas e sentirem compaixão. No entanto, esses sentimentos perdem a batalha contra a vontade insaciável que os cerca de observar, analisar, criar e reivindicar autoria pelo "evento". Todos os personagens de Pool foram infectados pelo vírus da estetização simulada:

E nós queríamos sentir o que ela estava sentindo - ela é uma de nós, nós somos artistas - não, nós somos pessoas - nós queríamos sentir o que ela estava sentindo - compartilhar a dor. Mas isso não aconteceu. Nós ficamos ali. Nós ficamos ali e assistimos às contrações, e nós ouvimos os gritos. E ficamos ali assistindo. Todos nós. ${ }^{139}$

O que transparece na cena, assim como em muitas outras, é o estado de apatia ou indiferença presente. A dor sofrida pela artista lesionada não se traduz na compaixão humana dos seus amigos mas em uma possibilidade de representar aquela situação artisticamente. Pool irradia ceticismo quanto à possibilidade de o corpo ser um meio privilegiado de expressão. Não se trata de um meio perfeito de "expressão para as dimensões emocionais, libidinais e primitivas da experiência humana" e sequer livre das “expressões verbais (intelectuais)", que permitiria ao inconsciente ou ao intuitivo se sobressair ${ }^{140}$.

\footnotetext{
${ }^{139}$ And we wanted to feel what she was feeling - she is one of us, we are artists - no, we're people -we wanted to feel what she was feeling -share the pain. But it didn't happen. We stood. We stood and we watched the jerking and we heard the screams. And we stood and we watched. All of us (p. 302).

${ }^{140}$ Citação de FOSTER em AUSLANDER, 1999, p.73.
} 
De acordo com Maurice Merleau-Ponty (1962, p. 153), o corpo é um intermediário do nosso conhecimento ou pertencimento ao mundo. É o responsável por criar sentido, conforme "o processo de entender os significados [que] é desempenhado pelo corpo". As peças de Ravenhill identificam a lenta deterioração da capacidade do nosso corpo de estabelecer e manter contato com o mundo exterior.

Essa peça, assim como $S F$, parece sugerir que o corpo é o elemento mais vulnerável no mecanismo comunicativo ou na expressão do sistema econômico. Essa deve ser uma das razões pelas quais as fotos da famosa fotógrafa norte-americana Nan Goldin despertaram a imaginação desse dramaturgo. Os livros/álbuns contendo fotos "íntimas de amigos boêmios, sob efeito de drogas, multissexuais, doentes e feridos" sugerem a ideia do corpo como artefato, da carne humana transformada em mero material feito para inserção de brincos, piercings, tatuagens e perfurações ${ }^{141}$.

Segundo Ravenhill, "amizade, doença e a transformação da sua vida numa estória ou em fragmento artístico - esses eram os pontos que sobressaiam das fotos" ${ }^{\text {142 }}$. Todos os corpos em Pool estão igualmente presos pela reprodução mecânica de significados, pela repetição de uma rotina familiar. Expressões emocionais explosivas ressoam apenas quando são provocadas por estímulos baratos, afetados e descartáveis. A percepção de contato entre os personagens chega à superfície somente quando está canalizada por meio de uma experiência coletiva, quando as emoções deles estão expressas no mesmo diálogo. Não há individualidade e nenhuma possibilidade de comunicação fora da linguagem banal e ordinária.

A produção original realizada pela Frantic Assembly no ano de 2006 realça mais visivelmente dois aspectos do texto: o extravasamento emocional que os atores

\footnotetext{
${ }^{141}$ RAVENHILL, 2006, em entrevista.

${ }^{142}$ Op. cit., 2006.
} 
desenvolvem performática e coletivamente, assim como o caráter repetitivo dos movimentos $^{143}$. O cenário une o quarto de um hospital com o fundo azulejado de uma piscina. Os atores usam todo o espaço, inclusive as paredes, que são escaladas em alguns momentos por meio de cabos, suspensos e presos ao teto. O texto de Ravenhill é proferido em constante movimentação, entre caminhadas, corridas e pulos. A performance é repleta de fisicalidade que, em certos momentos, assume uma forma de dança, e, em outros, sucumbe sob um peso invisível ou uma força inumana, levando o corpo dos atores ao limite da contorção e do espasmo.

O movimento ordenado e sincrônico de todos os corpos no palco cria um efeito de sofrimento, terror, êxtase ou medo. O espetáculo parte de "ações físicas num ritmo regular", nos termos de Sarrazac (2017, p. 320), assim como de falas corriqueiras, até chegar a um ápice de movimentos sequencias carregados de emoções intensas e certa afetação.

O texto é enunciado com certa artificialidade, vogais estendidas e palavras gritadas, e dirigido por uma necessidade de mudar a composição textual monológica em uma erupção dialógica do subconsciente, uma sensibilidade, até certo ponto, desarticulada. O corpo lesionado ocupa uma posição central durante a maior parte da performance. É sobre esse corpo e com esse corpo que os personagens falam constantemente. Os atores que se revezam posicionados na cama do hospital não respondem e nem se movem.

A invisibilidade perturbadora da presença humana transforma o corpo silencioso em um recipiente vazio que pode ser preenchido com tudo aquilo que os outros

\footnotetext{
${ }^{143} \mathrm{O}$ vídeo dessa montagem de Pool só está disponível, nas salas de estudo da Biblioteca Britânica, em Londres. Em http://cadensa.bl.uk/uhtbin/cgisirsi/?ps=s0s79oe7TN/WORKS-FILE/158650043/9. Acesso em 15 de janeiro de 2019.
} 
personagens queiram. Em uma das longas sequências sem falas, os personagens começam a fazer mímicas de uma discussão com o corpo inconsciente da amiga. A cena evolui para uma explosão de raiva e criticismo na qual o corpo sem movimento é repreendido, xingado e atacado fisicamente. A agressão logo se transforma em abuso sexual e, quando um dos personagens encena sexo anal com o paciente vegetativo, torna-se evidente que aquele corpo sem movimento desperta os piores e mais recônditos estímulos projetados em todos os membros do grupo.

\subsection{Considerações sobre a montagem do Frantic Assembly}

Durante a nossa estada na Inglaterra, como pesquisador visitante, na Universidade de Surrey, em janeiro de 2019, tivemos a oportunidade de assistir ao vídeo da montagem original da peça Pool, disponível na Biblioteca Britânica de Londres ${ }^{144}$. O espetáculo produzido pela companhia Frantic Assembly mostra a cultura e a moralidade como uma fina camada superficial encobrindo uma outra, problemática e embrutecida. A consciência ausente desse corpo sem movimento garante a impunidade dos demais. E a passividade indefesa estimula os outros corpos a extravasarem os seus desejos. O corpo no palco, embora fisicamente visível, permanece quase ausente - destituído de

\footnotetext{
${ }^{144}$ A Biblioteca Britânica [British Library] é a Biblioteca Nacional do Reino Unido, uma das maiores do mundo. Atualmente, o seu acervo possui aproximadamente 150 milhões de itens e a cada ano incorporamse à coleção cerca de três milhões de itens novos. Durante os nossos estudos naquele país, também tivemos acesso ao acervo de pesquisa físico e eletrônico disponível para os alunos de pós-graduação da Universidade de Surrey [Surrey University], onde, por ação do professor Bran Nicol, Chefe do Departamento de Língua e Literatura Inglesas, reunimo-nos com pesquisadores e professores, debatendo as nossas pesquisas. Graças ao convite da professora Ana Cláudia Suriani da Silva, responsável pela disciplina Estudos Brasileiros [Brazilian Studies], na Universidade College London [University College London], participarmos de uma aula de Língua Portuguesa e Literatura Brasileira apresentando apontamentos sobre a nossa pesquisa num interessante debate intercultural com os colegas ingleses. Ao longo desse período de estudos em Londres, assistimos não só a peça mais recente de Mark Ravenhill, como também a diversas peças de dramaturgos contemporâneos ingleses, muitas delas recomendadas pela Professora Ida Sedler, de Teatro e Performance, da Universidade de Londres - Birkbeck [Birkbeck, London College], a quem somos muito gratos pela troca contínua de ideias.
} 
consciência e julgamento moral, ele se metamorfoseia em um misto de objeto inanimado e bode expiatório inadvertidamente assumindo a responsabilidade por todas as mazelas que os outros personagens acreditam sofrer.

O fato de Ravenhill não especificar quem são os personagens determinados para cada fala, e a possiblidade de se identificar uma variedade de falantes, dependendo do modo como lemos o texto, cria uma gama de possibilidades no que diz respeito ao desenvolvimento de formas e significados atribuídos à produção dessa peça. Esse tipo de composição projeta uma ideia de certa "singularidade" ao texto, no termo empregado por Derek Attridge (2004).

O texto soa mais como uma expressão original de emoções em vez de, simplesmente, como uma reprodução artificial de um cenário inventado. Há um modo pelo qual o texto literário pode existir como um "evento", referindo-se novamente a Attridge (2004, p. 55-62). O texto deixa mais espaço para os atores preenchê-lo livremente com seus sentimentos. O teatro de Ravenhill ao usar intensamente repetições, hesitações ou expressões que possam ser consideradas emocionais força os atores a uma postura, uma atitude física.

Frases como, “aqui vamos nós aqui aqui vamos nós a -a-a-a-a-a-a - aqui va-a-avamoooos nóóóóssss!"145, ou "nós sequer sabemos quem acondicionou primeiro a câmera digi-digi-digi-digital"146 e "agora ela tem: a piscina. A pisciiiiinaaaaaa"147 perdem o valor informativo próprio do discurso e funcionam emocionalmente mais como condutores de tensão, estresse ou excitação. Ainda assim, a codificação gráfica desses sentimentos não

\footnotetext{
145 Op. cit., p.321.

Here we go here here we go here $h-h-h-h-h-h-h$-here weeee g-g - g-gooooo!

${ }^{146}$ Op. cit., p.305.

We don't even know who first packed the digi-digi-digi-digi-cam

${ }^{147}$ Op. cit., p. 206.

And now she has: the pool. The poooooooooool
} 
determina a intenção dos personagens. É a direção e a reação do ator à situação que determinará a forma que o som dessas palavras pode assumir. O modo como os atores comunicam as palavras e a maneira como os sentimentos são expressos não coincidem, havendo sempre um descompasso ou, então, um desvio da norma entre esses dois meios de expressão. Quando falam sobre "selecionar" e "deletar" as fotografias, tiradas da amiga, durante o período dela de internação, os personagens expressam algo muito além de apenas apagar imagens ${ }^{148}$ :

E, em seguida, uma grande onda de diversão

Selecionar Deletar Selecionar Deletar Selecionar Deletar Selecionar

Deletar Selecionar Deletar Selecionar Deletar Selecionar Deletar

Selecionar Deletar Selecionar Deletar Selecionar Deletar Selecionar

Deletar Selecionar Deletar Selecionar Deletar Selecionar Deletar

Selecionar Deletar Selecionar Deletar Selecionar Deletar Selecionar

Deletar Selecionar Deletar Selecionar Deletar Selecionar Deletar

Selecionar Deletar Selecionar Deletar Selecionar Deletar Selecionar

Deletar Selecionar Deletar Selecionar Deletar Selecionar Deletar

Selecionar Deletar Selecionar Deletar Selecionar Deletar Selecionar

Deletar Selecionar Deletar Selecionar Deletar Selecionar Deletar.

A peça torna-se um exemplo de como o papel do texto no teatro contemporâneo pode ser redefinido. O texto é menos formal, menos estruturado e aberto a uma variedade

${ }^{148}$ And then a great wave of fun

Select Delete Select Delete Select Delete Select Delete Select Delete Select Delete Select Delete Select Delete Select Delete Select Delete Select Delete Select Delete Select Delete Select Delete Select Delete Select Delete Select Delete Select Delete Select Delete Select Delete Select Delete Select Delete Select Delete Select Delete Select Delete Select Delete Select Delete Select Delete

Select Delete Select Delete Select Delete Select Delete [...](RAVENHILL, p. 320, 2006). 
de leituras, sugerindo espaços em branco e convidando os atores a introduzirem as suas intervenções imediatas. Ainda assim, um texto desse tipo tem um papel gerador na produção do espetáculo. Ele propicia a possibilidade de o significado se incorporar. Esse esquema evita um selamento das possibilidades interpretativas que poderia transformar a representação em algo completamente fictício. Sequências improvisadas de teatro físico ${ }^{149}$, centrado na experiência corpórea dos atores e, por conseguinte, também do público, e uso de linguagem que lembra a de máquinas buscam uma suspensão do teatro do tipo "pacto ficcional" e acabam causando um efeito angustiante. A encenação de Pool depende da experiência viva, intensa e convulsiva dos atores a fim de recusar qualquer espécie de ilusionismo. Assim, o corpo da amiga lesionada encontra o seu próprio modo de reconquistar o palco e se apresentar como um princípio controlador.

\subsection{O aniquilamento do corpo}

Em $S F$, a única aparição "real” de marca de sangue surge na cena final, em que Gary, num jogo narrativo, fala sobre seu desejo de ter alguém que se preocupe com ele e, em seguida, do desejo de ser violentado pelo pai. E, então, Robbie o penetra com uma chave de fenda. Essa vontade de servir como objeto de desejo do outro é, nesse caso, também, um desejo de morte, como se o pensamento de ser importante ou desejado fosse capaz de causar a solidão, a depressão e, então, o aniquilamento.

Por sua vez, as fotos de Pool, retratando a enfermidade e o corpo ferido, entre outras figuras de violência, apresentadas como tentativas de conexão por meio de atos perversos, podem ser vistas como ações desesperadas da afirmação de um instinto egoísta,

\footnotetext{
${ }^{149}$ Trata-se, segundo Sarrazac (2007, p. 314) da parte física preponderante que não pode ser fixada e escrita "na linguagem habitual das palavras; e que mesmo essa parte escrita e falada o será num sentido novo".
} 
ganancioso e individualista. Os atos de crueldade dos personagens $\mathrm{A}, \mathrm{B}, \mathrm{C}$ e D frequentemente acompanham atos de carinho, em cenas carregadas de ironia e contradição.

Em $S F$, Mark, Robbie e Lulu terminam a peça juntos e "felizes"; e os amigos de Pool reforçam os seus "laços de amizade" ao longo do enredo; em cada caso, uma espécie de fantasma representando um mundo melhor, um modo melhor de estar com os outros e que, pela condição degradante, poderia ser capaz de assombrar o estado de violência permanente. 


\section{4. "O valor é o homem"150}

Gênero é uma categoria tão integrada ao nosso dia a dia que estende o seu domínio para quase todas as lutas e conflitos sociais. Segundo Judith Butler (1990, p.6), o gênero aparece como "artifício fluido", algo que, como "um fenômeno contextual e cambiante, não denota um estado substancial, mas um ponto relativo de convergência entre relações culturais e historicamente específicas". Por se tratar de uma construção social, o gênero não poder ser inato. A categoria de gênero extrapola a de sexo. O estereótipo de gênero opera como outras divisões binárias: masculino/feminino, público/privado, ativo/passivo, forte/fraco, dominante/submisso, ordem/desordem, racional/emocional, líder/seguidor, indivíduo/massa. A partir dessas relações, um homem que exerce um trabalho manual, por exemplo, pode ser considerado "feminizado" por causa da sua relativa impotência ou falta de autoridade. Além disso, o discurso retórico também é capaz de associar explicitamente "as massas" ou o efeito de massificação com aquilo que é da ordem do feminino. Segundo Andreas Huyssen (1986), Nietzche, por exemplo, teria descrito as massas como assumindo um comportamento "histérico", termo esse derivado da palavra grega uterus $^{151}$.

Compreender a relação entre os personagens representantes dos gêneros masculino e feminino é, de certo modo, analisar as relações entre o sistema econômico e o patriarcado, entre a formação social onde predomina a produção do valor e a violenta sujeição que os homens impõem às mulheres. Verificamos, assim, diversas formas de expressão da dominação masculina nas sociedades contemporâneas.

\footnotetext{
${ }^{150} \mathrm{O}$ título e a análise desse capítulo são influenciados pelo ensaio escrito pela pedagoga e ativista alemã Roswhita Scholz, intitulado O valor é o homem, escrito em 2017, e procuram dialogar com ele.

${ }^{151}$ As cisões entre feminino e masculino são comprovadas até mesmo nas mais abstratas concepções teóricas da antiga filosofia. Para Platão, por exemplo, a matéria é algo amorfo e dificilmente apreensível pelo pensamento, sendo definida (com gênero feminino) como a "hospedeira e a ama das ideias". Também para Aristóteles o amorfo como byle (traduzido em latim por Cícero como materia, de onde vem a designação corrente entre nós) é um conceito feminino (cf. PAULI, 1990, p.197).
} 
Se se entende que esse patriarcado está relacionado com um tipo específico de atividade social, que tem na realização do valor o seu fundamento, a superação da dominação de gênero exige que se vá além exatamente desse modo de sociabilidade vinculada à produção de mercadorias, à produção de valor ${ }^{152}$.

\subsection{O feminino em Shopping and Fucking}

O título explícito de $S F$ e o retrato brutal de sexo violento na peça receberam mais comentários do que o uso de imagens de televisão e filmes apresentados nas encenações e discutidos pelos personagens ao longo do roteiro. Ao comentar sobre $S F$, o crítico Alastair Macaulay (1997), do jornal inglês Financial Times, afirmou que SF, além de ser a peça mais chocante a chegar aos principais palcos londrinos, não poderia ser analisada como uma peça, pois se parecia mais com "um desenho animado inteligente, sensacionalista e perturbador". Em certo sentido, a afirmação reforça a ideia de uma linha divisória entre uma arte mais elitista e outra mais massificada. Uma peça, nessa perspectiva, existiria em distinção a formas artísticas mais populares, como os desenhos animados. Negar a $S F$ a identidade de peça demonstra a sua natureza híbrida e capaz de se impregnar de um tom e uma sensibilidade estética que lembra a de um desenho

\footnotetext{
152 Nas palavras da feminista alemã Roswhita Scholz (p. 18, 2017):

A fim de enfrentar a crise de modo produtivo, há que se constituir uma 'esquerda feminista' que tenha consciência tanto subjetiva e pessoal quanto objetiva e social do mecanismo de cisão [entre os gêneros]. Um feminismo nesses moldes não se pode dar ao luxo de restringir-se às mulheres e ao movimento feminista. Tanto homens quanto mulheres têm de compreender que 'nossa' sociedade é determinada pelo patriarcado e pelo valor. [...] além disso, é urgente a luta feminista de ambos os sexos contra as formas de existência sociais, objetivadas e reificadas das cisões patriarcais produzidas pelo valor. A superação do patriarcado é ao mesmo tempo a superação da forma fetichista da mercadoria, pois esta é o fundamento da cisão patriarcal. O objetivo revolucionário seria, portanto, um grau mais elevado de civilização, no qual homens e mulheres sejam capazes de fazer pelas próprias mãos sua história, para além do fetichismo e de suas atribuições sexuais.
} 
animado, usando as influências de certos filmes populares e do aparelho de televisão como elemento figurativo no palco a fim de se criar uma fisicalidade teatral incomum ${ }^{153}$.

O personagem Brian, que faz o papel de um pequeno traficante, sem nomear explicitamente o filme da Disney, $O$ Rei Leão, cita-o, na cena 2, algumas vezes a fim de justificar as suas ações e indiretamente elucidar a interferência de outras mídias nessa peça. No filme, um trio de hienas simboliza "as massas criminosas", alinhando-as a um perfil estereotipado feminino. Falando e emitindo sons em alto volume, as hienas representam uma emoção descontrolada: são imaturas, autocentradas e amorais. Histéricas e afeminadas, fracas e inúteis, representam a passividade feminina, o oposto da ação e liderança majestosas.

Além disso, a convivência em grupo das hienas contrasta com a individualidade resoluta e masculina, primeiro, do Rei Mustafa e, então, do seu filho, Simba. Ravenhill associa o trio (dos socialmente excluídos) Lulu, Mark e Robbie, em $S F$, às hienas histéricas do filme da Disney ${ }^{154}$. Como os seus equivalentes do desenho animado, o trio de Ravenhill irrompe em emoções inapropriadas, rindo descontroladamente e agindo sob impulso, além de se sujeitarem à autoridade masculina, representada na peça pelo personagem traficante que não se poupa em aproximar a sua relação de pai e filho com a existente entre o Rei Mustafa e o pequeno Simba: "o filho cresceu. E você sabe - ele se parece com o pai”155. Quando o trio perde o dinheiro devido a Brian, este personagem

\footnotetext{
153 À época de estreia $S F$, Ravenhill também escrevia roteiros para uma série de televisão britânica bastante conhecida na Inglaterra, intitulada This Life.

${ }^{154} \mathrm{Ver}$ https://www.youtube.com/results? search query=simba+hienas. Acesso em 12/03/2019

${ }^{155}$ No início da cena 2, o personagem Brian ao entrevistar Lulu faz a sua primeira citação do filme (p.8), "e aí chega essa cena. Essa cena que é realmente demais. Provavelmente a melhor cena. Porque olha, você pode imaginar, o pai dele morto. O Rei Leão foi esmagado por uma boiada gigante e selvagem. Você transbordaria de tristeza".

And there is this moment. This really terrific moment. Quite possibly the best moment. Because really, you see, his father is dead. Yes? The Lion King was crushed - you feel the sorrow welling up in you-crushed by a wild herd of these big cows (na versão original).
} 
lhes explica a punição por meio de alusões ao filme, referência esta que Lulu imediatamente reconhece ${ }^{156}$.

A peça usa o filme e a televisão a fim de reforçar a associação do feminino com a desordem e o caos. Como sugere o título, shopping é parte da desordem causada pela cultura de massas, e o desejo de comprar é produzido por uma cultura do consumismo exemplificada pelo aparelho de televisão que aparece centralizado sobre o palco na montagem original da peça.

Em controversa afirmação, Robin Roberts (2001, p. 121), professor de artes cênicas, da Universidade Franklin College, nos EUA, defende que "a primeira palavra do título, 'shopping', evoca o gênero feminino", pois, "desde a sua inserção no final do século XIX, o consumismo moderno tem sido associado e direcionado às mulheres"157. Já Ravenhill representa as compras como um fraco substituto para a tomada de ações e o exercício de autoconhecimento. Ao suscitar o gênero feminino por meio da condenação da palavra "comprar", a peça usa a televisão e o filme da Disney como um sinal da depravação e incapacidade daqueles três personagens.

Ao se concentrar nos modos como as compras e o sexo são usados como válvulas de escape de um certo sentimento de angústia dos personagens, a montagem de estreia atribui ao aparelho televisor a capacidade de definir e moldar muitas das ações. O desejo de "comprar" [shopping] e "foder" [fucking] são estimulados, simulados e comentados conforme os personagens assistem à TV. O aparelho, posicionado como um participante do elenco, atrai a atenção de todos, inclusive a dos espectadores.

\footnotetext{
${ }^{156}$ Ver cena 2 para mais momentos de citações do filme e que continuam durante outras cenas embora de maneira mais indireta.

157 "The first word in the title, "shopping," evokes the feminine. From its inception in the late nineteenth century, modern consumerism has been associated with and directed toward women" (ROBERTS, 2001, p. 121).
} 
As encenações de $S F$ costumam destacar o modo como a televisão nos isola. Em alguns momentos, Lulu e o personagem traficante interagem com a televisão em vez de olharem ou abordarem um ao outro diretamente. E, na cena 5, quando Lulu diz a Robbie ter observado, por meio de uma câmera de monitoramento, ligada a uma TV, o assalto e o espancamento da atendente e caixa de uma loja de conveniência, ela se sente mal por ter sido incapaz de intervir ou chamar uma ambulância.

Nesse caso, a mediação televisiva distancia Lulu daquele ato de violência ao passo que sua atenção é atraída por esse meio. $\mathrm{O}$ fato de Lulu ser a única personagem feminina da peça que assiste à violência midiatizada, incapaz de agir, apenas reforça a passividade e a feminilidade de um espectador abstrato. Ao final, vale dizer, são femininos todos os personagens que, fracos e passivos, não têm dinheiro. Sierz (1997) descreve a peça como sendo sobre "uma crise da masculinidade". Então, se o centro da peça é a masculinidade, isto é algo que se mede a partir da feminilidade da cultura popular.

\subsection{O masculino em Pool (no water)}

No jogo de antagonismo entre, de um lado, os personagens A, B, C e D e, do outro, a personagem ausente, estabelece-se a cisão dos gêneros feminino e masculino nessa peça, que pode ser dividida em três grandes momentos: no primeiro, os personagens presentes se encontram distantes da personagem ausente; no segundo, ocorre uma aproximação espacial e física entre eles, com uma breve inversão de papeis ao final desse estágio; e, no terceiro, há um novo distanciamento entre os personagens e a amiga famosa. Contraditoriamente, a peça mostra a exclusão do feminino por meio da sua presença no placo, e o domínio do masculino pela sua ausência, que está ligada a um mundo fictício, irreal ou, no mínimo, voltado para o passado. 
Num primeiro momento, após certa hesitação, o grupo decide visitar a amiga famosa. A distância entre eles é muito grande assim como a mágoa que guardam dela. Para chegar até a casa da amiga, descrita como um “oásis distante”, é preciso ir de avião. Ela viveria praticamente sozinha se não fosse pela presença de dois funcionários: o limpador de piscina e o personal trainer. Sua agenda é agitada, voltada para o trabalho, está sempre viajando, fazendo exposições, vernissages. Os demais personagens, por sua vez, mantiveram a amizade e o contato entre si; e envelheceram. A limitação financeira é algo comum entre o grupo de amigos que parecem entediados com a vida que levam.

Num segundo estágio, quando chegam à casa da amiga, há um conflito inicial entre esses dois lados, marcado por uma certa soberba da amiga anfitriã que, a fim de aparar as arestas e diminuir a distância entre eles, logo promove uma festa ao lado da piscina. Desregrados, a anfitriã e os convidados bebem, divertem-se e, assim, aproximamse até o ponto no qual não há mais distinção entre personagens ausentes e presentes: “o grupo está unido novamente”. Cada vez mais, todos parecem ser um só. A anfitriã, então, mergulha de encontro ao fundo vazio da piscina e é levada às pressas para o hospital. E, então, tem início um processo momentâneo de fusão entre esses dois polos marcado pela atuação dos personagens.

Apoiados pela encenação, vemos os personagens alternando-se no papel da personagem acamada. 


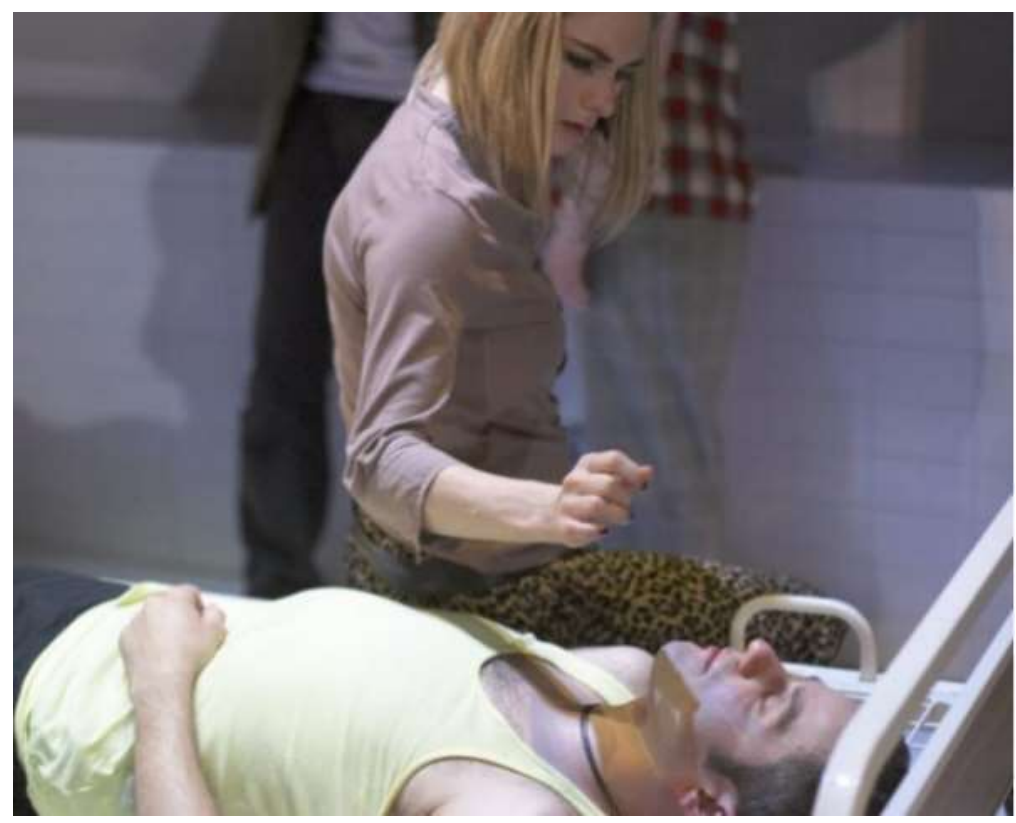

A imagem mostra $o$ ator no papel da personagem ausente. Disponível em https://www.franticassembly.co.uk/productions/pool-no-water\#resources. Acesso em 12 de dezembro, 2019.

Nesse momento, a ausência da personagem ganha certa corporeidade, deixando o plano apenas das descrições narrativas e transformando-se em presença por meio dos demais, presença esta de caráter feminino, pois a condição geral de impotência se realça no momento em que ela se torna dependente dos personagens A, B, C e D. Inconsciente e fisicamente incapaz de se mover, os amigos passam a fotografá-la, posicionando e moldando o seu corpo como se manipulassem um fantoche.

Voltados para um corpo inerte, os personagens desferem palavrões e ofensas, de certo modo, a si mesmos, pois são eles próprios deitados no leito. E, conforme a ação cresce em intensidade, estupram-na na calada da noite.

Em meio a isso, ocorre o registro fotográfico do processo de recuperação da amiga. E, assim, os personagens acreditam estar fazendo arte, "somos artistas", afirma um deles, enquanto aproveitam também para frequentar a casa e a piscina da personagem ausente. Nesse momento, os papeis parecem se inverter por um breve período. A 
personagem ausente assume, sozinha, a condição do gênero feminino enquanto os demais migram para o masculino, pois se empoderam da casa e da vida que leva a anfitriã.

No entanto, a ação do grupo de vivenciar a vida da personagem, agindo como se fosse ela, assim como fotografando-a no hospital, não passa de uma imitação tanto do estilo de vida quanto do próprio método criativo da personagem enferma que, conforme se recupera, passa a se interessar pelo que os amigos estão fazendo. Empreendedora, ela tem a ideia de promover as fotos, realizar uma exposição e vendê-las, ideia esta que causa indignação ao grupo. Eles, então, destroem as fotos, "selecionar, deletar, selecionar, deletar, selecionar, deletar"158, diz o texto sobre a ação dos personagens. A intenção deles era agredi-la e, não, motivá-la profissionalmente.

Conforme a sua estadia no hospital aproxima-se do fim e outras pessoas passam a visitá-la, o grupo reconhece, "nós somos empregados domésticos realmente e qualquer dia a partir de agora seremos mandados para casa" ${ }^{\text {159. }}$. Quando ela descobre que o acervo foi eliminado, esbraveja, "vocês são pessoas pequenas"160, segundo um dos personagens. Desse modo, desaparece aos poucos a sua presença física que se volta, novamente, apenas ao plano dos diálogos, como personagem principal da narrativa verbalizada por $\mathrm{A}, \mathrm{B}, \mathrm{C}$ e D.

Ainda segundo a narrativa, o grupo não só apagou todas as fotos, como, também, queimou o disco rígido do computador numa fogueira. A personagem quase recuperada do acidente, então, teria concluído: "há pessoas pequenas e pessoas grandes. E eu sou uma pessoa grande, e vocês não são" ${ }^{\text {161 }}$. E os personagens reconhecem cada vez mais a cisão entre eles e ela: "eu encontrei alguém de que gosto e tenho dois filhos - um tem

\footnotetext{
${ }^{158}$ Select, delete, selec, delete [... ]. (p.321)

${ }^{159}$ And we are housemaids really and any day now we'll be deported home. (p. 317)

160 You are small people. (p. 322)

${ }^{161}$ There are small people and there are big people. And I am a big person and you are not. (p. 322)
} 
dois, e o outro, quatro -, e eles gostam de mim o que me faz sentir bem melhor" ${ }^{162}$. Essa fala serve não só para resumir os finais de A, B, C e D mas, também, para selar a peça.

Como defende Roswhita Scholz ${ }^{163}$, a sexualidade, “a dimensão sensível”, a emotividade, assim como a administração do lar, a educação dos filhos, "o convívio social" e a família são delegados ao polo feminino; enquanto que "o trabalho abstrato", a arte, a fama e o protagonismo são da ordem do masculino. O vai e vem de Pool reforça, ao final, a diferença entre os dois polos.

Diante disso, podemos entender que os personagens presentes em ambas as peças se associam sem exceção a esse polo feminino. Em $S F$, apesar de deter algum recurso financeiro (mínimo), o personagem Brian está subordinado às mesmas regras dos demais em um universo consumista cujas figuras simbólicas, como a "paterna" ou do "homem gordo" 164 , representam, em oposição aos demais, os verdadeiros detentores do capital. Em Pool, esse polo masculino, imbatível e poderoso, é representado pela personagem ausente enquanto os demais são a personificação do lado feminino: frágil, inseguro e empobrecido.

Em um desdobramento dessa discussão: em $S F$, o relacionamento triangular envolvendo os personagens Robbie, Mark e Gary também suscita discussões ligadas à esfera da sexualidade e do gênero e aos seus desdobramentos quanto às diferenças formais presentes na configuração dos personagens na primeira e segunda obras.

\footnotetext{
${ }^{162}$ I actually met someone who I rather like and I have two children - one is two, the other is four - they like me so that makes it feel rather better. (p. 323)

163 "As cisões de que resultam a esfera feminina, o contexto de vida feminino e o âmbito de atividades imputado às mulheres (administração do lar, educação dos filhos, "convívio social", etc.) são portanto elementos integrantes, por um lado, da socialização pelo valor, mas por outro, lhe são também exteriores" (SCHOLZ, 2017, p. 3).

${ }^{164}$ Apenas a título de retomada da discussão, "o homem gordo" integra, entre outras, a narrativa/estória que inicia a peça quando Robbie e Lulu são vendidos por essa figura simbólica a Mark. Por sua vez, "a figura paterna" é tema de análise do subcapítulo de mesmo nome e aparece em diversos momentos do enredo.
} 


\subsection{Sexualidade e mercantilização}

"As pessoas gays já tiveram imagens positivas suficientes [de si mesmas]", disse Ravenhill durante uma entrevista que marcava a estreia de $S F$ em Nova York. "O que aqueles afeminados precisam é de algumas imagens negativas capazes de chacoalhálos"165, afirmou ironicamente o dramaturgo que, diversas vezes já declarou ser soropositivo e ter contraído o vírus de um antigo namorado, morto no decurso da mesma doença $^{166}$. A defesa do dramaturgo de uma perspectiva "pós-gay" é inseparável de uma análise materialista e crítica da contemporaneidade e capaz de revelar uma preocupação com os modos nos quais a História da homossexualidade tem sido teorizada -, mais especificamente, com os modos pelos quais as teorias voltadas para essa questão histórica têm sido levadas a cabo - nas últimas décadas.

Ravenhill defende, na declaração acima, assim como em $S F$, haver um sentimento de alienação condicionado à palavra "gay" e determinado pelo seu significado histórico. A oposição às políticas públicas voltadas para as identidades sexuais parece ser uma outra bandeira defendida pelo dramaturgo. Essa peça - a mais estudada pela academia - segue sendo importante a fim de entendermos questões que envolvam uma visão social e simbólica do universo "gay".

Na introdução do primeiro volume da editora Methuen, Rebellato (2001, p. xv) avalia $S F$ em seu confronto com a teoria pós-moderna defendida por Françoise Lyotard e

\footnotetext{
165 HERMAN, J. New York Entertainment, January 26, 1998. Esse artigo pode ser encontrado em http://nymag.com/nymetro/arts/features/2160/

166 "Com essa narrativa fui presenteado em 1990 quando, aos 24 anos de idade, fui diagnosticado soropositivo. Olhando para trás, eu percebi que era a terrível linearidade dessa narrativa que me levou a escrever peças teatrais e que deu o maior impulso à minha primeira obra: Shopping and Fucking", afirmou Ravenhill em seu artigo publicado no jornal londrino The Guardian e intitulado My near death period [Meu período próximo da morte, na tradução literal]. (Disponível em https://www.theguardian.com/stage/2008/mar/26/theatre, acesso em 26 de fev. 2019.)
} 
"a [sua] incredulidade diante das metanarrativas". Ambientada num contexto fragmentado, $S F$, na interpretação de Rebellato, aceita uma mudança em termos da nossa participação como membros de uma sociedade comum para uma outra em que nos tornamos consumidores ensimesmados de porções de estórias individualizadas ${ }^{167}$.

Mas a suposição que domina uma sociedade desse tipo em que os consumidores são indivíduos autônomos capazes de tomar decisões racionais são minadas por um destaque atribuído a temas como o desamparo e o vício dos personagens. A figura, talvez, mais centralizadora da peça, a do personagem Mark, por exemplo, somente pode conceber a própria independência em termos de uma fala irônica de quem recebe conselhos de um "terapeuta":

Escuta. Quero que você entenda. Eu tenho esse tipo de personalidade, entende? Uma parte de mim é completamente dependente. Eu tenho uma tendência em me definir puramente em termos do meu relacionamento com as pessoas. Não consigo me definir estando sozinho $^{168}$ (RAVENHIIL, 2000, p. 32).

E, em uma cena que ajudou a atribuir à peça "as credenciais de In-yer-face", ele faz a sua oferta de autonomia fazendo sexo oral no michê Gary, ato este que simbolicamente não demanda reciprocidade, mas que, também, por meio do seu fetichismo aparente, expõe a continuidade da dependência retratada como abjeta de Mark em relação aos outros personagens.

\footnotetext{
167 Segundo a análise de David Harvey (1990, p. 141-197), a "condição pós-moderna”, em termos é o resultado de um regime intensificado de acumulação capitalista. (Em The Condition of Postmodernity. Malden and Oxford: Blackwell, 1990). Possivelmente, Ravenhill estivesse familiarizado com o trabalho desse teórico, em virtude das leituras do dramaturgo sobre pós-modernidade e globalização, feitas para a produção da peça Some Explicit Polaroids, encenada pela primeira vez em 1999, na cidade de Londres. ${ }^{168}$ Listen. I want you to understand because. I have this personality you see? Part of me that gets addicted. I have a tendency to define myself purely in terms of my relationship to others. I have no definition of myself you see.
} 
O limite até o qual o sexo se tornou uma transação financeira é sugerido no título da peça, e o seu ceticismo diante de qualquer convicção de que a sexualidade é uma força libertadora é condicionado à relação estabelecida entre "comprar" [shopping] e "foder" [fucking]. Quando Mark termina de fazer sexo oral em Gary, a sua boca está coberta de sangue, o que teria decorrido das feridas não cicatrizadas e dos machucados já adquiridos por Gary, durante um ato violento, em que fantasiava ser abusado por uma "figura paterna”. Essa fantasia, da qual Mark mais tarde participará, simboliza o ápice da crescente e cambiante relação, financeiramente mediada, de dependência entre eles ${ }^{169}$.

Mark, no início da peça, ao falar sobre a necessidade de se tornar independente, expõe a superficialidade própria de uma existência que se mercantilizou. Tal discurso, ironicamente, solapa os anseios não só dele mas de todos os personagens que buscam, por meio de suas narrativas, demonstrarem certo grau de autenticidade. Essas falas revelam uma subjetividade esvaziada pelo senso comum e tornaram-se uma marca da escrita e do tipo de personagens criados por Ravenhill ao longo da sua obra. Por isso, o nosso ceticismo em relação a apontamentos, por exemplo, como os de Caridad Svich (2003, p. 82), que identifica nas falas "ingênuas" dos personagens evidências de uma sentimentalidade de tipo aburguesada e capaz de reverberar por toda a peça.

Svich cita a fala de Robbie, "Foda-se o dinheiro. Fodam-se as vendas. Fodam-se as compras, e vamos ser... bonitos. Bonitos. E felizes" ${ }^{170}$, como uma evidência disso, mas essas linhas são mais um atestado da banalidade e da vagueza das aspirações do

\footnotetext{
${ }^{169}$ Estranhamente, Ravenhill defende que "Gary é assassinado por penetração anal com uma faca" ("A Tear in the Fabric: the James Bulger Murder e New TheatreWriting in the Nineties", New Theatre Quarterly, 20(4) (2004), p. 311), mas isso não é óbvio na produção do Teatro Royal Court e tampouco é indicado por meio de rubricas. Alan Sinfield defende que a peça trata de questões como sadomasoquismo e consentimento (Alan Sinfield, Out on Stage: Lesbian and Gay Theatre in the Twentieth Century (New Haven and London: Yale University Press, 1999), p. 353).

${ }^{170}$ Fuck money. Fuck it. This selling. This buying. This system. Fuck the bitching world and let's be ... Beautiful. And happy' (p. 39).
} 
personagem, como sugere a elipse de Ravenhill. Robbie está nesse momento recontando a sua experiência enquanto sob o efeito de ecstasy, e descrevendo aqueles sentimentos que o levaram a distribuir gratuitamente a droga que pertencia a Brian. Como resultado da ação, Robbie se aprisiona ainda mais profundamente no "sistema" de compras e vendas, e Mark é levado a mutilar Gary.

Ao ouvir que ele distribuiu gratuitamente as pílulas, Lulu desiste de cuidar dos hematomas de Robbie, e começa a agredi-lo com xingamentos e tapas a fím de, em seguida, concluir: "homens e mulheres fazem o futuro. Há pessoas lá fora que precisam de mim. Pessoas normais que fazem sexo tipo certinho e quando querem. E os meninos? Os meninos só fodem um ao outro" (p. 39-40) ${ }^{171}$, arremessando a garrafa de desinfetante nos olhos do personagem.

A agressão física e verbal, atípica ao padrão de comportamento da personagem Lulu é, como o uso do antisséptico aplicado em Robbie, um meio de utilizar o que está à mão para se defender. Pelas circunstâncias descritas na rubrica do início da cena, em que Lulu masturba Robbie, a postura da personagem também pode ser interpretada como de ciúmes. A expressão dos sentimentos dela funcionam como um clichê que trata a sexualidade gay como algo infantil e descomprometido com o futuro da humanidade.

Lee Edelman (2004) usa o termo "futurismo reprodutivo" a fim de se referir a esse tipo de discurso empregado por Lulu e que também pode ser visto nas falas de outros personagens de Ravenhill, como nos de Pool, em seus momentos finais, e que torna central a figura "da criança/do filho" para o desenvolvimento de tal argumentação. No entanto, o argumento de Edelman sobre essa figura e a sua importância o autoriza a falar

\footnotetext{
${ }^{171}$ Boys grow up you know and stop playing with each other's willies. Men and women make the future. There are people out there who need me. Normal people who have kind tidy sex and [sic] when they want it. And boys? Boys just fuck each other.
} 
sem complicações sobre "uma cultura homofóbica" que deve ser recusada por meio de uma identificação com a pulsão de morte, na qual, de certo modo, o futuro inexiste. Por sua vez, Ravenhill direciona a nossa atenção para as contradições do posicionamento gay na sociedade contemporânea ${ }^{172}$.

Quando Lulu afirma que "meninos só fodem”, a alusão ao título da peça ajuda a enfatizar que a sexualidade (gay) tem se mostrado facilmente mercantilizada e - por razões históricas precisas ${ }^{173}$ - sido integrada à lógica da sociedade capitalista ao mesmo tempo em que essa mesma integração continua a ser uma maneira de banalizá-la, pois o fetichismo do reino "privado", familiar, contrapõe-se-lhe como o loco privilegiado das verdadeiras relações humanas.

Ravenhill é cuidadoso ao minar toda idealização de normalidade familiar ${ }^{174}$ : o sexo domesticado ao qual Lulu alude - porque, apesar de tudo, ela precisa se sentir querida - oferece-lhe apenas uma segurança frágil; e, nas demais partes da peça, o relacionamento sentimental de Brian com o filho contrasta com o modo como se relaciona com os demais personagens e com o papel de pequeno traficante que viabiliza a sua relação parental.

Apesar disso, a interação entre, de um lado, a sexualidade gay e, do outro, o tipo de mundo pós-moderno, representado por Ravenhill, ganha força por meio de uma das diversas narrativas ficcionais ou fantasiosas que são recontadas com certas variações ao longo da peça. Na fala do personagem Mark, a ação se emoldura no seu formato derradeiro. Em um mercado pós-apocalíptico, um mutante, do tipo escravo sexual, - uma

\footnotetext{
${ }^{172} \mathrm{O}$ engajamento mais evidente de Ravenhill segundo essa lógica aparece na peça Handbag (2016), na qual a mudança da constituição e reprodução do modo familiar é registrado. Nela, dois casais gays, um masculino e outro feminino, juntam forças a fim de terem e criarem um filho.

${ }^{173}$ David T. Evans defende que, após a descriminalização parcial, o mercado foi a única parte da sociedade civil capaz de acomodar o crescimento das interações sociais dos gays do sexo masculino. Ver Sexual Citizenship: The Material Construction of Sexualities. London and New York: Routledge, 1993, p. 89113.

${ }^{174}$ São muitos os críticos que observaram entre os personagens Robbie, Mark e Lulu uma espécie de relação familiar. Para mais informações ver, por exemplo, ROBERTS, 2001.
} 
paródia $^{175}$ do corpo gay propagada pelo mercado, com um peitoral perfeito e um pênis enorme - teme a liberdade que Mark, o seu mestre, atribui-lhe, crendo que morrerá em virtude disso. Futurista e distópica - contada de uma maneira que enfatiza um lado cinemático -, a narrativa serve para confirmar uma incapacidade tanto de autonomia quanto de reciprocidade (“estamos no ano três mil e blábláblá"). A peça termina como começou, com os personagens dando de comer uns aos outros a comida pré-pronta: a intimidade imatura de Lulu, Mark e Robbie vem à tona enquanto interagem com o alimento industrializado.

Os personagens de Ravenhill tendem passivamente a expressar a lógica dos processos sociais e discursos que os “constroem”, expressão esta que funciona a serviço da peça. Há uma inquietude nessa constatação, o próprio Ravenhill (2005, p. 311) afirma que não deseja que seu trabalho seja interpretado como um olhar passivo. Em relação a $S F$, ele defende, por exemplo, que:

Eu sempre escrevi contra o relativismo moral. Eu quero que os espectadores façam escolhas morais: decidindo a todo momento intelectual e emocionalmente - se o que os personagens estão fazendo e decidindo está certo ou errado. Eu acho isso teatral. Isso dá bom teatro... escrever contra os nossos tempos repletos de ironia e despreocupação onde qualquer tipo de hierarquia de valores se esvai, encenar algo que faz as pessoas dizerem, "isso é errado" tem me deixado muito satisfeito... a permissão de dizer, "isso é errado" - sem qualificação - leva-nos um passo mais perto do "isso é certo". E de mudarmos.

\footnotetext{
175 A paródia se aproveita da singularidade de determinados estilos a fim de incorporar suas idiossincrasias e criar uma imitação que simula o original de um modo comumente satírico. Segundo Fredric Jameson (2006, p. 23), "a paródia é a imitação de um estilo peculiar e único".
} 
O problema é que o dramaturgo responde, assim, ao pedido de um certo tipo de espectador que espera condenar as ações dos personagens. Estes, por sua vez, parecem estar presos a uma armadilha, sem opções.

Muito da ironia advinda de Ravenhill serve como meio de lisonjear a plateia e fazê-la se sentir superior aos personagens. Por isso, toda crítica dirigida ao sistema arrisca ser neutralizada por despertar um sentimento de desdém contra um tipo de grupo social com características, até certo ponto, identificáveis: os "afeminados", contra os quais as imagens negativas da peça se direcionam.

Quando $S F$ se transferiu para o Teatro Royal Court, em Londres, a peça conquistou uma plateia em larga medida gay, cosmopolita e jovem, mas Ravenhill estava aparentemente consternado por aqueles que reagiram como se a peça fosse feita para ser “irônica, fria, insensível”" ${ }^{176}$. Não é fácil concordar com o dramaturgo quando ele afirma que os espectadores reagiram "erroneamente". Talvez tenha sido melhor concluir que a direção ou a concepção da peça tenha sido inadequada ou, então, concebida para um outro perfil de espectador ou que tenha havido falha da produção. Porém, num outro sentido, a peça é assertiva: homoafetivos ou biafetivos estão tão atrelados à lógica do consumismo quanto heteroafetivos, assim como podem igualmente demonstrar falta de senso histórico, político e social em relação ao mundo em que vivem.

\subsection{Shopping and Fucking e Pool (no water): entre Gay e Queer}

A distinção entre os termos "queer" e "gay" pode parecer redundante se tomados inadvertidamente como sinônimos. No entanto, a compreensão de suas diferenças é pertinente aos estudos voltados para as peças de Ravenhill, assim como para as produções e os estudos culturais contemporâneos. O termo autorreferente "gay" foi adotado de

\footnotetext{
${ }^{176}$ SIERZ, 2000, p. 129.
} 
maneira deliberada, nos EUA, em 1969, após o episódio que se tornou conhecido como Stonewall liberation movement ou Gay liberation front ${ }^{177}$, e, assim, deixou de pertencer a um universo, outrora, considerado subcultural ou encoberto.

Já o termo "queer" passou a ser reconhecido juntamente com a tomada de consciência advinda do alastramento do vírus HIV, e está associado a grupos radicais e ativistas como o Act-Up (AIDS Coalition to Unleash Power, na sigla). Esse grupo foi formado em 1989 e, desde então, divide a sua sede com outra organização norteamericana importante, a Outrage. Entre as suas principais finalidades, a Act-Up funciona como uma organização ad hoc que usa estratégias teatrais a fim de despertar a consciência para questões relacionadas ao universo queer ${ }^{178}$. Esse termo rejeita deliberadamente o vocábulo "gay" e o seu vínculo com indivíduos de origem branca e classe média que, dependentes de uma cultura dominante, subjugam-se a uma espécie de vida em gueto. Há também quem entenda o termo "queer" como eco do movimento "gay" em sua rápida transformação de força subversiva a uma esfera relacionada àquilo que é da ordem do chique ou fashion -, orientando-se de acordo com as forças colonizadoras do comércio e da mídia.

A reapropriação do termo "queer", outrora usado com conotação ofensiva, vincula-se também a uma rápida expansão dos intitulados Queer Studies, que se desenvolveram a partir dos estudos da cultura gay e lésbica, majoritariamente liderados por acadêmicos norte-americanos. Os Queer studies se debruçam sobre as políticas, as teorias culturais e a estética queer, defendendo que os elementos relacionados à

\footnotetext{
${ }^{177}$ No verão de 1969, como parte das medidas do prefeito John Lindsey de represália a estabelecimentos frequentados pela comunidade homossexuais da cidade de Nova York, nos EUA, policiais conduziram uma "batida" de rotina no bar Stonewall Inn. A resposta enérgica dos seus donos, que não se deixaram intimidar, assim como os protestos e as passeatas subsequentes, marcou uma virada no ativismo LGBT que reverberou ao longo dos anos seguintes, impactando os movimentos em prol de direitos e liberdades da população gay nos Estados Unidos. Mais em informações em: Biblioteca Pública Digital da América. https://dp.la/primary-source-sets/stonewall-and-its-impact-on-the-gay-liberation-movement. Acesso em 14 de fevereiro de 2019.

${ }^{178}$ Mais informações em http://www.actupny.org/. Acesso em 12 de fevereiro, 2019.
} 
homofobia e ao heterossexismo, assim como às suas contradições, vêm à luz quando a sexualidade considerada "desviante" é confrontada com estruturas sociais e culturais:

Tanto para acadêmicos quanto para ativistas, o termo queer, em linhas gerais, alcança o seu auge crítico ao se definir opondo-se àquilo considerado como "normal" em vez de "heterossexual", autorizandose, portanto, a contrariar o regime do "normal". Nós podemos até afirmar que as políticas queer se opõem à sociedade em si [, às suas regras, às suas normas]. ${ }^{179}$

Temas como sexualidade e "energia sexual" influenciam leituras culturais e tendem a assumir uma noção conformativa e normativa da identidade. Políticas de liberdade, como defendidas pelos movimentos gay, estavam preocupadas com a identidade (homos)sexual, mas assumiam "o domínio social de um sistema de papeis mutuamente exclusivos em torno de orientações sexuais (homossexual/heterossexual) e gêneros (masculino/feminino)"180.

Essa hipótese se baseia na ideia de que a orientação sexual é a única diferença significativa que contraria ou assume a inclusão de diferenças relacionadas à classe social, raça, etnia, idade, preferência sexual e localização geográfica. Na tentativa de desafiar o sistema por meio da individualização, ativistas inadvertidamente perpetuaram noções fragmentadas de identidade junto a uma linha de oposição binária, e não foram capazes de reconhecer outras múltiplas diferenças envolvidas.

O pensamento que sustenta a teoria queer defende uma mudança de foco, desviando-se "das políticas de identidade para uma política de significação"181 - ou seja, vislumbrando "uma visão da identidade como diferença"182. Todavia, diferença também

\footnotetext{
179 WARNER, 1993, p. xxxi-vii.

${ }^{180}$ SEIDMAN, S. In WARNER, op. cit., p. 129.

181 Ibid., p. 130.

${ }^{182}$ FUSS, 1989, p. 102-3.
} 
implica alteridade; a fim de que, em vez de uma tentativa de construção de uma identidade gay monolítica, houvesse uma análise transformadora da identidade em relação a suas significações e possíveis leituras múltiplas.

No geral, nem tudo, no teatro, entendido como gay se tornou queer. Apesar disso, produções como Shopping and Fucking e Pool (no water) são evidências de que o teatro é capaz de transitar por questões relacionadas a esses dois termos. Na passagem da primeira peça para a segunda, mais tardia, é possível, por exemplo, ver a identidade sexual como sendo até certo ponto cambiável ou, até mesmo, indefinida, pois, na montagem de estreia, os personagens A, B, C e D, sendo dois atores e duas atrizes, revezam-se no papel da amiga acamada num leito de hospital. Nesse sentido, o espectador verá, em certos momentos, um ator no papel da personagem ausente enquanto uma atriz fará o papel de um amigo do sexo masculino, violentando-a. É possível afirmar também que a escolha por letras para nomear os personagens dificulta no texto dramatúrgico o reconhecimento por sexo ou gênero dos personagens.

Compreender a relação entre os personagens representantes do gênero feminino e as figuras simbólicas do "homem gordo" e da "figura paterna", em $S F$, e da personagem ausente, em Pool, é, de certo modo, analisar formalmente o contexto encontrado nas duas peças, assim como uma formação social na qual predomina a violenta sujeição que os homens impõem às mulheres no mundo contemporâneo. Tanto em $S F$ quanto em Pool, os personagens expressam emoções, muitas vezes, descontroladas e próprias do polo tido (numa visão sexista) como feminino: são imaturos, egoístas, tornando-se deliberadamente amorais e vingativos na peça Pool. 
Quanto à relação entre Robbie, Mark e Gary, pode-se inferir que a homoafetividade em $S F$ representa também a passividade e a fragilidade "típicas" do universo feminino. O sentimento de alienação não só é atribuído ao significado da palavra “gay”, como vimos nas análises desse subcapítulo, mas, também, à caracterização desses personagens. No geral, a sexualidade faz menção a uma existência e a relações socias tidas como mercantilizadas e superficiais, algo que, embora ocorra de maneira mais evidente em $S F$, também é visto em Pool. A forma fragmentada/massificada, alienada e ao mesmo tempo frágil dos personagens passa indubitavelmente por questões envolvendo gênero e sexualidade num mundo tanto machista e homofóbico quanto direcionado ao consumismo. 


\section{Considerações finais: Teatro In-Yer-Face, liberalismo e sociedade}

O tom político da era Margareth Thatcher nos anos 1980 tem uma influência significativa em $S F$ e efeitos que se desdobram em Pool. Ravenhill (apud SIERZ, 2000, p. 132) reconhece a crítica implícita à declaração da primeira-ministra segundo a qual sociedade é algo que não existe: "Se a visão dela é verdadeira, o resultado é este: uma atitude 'cínica e endurecida', irritada com o fato de que o 'sentido de sociedade desapareceu'",183.

Embora a administração Thatcher tenha servido de inspiração para Ravenhill ao ter escrito $S F$, segundo críticos, como Wallace (2005) $)^{184}$, isso não é suficiente para considerá-la uma peça genuinamente política. Isso porque o ponto de vista capitalista de Brian, por exemplo, prevalece e a peça acaba sendo pouco esperançosa no que se refere a mudanças no sistema econômico.

Na última cena, esse personagem expressa satisfação com o fato de Lulu e Robbie terem adotado o lema "dinheiro é civilização, e civilização é dinheiro". O fato de Brian devolver o dinheiro que Lulu e Robbie lhe deviam pode parecer algo positivo, mas ele somente o fez "porque vocês [Robbie e Lulu] aprenderam a lição, entende? Vocês compreenderam o que significa isso (Mostra a valise), e vocês agora são civilizados” (p. 87). A ironia presente, de tipo (pseudo)moralizante, que afirma uma coisa dizendo o contrário, tem efeito de recurso didático às avessas.

Apesar de o desejo de mudar de vida parecer insignificante, alguns personagens atacam à sua maneira o sistema vigente. Robbie, por exemplo, revolta-se contra o

\footnotetext{
183 Posteriormente, o Partido Trabalhista, mesmo à esquerda, também tomou medidas conciliatórias ou condizentes com os momentos de crise.

${ }^{184}$ [...] Ravenhill never presents any convincing alternative, while his satire is weakened by either reliance on sentiment, or on unlikely or hasty character transformation (p. 275).
} 
sofrimento e as guerras no mundo e evoca algum tipo de mudança: "Foda-se.[...]. Nada de sistema. Foda-se essa porra desse mundo e vamos ser... lindos" (p. 39) ${ }^{185}$. Mesmo assim, ele não é capaz de apresentar uma solução apropriada.

A falta de objetivos políticos e a inércia e a anomia em que se encontram mergulhados os personagens é um dos procedimentos provocativos não só de $S F$ mas, também, de Pool: os personagens não reclamam (ajuda) do governo, não reivindicam auxílio-desemprego, muito menos possuem um vocabulário politizado. O vocabulário deliberadamente político inexiste nas peças e levam a plateia a se equilibrar entre sentimentos conflitantes de empatia e crítica em relação aos personagens e a si mesma. Em $S F$, o ponto de vista capitalista de Brian é mostrado de forma convincente, ao mesmo tempo em que o personagem funciona como uma figura desestabilizadora quanto ao relacionamento triangular mantido entre Mark, Robbie e Lulu.

$S F$ pode não oferecer uma solução concreta sobre como melhorar a situação. No entanto, a peça tem claramente uma pauta política ao tocar em questões sociais, econômicas e morais contemporâneas, criticando-as. O desvelamento da alienação dos personagens sem disfarces é a própria crítica política de $S F$. Somada a ela, o potencial crítico da peça se erige também sobre as diversas formas de estranhamento causadas, por exemplo, pela violência (narrada em meio aos diálogos ou cenicamente explicitada) de diversas das cenas, assim como pela fragmentação, a predominância do tema sobre o enredo e a inverossimilhança dos personagens atrelados ao formato anti-ilusionista explícito tanto de $S F$ quanto Pool.

A agressividade onipresente nos leva a questionar certas normas morais, e expõe o ceticismo ligado aos valores enfatizados pelo governo Thatcher e o liberalismo

\footnotetext{
${ }^{185}$ Fuck it. [...]. This system. Fuck the bitching world and let's be ... beautiful.
} 
econômico, como, por exemplo, o dever de se ganhar dinheiro: a ação de trabalhar com a finalidade única de acumular recursos e, então, consumir. Em Pool, a representação de personagens como partícipes de um "grupo", distinguíveis textualmente uns dos outros apenas por meio de iniciais alfabéticas, ajuda a agravar ainda mais o resultado do que já havia se tornado a vida social em $S F$ conforme, na passagem de uma peça para a outra, os personagens envelhecem e se sentem ainda mais brutalizados pelos efeitos de não terem um emprego formal ou não serem reconhecidos profissionalmente. Se, em $S F$, os jovens são alienados, em Pool, os personagens mostram-se já em um estágio subsequente, tendo aderido totalmente ao sistema. A especificidade das peças está no modo como elas, desviando-se do discurso politizado, se tornam peças políticas, mas constituídas de outra forma.

\subsection{A predominância dos temas e a subversão das formas}

$S F$ faz referência ao universo de uma grande metrópole, provavelmente, inglesa (Londres? Manchester?), enquanto Pool oscila entre um passado um pouco mais distante dos personagens vivido em uma grande metrópole também inglesa e um outro mais recente em que estaria localizada num "paraíso distante" a casa da amiga. Ao final, os personagens também falam de alguma região localizada no interior, provavelmente da Inglaterra, em que teriam constituído as suas famílias.

A aparente trivialidade exposta no primeiro plano da trama de $S F$ e de $\mathrm{Pool}$ - na primeira peça, as vidas errantes de um adolescente, três jovens adultos e um adulto tentando sobreviver numa metrópole inglesa, no final de 1990, consumindo/devorando o que for possível; e, na segunda, as vidas de A, B, C e D empobrecidos e vivendo à sombra da fama de uma amiga famosa (ausente) - deixa sobressair, na engrenagem formal das peças, seus respectivos movimentos histórico-sociais, de grande interesse. Importando 
mais do que o desdobramento das ações individuais e o resultado em si, as temáticas dessas obras abordam a (re)produção da sociedade pós-moderna, em que "o capitalismo não é mais relativizado por um possível horizonte de superação" (SCHWARZ, 2012, p. 79), no que isso guarda de mais pessimista ${ }^{186}$ : um futuro de mudanças não faz parte do horizonte desses personagens.

Diferentemente de certa praxe no drama burguês, o contexto histórico em $S F$ e em Pool não é um mero pano de fundo e interfere radicalmente na essência das relações tecidas entre os personagens. No caso do drama, como observou Szondi (2001, p. 34), há sempre uma "dialética intersubjetiva", e, por isso, uma construção da verdade criada essencialmente a partir dos diálogos. Nessas duas obras do dramaturgo inglês, as relações intersubjetivas revelam-se severamente fragilizadas na primeira obra e quase inexistentes na segunda, e isso se reflete formalmente no contexto em que se encaixam os personagens.

Os diálogos reconfigurados em variações de polílogos ${ }^{187}$ sujeitam os personagens a um movimento truncado e circular em $S F$ e a uma quase estagnação do presente devido ao deslocamento contínuo para o tempo passado em Pool. Formalmente, as peças nos fazem estranhar o que nos parece mais natural em nosso dia a dia, aprofundando, com certo ar de inocência em $S F$ e de mágoa em Pool, temas enviesados entre o drama

\footnotetext{
${ }^{186} \mathrm{O}$ trecho entre aspas faz parte da análise do contexto cultural brasileiro posterior à contrarrevolução em 1964-70 e, ainda, explica bem a passagem do mundo moderno para o pós-moderno em suas linhas gerais. "Conforme sugere Nicholas Brown, um estudioso americano do Brasil, da globalização, da bossa nova e do tropicalismo, a vitória da contrarrevolução em 1964-70, com a decorrente supressão das alternativas socialistas, havia propiciado a passagem precoce da situação moderna à pós-moderna no país, entendida esta última como aquela em que o capitalismo não é mais relativizado por um possível horizonte de superação", afirma Schwarz.

${ }^{187} \mathrm{Em}$ ambas as peças, o centro da relação interpessoal foi deslocado para o homem só, isolado, havendo nelas um dialogismo de menor dimensão denominado, segundo Sarrazac (2017, p. 205), de "polílogo" e que sintetiza uma solidão "polifônica" dos personagens. Em $S F$ e Pool, essa instância do diálogo encontrase entremeada por descrições narrativas e criam uma tensão entre um movimento do drama para frente, que persiste, e uma força de resistência, até mesmo contrária, que se impõe e que resulta num movimento de "desdramatização".
} 
individual e o sofrimento coletivo dos personagens. As questões aparentemente relacionadas a escolhas individuais são, na verdade, problemas vividos e enfrentados coletivamente: em $S F$, o consumo alienado de bens, a forma mercantilizada das nossas relações (públicas e) privadas, o individualismo antissocial etc.; e, em Pool, a relação com as práticas artísticas, o enfraquecimentos dos laços sociais e de amizade e as motivações profissionais motivadas apenas por um sentimento de ambição extrema e de sucesso a todo custo que, somados, levam ao insulamento e anulação do indivíduo. Ao baixar o pano, chegamos à conclusão de que a relevância das peças está mais nos temas, formalmente radicalizados, do que na ação dos enredos ou no destino individual dos personagens.

Nas duas peças, a todo instante, o palco sugere o questionamento em torno da nossa relação com a violência que lhes são inerentes, algo que não pode ser analisado com base, apenas, na responsabilidade individual. Seguindo as análises de Slavoj Zizek (2008, p. 2), são três os tipos de violência. A subjetiva, mais visível, é realizada por agentes identificáveis, sendo "vista como uma perturbação do 'normal', do estado pacífico das coisas". A objetiva, também chamada de sistêmica, é definida "precisamente como a violência inerente a este 'normal' estado das coisas", composto "geralmente pelas catastróficas consequências do funcionamento de nosso sistema econômico e político”. E a simbólica, a "mais fundamental forma de violência [...] pertence à linguagem como tal, por sua imposição de um certo universo de significado".

A violência objetiva, sistêmica, gera respostas subjetivas que, nas peças, ficam a meio caminho e acabam se perdendo em ações pouco efetivas dos personagens. Por sua vez, a violência simbólica funciona bem e os significados criados no palco reverberam, levando-nos a refletir sobre as condições estabelecidas entre vida material e encenação que tornam aquela violência necessária. 
As mercadorias presentes na trama de $S F$ aparecem completamente destituídas de qualquer caráter social, ou seja, como se elas não fossem detentoras de qualquer trabalho humano, como se brotassem do chão, naturalizando o consumismo. Ainda nessa mesma obra, o alimento vital, servido nas refeições, por exemplo, foi transformado em comida congelada (para micro-ondas), pasteurizada, multiétnica, repleta de sabores artificiais alegoria esta da fetichização daquilo que nos é mais essencial. A sexualidade, como retratada, assim como a comida, possui dois lados: de produto mercantil e de necessidade biológica. Ademais, os personagens estão sempre buscando vender ou comprar algo, e sempre sem dinheiro, vivendo na lacuna de um mundo em constante crise.

Na comparação com os personagens de $S F$, os de Pool envelheceram. E o próprio fato de terem envelhecido os levou a ações que, de inocentes ou ingênuas, como nas encenadas na primeira peça, passaram a ambiciosas, rancorosas e ainda mais egoístas nas da segunda peça. Em $S F$, os personagens se conectavam mesmo aos trancos por um vínculo ainda afetivo, e os diálogos fragmentados e muitas vezes superficiais, repletos de descrições narrativas, proporcionavam-lhes mesmo de maneira limitada a possiblidade de agir. Por sua vez, a radicalização da forma em Pool, materializada por meio de personagens sem traços individuais ou qualquer profundidade psicológica, "interagindo" por meio de diálogos difusos, voltados para o passado, e não atrelados a um detentor específico da fala contrapõem-se a temas como o da pauperização da arte e do enfraquecimento dos laços de afetividade em prol das relações movidas por competição e interesses econômicos. A constituição da família idealizada, ao final, resume a vida dos personagens: casados, com filhos e vivendo numa casa com piscina montável, o que retrata uma retomada dos valores burgueses conservadores apreciados e defendidos na era Thatcher. 
Em Pool, é precisamente a ascensão do "princípio masculino”, representado pela personagem ausente, que produz "a perda da dimensão sensível das relações humanas", pois o seu sucesso profissional e financeiro, no final, antagoniza com o confinamento doméstico e a repressão dos demais personagens, que assumem o papel da "esposa padrão"188. Em $S F$, a representação simbólica da "figura paterna" ou do "homem gordo" são as verdadeiras detentoras do capital, algo que caracteriza os demais personagens como representantes do lado feminino. A relação homoafetiva entre Robbie, Mark e Gary também alude às características comumente associadas ao universo feminino, na relação patriarcal: com poucos recursos financeiros, frágil e inseguro. Se, em $S F$, a individualidade é minimamente preservada, em Pool, o fato de a personagem ausente representar ao final o polo masculino corrobora a constituição massificada de A, B, C e D na forma de "impersonagem"189.

$S F$ sintetiza cena após cena o sentimento dos personagens e daquele universo em que tudo se tornou um simulacro da vida real (a imagem do sangue, escorrendo em diversas passagens, que se vê e não se sente) que aparece como algo impossível de ser representado. E Pool transparece em sua longa cena o estado de apatia ou indiferença presente. A dor sofrida pela artista lesionada não se traduz na compaixão humana dos seus amigos mas em uma possibilidade de representar aquela situação "artisticamente”.

A centralização do enredo de Pool na ausência da amiga famosa sugere que tanto os personagens sobre o palco quanto os espectadores juntam-se numa busca representada

\footnotetext{
188 Segundo Scholz (2008, p. 2), “é precisamente a ascensão do principio masculino do 'trabalho abstrato como um tautológico fim em si mesmo' que traz como resultado o confinamento doméstico e a repressão da mulher na história ocidental, produzindo, ao fim e ao cabo, a perda da dimensão sensível das relações humanas, a destruição da natureza e a ameaça de guerra nuclear".

189 Há três dispositivos principais por meio dos quais o roteiro de Pool fortalece a constituição do “impersonagem”: primeiro, a negação de falantes identificáveis presentes na peça; segundo, a instabilidade gerada pelo "falso" diálogo e a fala ininterrupta; e, finalmente, a transgressão da normatividade dos gêneros masculino e feminino a favor da indeterminação e de uma certa fluidez que leva à conclusão de que a personagem ausente se associa ao polo historicamente definido como masculino.
} 
por uma espécie de identidade ou individualidade que na peça se perdeu. É por meio dessa força propulsora exercida pela personagem ausente sobre os demais, assim como por meio das descrições narrativas e ficcionais presentes em $S F$ - apesar de, muitas vezes, incoerentes - que se manifesta a verdade, por mais rasa que possa parecer. Na medida em que $S F$ e Pool pretendem oferecer maior autonomia a essas dimensões mais íntimas e racionalmente menos articuladas do pensamento, impõe-se, como diria Rosenfeld, "qualquer tipo de solução mais ou menos épica"190: "vocês sabem como a vida é dura neste planeta. Intratável. Eu digo isso porque sinto na própria pele”, afirma Brian, em $S F^{191}$.

Ignorar a qualidade técnica de Ravenhill atrelada à importância desses dois mecanismos - as estorinhas, em $S F$, e a personagem ausente, em Pool - causaria à leitura das peças uma falha estrutural grave. Em Pool, a personagem ausente funciona como o gatilho para uma percepção de que o tempo parou nas vidas de $\mathrm{A}, \mathrm{B}, \mathrm{C}$ e $\mathrm{D}$; em $S F$, as “estorinhas", fazem as vidas, sobretudo, de Lulu, Robbie e Mark andar aos trancos a fim de voltar, na última cena, ao ponto de partida do enredo. São esses recursos os principais responsáveis por destacar a diferença entre o mundo virtual/fora das peças e o real, materializado no palco: ao primeiro universo, atribui-se frequentemente as promessas de prosperidade típicas do discurso neoliberal e, ao segundo, a condição crescente de miséria social em que se encontram os personagens. A radicalização das formas tanto dos personagens quanto dos diálogos é resultado, na mudança de uma peça para a outra, da exposição de indivíduos gradativamente mais fragmentados num sistema de relações sociais cada vez mais enfraquecido.

\footnotetext{
${ }^{190}$ Cf. ROSENFELD, 2008, p. 125.

${ }^{191}$ You know, life is hard. On this planet. Intractable. I can tell you this because I feel it. (p. 86)
} 


\section{Referências $^{192}$}

ADORNO, T. Minima moralia: reflexões sobre a vida danificada.2. ed. São Paulo: Ática, 1993.

ADORNO, T. Trying to Understand Endgame in Samuel Beckett: Longman Critical Reader, eds. Jennifer Birkett and Kate Ince, Essex: Pearson Education, 1999.

Indústria Cultural e Sociedade. São Paulo: Paz e Terra, 2002.

Teoria Estética. Lisboa: Edições 70, 2008.

ALDERSON, D. (2010). Postgay drama: Sexuality, narration and history in the plays of Mark Ravenhill. Textual Practice, 24(5), 863-882.

ANDERSON, P. As origens da pós-modernidade. Rio de Janeiro: Jorge Zahar,1999.

Components of the national culture. New Left Review, London:

Verso, v. 1, n. 50, p. 03-57, Julho/Agosto 1968.

ARANTES, P. Zero à esquerda. São Paulo: Conrad, 2004.

ARISTÓTELES. Poética. In: Os pensadores. São Paulo: Abril, 1973.

ARTAUD, A. The Theater and Its Double. New York: Grove Press Inc., 1958.

O teatro e seu duplo. São Paulo: Martins Fontes, 2006.

ATTRIDGE, D. The Singularity of Literature. London: Routledge, 2004.

BALCOM, K. E. (2012). Martin McDonagh's spatial narratives and the reinvention of theatrical heterotopias (Order No. MR90694). Available from ProQuest Dissertations \& Theses Global. (1220474821). Retrieved from https://search.proquest.com/docview/1220474821?accountid=17256

BARNETT, D. "When Is a Play Not a Drama? Two Examples of Postdramatic Theatre Texts." New Theatre Quarterly 24.1 (2008): 14-23. http://dx.doi.org/10.1017/S0266464X0800002X.

BATHURST, L., \& University of Leicester. (2005). Contemporary Gay Drama : The End of a Modern Crusade?

BAUDRILLARD, J. Sociedade de consumo. Lisboa: Edições 70, 2008. ; POSTER, M. (ed). Selected Writings. Cambridge: Polity Press, 1988.

192 De acordo com a Associação Brasileira de Normas Técnicas. NBR 6023. 
BAUMAN, Z. Vida para o Consumo: A Transformação das Pessoas em Mercadorias. Rio de Janeiro: Zahar, 2007.

BENEDICT, D. (2006, Nov). Legit reviews: Abroad: "pool (no water)". Variety, 404, 60. Retrieved from https://search.proquest.com/docview/1964755?accountid=17256

BENJAMIN, W. Obras escolhidas: magia e técnica, arte e política. São Paulo: Brasiliense, 1987.

BENJAMIN, W. Understanding Brecht. London: Verso, 1983.

BENTLEY, E. O dramaturgo como pensador: um estudo da dramaturgia nos tempos modernos: Wagner, Ibsen, Strindberg, Shaw, Pirandello, Sarte, Brecht. Rio de Janeiro: Civilização Brasileira, 1991.

BETTI, M. S. Texto e Cena: Uma Introdução à Análise do Texto Teatral. Núcleo de Estudos Teatrais Décio de Almeida Prado (Centro Angle Rama). FFLCH-USP. $1^{\circ}$ semestre de 2002.

BILAC, J. Insetos. Rio de Janeiro: Cobogó, 2018.

BILLEN, A. (2009). The paradise that wasn't: Mark Ravenhill is an awe-inspiring dramatist, despite his dubious politics. New Statesman, 138(4941), 60.

BILLINGTON, M. State of the nation: British theatre since 1945. London: Faber and Faber, 2007.

BLOOM, Adi. (2004). Playwright hits out over poor reading.(Mark Ravenhill criticises changes to education)(News). Times Educational Supplement, (4604), 3.

BOCHOW, J. (2015). Locating History on the Contemporary Stage. Journal of Contemporary Drama in English, 3(1), 156-173.

BOIREAU, N. (2014). Rewriting the Nation. British Theatre Today. Études Anglaises, 67(2), 233-236.

BOLES, W. C. Violence at the Royal Court: Martin McDonagh's The Beauty Queen of Leenane and Mark Ravenhill's Shopping and Fucking. Theatre and Violence 7 (1999): 125-135.

BRYAN, R. A. (2006). From the voice to the violent act: Language and violence in contemporary drama (Order No. 3236571). Available from ProQuest Dissertations \& Theses Global. (304981536). Retrieved from https://search.proquest.com/docview/304981536?accountid=17256

BJUGGFALT, M. (2017). Beyond Morality: Alternative Gay Narratives in Mark Ravenhill's Shopping and Fucking and Dennis Cooper's The Sluts.

BUCK-MORSS, S. The origin of negative dialectics. New York: Collier Macmillan, 1977. 
BULL, J. A review of In-yer-face theatre: British drama today, em Contemporary Theatre review, vol.13, $\mathrm{n}^{\circ} 1$ (2003), p.123-5 (123).

BURGESS, A. A Literatura Inglesa. São Paulo: Ática, 1996.

BUSE, P. Mark Ravenhill. Contemporary Writers. British Council, 2003. Disponível em: $<$ http://literature.britishcouncil.org/mark-ravenhill $>$. Acesso em: 20 jan. 2013.

BUTLER, J. Bodies That Matter: On the Discursive Limits of "Sex." London: Routledge, 1993.

- Gender Trouble: Feminism and the Subversion of Identity. London:

Routledge, 2007.

. Precarious Life: The Powers of Mourning and Violence. London: Verso, 2004. 1997.

The Psychic Life of Power: Theories in Subjection. Stanford, CA: Stanford UP, . Undoing Gender. London: Routledge, 2004.

_ . "Competing Universalities." Contingency, Hegemony, Universality: Contemporary Dialogues on the Left. Ed. Judith Butler, Ernesto Laclau, and Slavoj Žižek. London: Verso, 2000. 136-81.

—. "Imitation and Gender Insubordination." 1990. The Judith Butler Reader. Ed. Sara Salih and Judith Butler. Oxford: Blackwell, 2004. 120-37.

CALLENS, J. (2003). Staging the televised (nation). Theatre Research International, 28(1), 61-78. Disponível em: https://search.proquest.com/docview/221472442?accountid=17256 . Acesso em: 03 january 2019.

CAMPOS, F. S. F. As formas do consumo no teatro político de Mark Ravenhill. 2014. 112 p. Dissertação (Mestrado) - Faculdade de Filosofia, Letras e Ciências Humanas, Universidade de São Paulo, São Paulo, 2014.

CARLSON, M. Teorias do teatro: estudo histórico crítico dos gregos à atualidade. São Paulo: UNESP, 1997.

CEVASCO, M. E; SIQUEIRA, V. L. Rumos da literatura inglesa. São Paulo: Ática, 1993.

CEVASCO, M. E. O sentido da crítica cultural, Revista Cult, edição 122, março de 2010. Disponível em: $\quad<$ http://revistacult.uol.com.br/home/2010/03/o-sentido-da-criticacultural/> . Acesso em: 10 mai. 2013.

CHEKHOV, A. Three sisters. In: The complete plays. New York: Norton, 2006. 
COLLIN, M. Altered state: the story of ecstasy culture and acid house. London: Serpent's tail, 1997.

CLARK, M. Against permissism em Delgado, M \& SVICH, C. (editores), Theater in crisis? Performance manifestos for a New Century. Manchester: Manchester university press, 2002 , p.82-8,(p.83).

COSTA, I. C.; CEVASCO, M. E. Introdução. In: JAMESON, F. Pós-Modernismo: A Lógica Cultural do Capitalismo Tardio. São Paulo: Ática, 1996.

COSTA, I. C. Sinta o drama. Petrópolis: Vozes, 1998.

CRITCHLEY, S. Very little...almost nothing: death, philosophy, literature. London: Routledge, 1997.

DE BUCK, G. Homosexuality and Contemporary Society in Mark Ravenhill's Work. Ghent, 2009. Disponível em: < http://lib.ugent.be/fulltxt/RUG01/001/379/005/RUG01001379005 2010 0001_AC.pdf $>$. Acesso em: 22 jan. 2013.

DEBORD, G. A sociedade do espetáculo: comentários sobre a sociedade do espetáculo. Rio de Janeiro: Contraponto, 2008.

DELGADO-GARCÍA, C. (2012). Subversion, Refusal, and Contingency: The Transgression of Liberal-Humanist Subjectivity and Characterization in Sarah Kane's Cleansed, Crave, and 4.48 Psychosis. Modern Drama, 55(2), 230-250.

. Rethinking Character in Contemporary British Theatre: Aesthetics, Politics, Subjectivity. Journal of Contemporary Drama in English, 5(2), 410-414.

D’MONTÉ, R; SAUNDERS, G. Cool Britannia? British Political Drama in the 1990s. New York: Palgrave, 2008.

DERRIDA, J. The law of genre. Critical Inquiry, Vol. 7, No. 1, On Narrative (Autumn, 1980), p. 55-81.

DE VOS, L. (2012). Faust Is Dead: Mark Ravenhill's View on a Posthuman Era. Neophilologus, 96(4), 651-659.

DIDEROT, D. Discurso sobre a poesia dramática. Cosac Naify. São Paulo, 2005.

DUFFY, C., \& University of Glasgow, degree granting institution. (2012). Applying Queer Theory about Time and Place to Playwriting.

DUNKER, C; AIDAR, J. L. (Org.). Zizek Crítico: Política e psicanálise na época do multiculturalismo. São Paulo: Hacker Editores, 2005. Disponível em: $<$ http://www.oocities.org/vladimirsafatle/vladi073.htm\#_ftnref25 $>$. Acesso em: 03 ago. 2013. 
EAgleton, T. (1985). Capitalism, Modernism and Post-Modernism. New Left Review, 0(152), 60.

EDELMAN, L. No Future: Queer Theory and the Death Drive. Durham: Duke University Press, 2004.

EDGAR, D. Eighth Birmingham Theatre conference paper. In: Studies in theatre productions. July 15th, 1997.

ELDRIDGE, D. In-yer-face and after. In: Studies in Theatre and Performance. Vol.23, $\mathrm{n}^{\mathrm{o}} 1, \mathrm{p} .55-58$.

EVANS, D. Sexual Citizenship: The Material Construction of Sexualities. London and New York: Routledge, 1993.

FRANTIC ASSEMBLY; Charles, Keir; Davis, Cait; Muller, Leah; Rice-Oxley, Mark. (2006). Pool (no water). (Arquivo de áudio - British Library)

FRICKER, K. (2008). Ravenhill shoots for war.(CRITIC'S NOTEBOOK)(Mark Ravenhill). Variety, 410(11), 33.

FUCHS, E. The Death of Character: Perspectives on Theater after Modernism. Bloomington: Indiana UP, 1996.

. (1985). Presence and the Revenge of Writing: Re-Thinking Theatre after

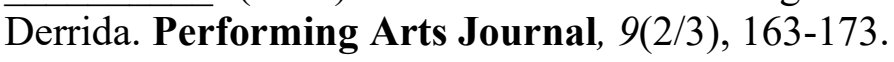

FUERY, P. The theory of absence: subjectivity, signification and desire. Westport, Connecticut: Greenwood Press, 1995.

FUKUYAMA, F. O fim da história e o último homem. Rio de Janeiro: Rocco, 1992.

FUSS, D. Essentially Speaking. London: Routledge,1989.

GREIG, D., HOLDSWORTH, N., REBELlATO, D., RIDOUT, N., \& SVICH, C. (2005). Backpages. Contemporary Theatre Review, 15(1), 156-187.

GARCIA, S. Teatro da Militância: a intenção do popular no engajamento político. São Paulo: Perspectiva/EDUSP, 1990.

GONDER, D. On the manifestation of absence in modern and contemporary american drama. Ph.d dissertation. University of Maryland College Park, 2001.

GUINSBURG, J. Da cena em cena. São Paulo: Editora Perspectiva, 2001.

GROSSI, S. A. Short Curts de Robert Altman: atalhos para a as formas de ilusão contemporâneas. 2007. 124 p. Dissertação (Mestrado) - Faculdade de Filosofia, Letras e Ciências Humanas, Universidade de São Paulo, São Paulo, 2007. 
HABERMAS, J. Mudança estrutural da esfera pública: investigações quanto a uma categoria da sociedade burguesa. Rio de Janeiro: Tempo Brasileiro, 2003.

HARVEY, D. The condition of postmodernity: An enquiry into the origins of cultural change. Malden, MA: Blackwell, 1990.

HEIDEGGER, M. The question of being. New York: Twayne, 1958.

HERMAN, J. New York Entertainment, January 26, 1998. Esse artigo pode ser encontrado em http://nymag.com/nymetro/arts/features/2160/

HORAN, T. (2012). Myth and Narrative in Mark Ravenhill's Shopping and Fucking. Modern Drama, 55(2), 251-266.

HORKHEIMER, M. Teoria Tradicional e Teoria Crítica. In: Os Pensadores. São Paulo: Abril Cultural, 1980.

HORKHEIMER, M; ADORNO, T. W. Dialética do esclarecimento. Rio de Janeiro: Jorge Zahar, 1985.

HUYSSEN, A. After the Great Divide: Modernism, Mass Culture, Postmodernism. Bloomington: Indiana UP, 1986.

INCHLEY, M. (2012). Hearing Young Voices on the London Stage: 'Shit Bein' Seventeen Int it? Never Take Us Serious'. Contemporary Theatre Review, 22(3), 327343.

INNES, C. Modern British Drama. Cambridge: Cambridge, 1992.

JAMESON, F. A virada cultural: reflexões sobre o pós-moderno. Rio de Janeiro: Civilização Brasileira, 2006.

As marcas do visível. Rio de Janeiro: Graal, 1995.

Paulo: Ática, 1997.

Pós-Modernismo: A lógica cultural do capitalismo tardio. São O método Brecht. Petrópolis: Vozes, 1999.

JÜNGER, E. Über die linie. Frankfurt-am-Main: Vittorio Klostermann, 1958.

KENYON, M. In: URBAN, K. An ethics of catastrophe: The theater of Sarah Kane. Performing arts journal. N69 (2001), p.36-46 (p.39).

KERSHAW, B. (2001). Oh for Unruly Audiences! Or, Patterns of Participation in Twentieth-Century Theatre. Modern Drama, 44(2), 133-54.

KINAS, F. Carta Aberta: uma peça conferência. Sala Preta, v. 5, p. 209-214, 28 nov. 2005. 
KOSTIC, M. (2011). Pop Culture in Mark Ravenhill's Plays Shopping and Fucking and Faust Is Dead. Brno Studies in English: Sborník Prací Filozofické Fakulty Brněnské Univerzity, S: Řada Anglisticá/Series Anglica, 37(1), 161-172.

KRACAUER, S. The mass ornament. Em Critical theory and society: a reader. London: Routledge, 1989.

KURZ, R. O colapso da modernização: da derrocada do socialismo de caserna à crise da economia mundial. São Paulo: Paz e Terra, 1996.

LACAN, J. Os nomes do Pai. Rio de Janeiro: Jorge Zahar, 2012.

LACHMAN, M. (2013). Absent Body: Ravenhill's Phenomenology of Carnality. Journal of Contemporary Drama in English, 1(1), 149-160.

LAERA, M. (2009). Mark Ravenhill's "Shoot/Get Treasure/Repeat": A Treasure Hunt in London. TheatreForum - International Theatre Journal, 3-9.

LYOTARD, J. F. The Postmodern Condition: A Report on Knowledge. 1979. Trans. Geoff Bennington and Brian Massumi. Minneapolis: U of Minnesota P,1984.

. A condição pós-moderna. Rio de Janeiro: José Olympio, 2008.

LUKÁCS, G. O romance histórico. São Paulo: Boitempo, 2011.

MACAULAY, A. “Thrills at a Price.” Financial Times (London) 30 June 1997: 19.

MARCUSE, H. One dimensional man. Boston: Beacon Press, 1966.

MAGALDI, S. O texto no teatro. São Paulo: Perspectiva, 1989.

MARTLAND, L. (2001). Misery, musicals, and Mark Ravenhill's Molly House. Back Stage, 42(40), 21.

MEDEIROS, E. O drama-da-vida e as tessituras do drama moderno brasileiro. Cadernos Letra e Ato, v. 8, p. 6-13, 2018.

MEGSON, C. (2004). 'The spectacle is everywhere': Tracing the situationist legacy in British playwriting since 1968. Contemporary Theatre Review, 14(2), 17-28.

MONFOFTE, E. (2007). English Gay/Queer Theatre in the 1990s: Kevin Elyot's My Night Will Reg and Mark Ravenhill'S Shopping and Fucking. Revista Canaria De Estudios Ingleses, 54, 195-206.

MORIN, E. (2011). 'Look Again': Indeterminacy and Contemporary British Drama. New Theatre Quarterly, 27(1), 71-85. doi:10.1017/S0266464X11000066

MORROW, S. Absent characters as proximate cause in twentieth century American drama. M.A. thesis. Georgia State University, 2009. 
MULLER, K. Political plays in England in the 19990's. Em REITZ, B. \& BERNINGER, M. (ed.). British Drama of the 1990s. Heildelberg: Universitatsverlag Carl Winter, 2002. p.15-36.

NEAMAN, E. A dubious past: Ernst Jünger and the politics of literature after Nazism. Berkley: University of California Press, 1999.

NIGHTINGALE, B. Ten with the playwright stuff. The Times. 1, May, 1996.

NIKCEVIC, S. (2005). British Brutalism, the New European Drama, and the Role of the Director. New Theatre Quarterly, 21(3), 255-272.

OVID. The Metamorphoses of Ovid. Trans. Michael Simpson. Amherst: U of Massachusetts P, 2001.

PALLOTTINI, R. O que é dramaturgia. São Paulo: Brasiliense, 2011.

PANKRATZ, A., \& DE WAAL, A. (2013). Introduction: Dissecting Bodies on Stage. Journal of Contemporary Drama in English, 1(1), 1-12.

PAVIS, P. Ravenhill and Durringer, or the entente cordiale misunderstood. Em Contemporary theater review. Vol.14, $\mathrm{n}^{\circ} 2$ (2004), 4-16 $(5,6)$.

. Dicionário de Teatro. São Paulo: Perspectiva, 2008.

PAULI, W. Die weltanschauliche Bedeuntung der modern Physik. In: DÜRR, H (Hrsg.): Physik und Traszendenz. Bern, 1990.

PEACOCK, K. D. Thatcher's Theatre: British Theatre and Drama in the Eighties. Londres: Greewood Press, 1999.

PFISTER, M. (2001). Wilde and wilder: Fin de siècle - fin de millénaire. European Review, 9(3), 355-367. doi:http://dx.doi.org/10.1017/S1062798701000333

PALLOTTINI, R. Dramaturgia: a construção da personagem. São Paulo: Perspectiva, 2015.

PORTILLO, M. (2006). Tomorrow's world: A visceral portrait of dystopia both grips and mystifies. New Statesman, 135(4783), 47.

PRADO, D. Teatro em Progresso: Crítica Teatral 1955-1964. São Paulo: Perspectiva, 2002.

. A personagem no teatro. In: CÂNDIDO, A; ROSENFELD, A; PRADO, D; GOMES, P. A personagem de ficção. 10. ed. São Paulo: Perspectiva, 2000.

QUILICI, C. S. Antonin Artaud: teatro e ritual. São Paulo: Annablume; Fapesp, 2004. 
RAGAZZI, A. Shopping and Fucking estreia hoje em São Paulo. Folha de São Paulo, São Paulo, 18 ago. $1999 . \quad$ Disponível em: $<$ http://www1.folha.uol.com.br/fsp/ilustrad/fq18089922.htm>. Acesso em: 2 mar. 2013.

RAVENHILL, M. Plays 1: Shopping and Fucking; Faust; Handbag; Some Explicit Polaroids. Londres: Methuen Drama, 2001.

. Shopping and Fucking. Tradução de Laerte Mello. Material disponível para consulta no acervo de peças da Biblioteca da Escola de Comunicações e Arte da Universidade de São Paulo. 1999.

Plays 2: Mother Clap's Molly House; Product; The Cut; Citizenship; Pool (No Water). Londres: Methuen Drama, 2008.

Plays 3: Londres: Methuen Drama, 2013.

. A Tear in the Fabric: The James Bulgur Murder and New Theatre Writing in the Nineties. Theatre Forum 26 (2005): 85-92.

. My Near Death Period. The Guardian, 26 de março de 2008. Disponível em: http://www.guardian.co.uk/stage/2008/mar/26/theatre. Acesso em: 03 mar. 2012.

. (2006). Me, my iBook, and writing in America. Contemporary Theatre Review, 16(1), 131-138.

Review, 16(3), 327-328.

(2006). That's entertainment? Contemporary Theatre Plays about men. Em EDGAR, D. (ed.) State of play: playwrights on playwriting. London: Faber, 1999.

REBELLATO, D. Introduction. In: RAVENHILL, M. Plays 1. London: Methuen drama, 2001 .

ROBERTS, M. Vanishing Acts: Sarah Kane's Texts for Performance and Postdramatic Theatre. (2015). Modern Drama, 58(1), 94-110.

ROBERTS, R. (2001) Gendered media rivalry: Television and film on the London stage.Text and Performance Quarterly, 21:2, 114-127, DOI: 10.1080/10462930128122

ROJEK, C. Decentring leisure. London: Sage, 1995.

ROSENFELD, A. O Teatro Épico. São Paulo: Perspectiva, 2008. 
$\overline{\text { Perspectiva, } 1993 .}$

História da Literatura e do Teatro Alemães. São Paulo:

O Teatro Épico. São Paulo: Perspectiva, 1985.

ROSEFELDT, P. The absent father in modern drama. New York: Peter Lang, 1996.

ROUBINE, J. Introdução às Grandes Teorias do Teatro. Rio de Janeiro: Zahar, 2003.

RYNGAERT, J P. Ler o teatro contemporâneo. São Paulo: Martins Fontes, 1998.

SAFATLE, V. Um supereu para a sociedade de consumo: sobre a instrumentalização de fantasmas como modo de socialização. Disponível em: $<$ http://www.oocities.org/vladimirsafatle/vladi073.htm\#_ftnref25 $>$. Acesso em: 03 ago. 2013.

SAKELLARIDOU, E. New faces for British political theater. Studies in theater \& performance, vol.20, $\mathrm{n}^{\mathrm{o}} 1$ (1999), p.42-53 (44).

SANTANA, J. Shopping and Fucking. Disponível em: $<\underline{\text { http://shopping-and- }}$ fucking.blogspot.com.br/> . Acesso em: 2 mar. 2014.

SARRAZAC, J. Léxico do drama moderno e contemporâneo. São Paulo: Cosacnaif, 2012.

2017.

Poética do drama moderno: de Ibsen a Koltès. São Paulo: Perspectiva,

O futuro do drama. Porto: Campos das Letras, 2002.

2013.

. Sobre a fábula e o desvio. Rio de Janeiro: 7Letras: Teatro do Pequeno Gesto,

SAUNDERS, G. Introduction. In: D’MONTÉ and SAUNDERS, p. 1-15.

SCHMITT-KILB, C. "Lifestyle Anarchism and Its Discontents: Mark Ravenhill, Enda Walsh and the Politics of Contemporary Drama." In: To Hell with Culture: Anarchism and Twentieth-Century British Literature. Ed. Gustav Klaus and Steven Knight. Cardiff: U of Wales P, 2005.

SCHWARZ, R. Martinha versus Lucrecia: ensaios e entrevistas. São Paulo: Companhia das Letras, 2012.

1978.

O pai de família e outros estudos. Rio de Janeiro: Paz e Terra,

Um mestre na periferia do capitalismo: Machado de Assis. São

Paulo: Duas Cidades; ed. 34, 2000. 
SEIDMAN, S. Identity and Politics in a 'Postmodern' Gay Culture. In WARNER, M (ed). 1993, p. 129.

SHEVTSOVA, M. (2013). A Conversation on The Wooster Group's "Troilus and Cressida" with the RSC. NTQ - New Theatre Quarterly, 29(3), 233-246.

SIERZ, A; BEAN, R; RAVENHILL, M \& STEPHENS, S. (2007). New Writing for the Theatre: A Public Discussion. Western European Stages, 19(1), 37-48.

SIERZ, A. Beyond Timidity? The state of British New Writing. Performing Arts Journal, London, v. 81, p. 55-61, 2005.

. In-Yer-Face Theatre: British Drama Today. London: Faber and Faber, 2000

. 'We all need stories': the politics of in-yer-face theatre. In: D’MONTÉ, R; SAUNDERS, G. Cool Britannia? British Political Drama in the 1990s. New York: Palgrave, 2008.

. (2008). Reality Sucks: The Slump in British New Writing. PAJ: A Journal of Performance and Art, 30(2), 102-107.

. (2011). Rewriting the nation: British theatre today (Plays and

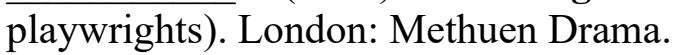

. (2002). Still in-yer-face? towards a critique and a summation. NTQ - New

Theatre Quarterly, 18(1), 17-24. Retrieved from https://search.proquest.com/docview/2115397?accountid=17256

. (2007). British New Writing Today. Western European Stages, 19(1), 4-

8.

. "The Write Stuff: The Last Time David Edgar Hosted a Conference on New Writing, He Called It 'All Passion Spent."” Independent 9 April 1997: 4.

In-yer-face theatre: new British drama today. Anglo files: journal of English teaching. $\mathrm{n}^{\mathrm{o}} 126$ (2002), p.8-14.

SVICH, C. (2003). 'Commerce and Morality in the Theatre of Mark Ravenhill'. Contemporary Theatre Review, 13(1), 81-95.

SZONDI, P. Teoria do drama moderno. Tradução de Luiz Sérgio Repa. São Paulo: Cosacnaif, 2001.

TAYLOR, P. Theatre: Shopping and Fucking Royal Court London. The Independent, London, 3 out. 1996. Disponível em: <http://www.independent.co.uk/artsentertainment/theatre-shopping-and-fucking-royal-court-london-1356460.html $>$. Acesso em: 15 mar. 2012. 
THIELMAN, S. (2012). Theater reviews: "pool (no water)". Back Stage - National Edition, 53(20),39-40. Retrieved from https://search.proquest.com/docview/1032853616?accountid=17256

TOMLIN, L. (2013). 'Make a map not a tracing': From Pedagogy to Dramaturgy. Contemporary Theatre Review, 23(2), 120-127.

TONNIES, M. (2017). The Immobility of Power in British Political Theatre after 2000: Absurdist Dystopias. Journal of Contemporary Drama in English, 5(1), 156-172.

URBAN, K. Cruel Britannia. In: D’MONTÉ, R; SAUNDERS, G. Cool Britannia? British Political Drama in the 1990s. New York: Palgrave, 2008.

. Towards a Theory of Cruel Britannia: Coolness, Cruelty, and the Nineties. New Theatre Quarterly, London, v. 20, 4, p. 354-372, 2004. Disponível em: $<$ http://www.kenurban.org/sites/default/files/articles/NTQ_CB.pdf $>$. Acesso em: 12 jan. 2013.

WALLACE, C. Responsibility and post-modernity: Mark Ravenhill and 1990s British drama. Theory and Practice in English Studies, Brno, Masarykova univerzita, v. 4, 2005. Proceedings from the Eighth Conference of British, American and Canadian Studies.

WARNER, M (ed.). Fear of a Queer Planet: Queer Politics and Social Theory. Minneapolis: University of Minnesota Press, 1993.

WILLIAMS, R. Tragédia moderna. São Paulo: Cosac \& Naify, 2002.

WILLIAMS, R. A produção social da escrita. São Paulo: Unesp, 2014.

WIXSON, C. (2005). "In better places": Space, identity, and alienation in Sarah Kane's "Blasted". Comparative Drama, 39(1), 75-91. Retrieved from https://search.proquest.com/docview/1672991?accountid=17256

WOLF, M. (1998). World Theater: West End "Sexy Again". Variety, 371(9), K42-44.

ZIZEK, S. Violence: six sideways reflections. London: Profile, 2008.

Bem-vindo ao deserto do real!: cinco ensaios sobre o 11 de setembro e datas relacionadas. São Paulo: Boitempo, 2003. 